Prepared in cooperation with the Bureau of Reclamation

Water-Quality Modeling of Klamath Straits Drain Recirculation, a Klamath River Wetland, and 2011 Conditions for the Link River to Keno Dam Reach of the Klamath River, Oregon

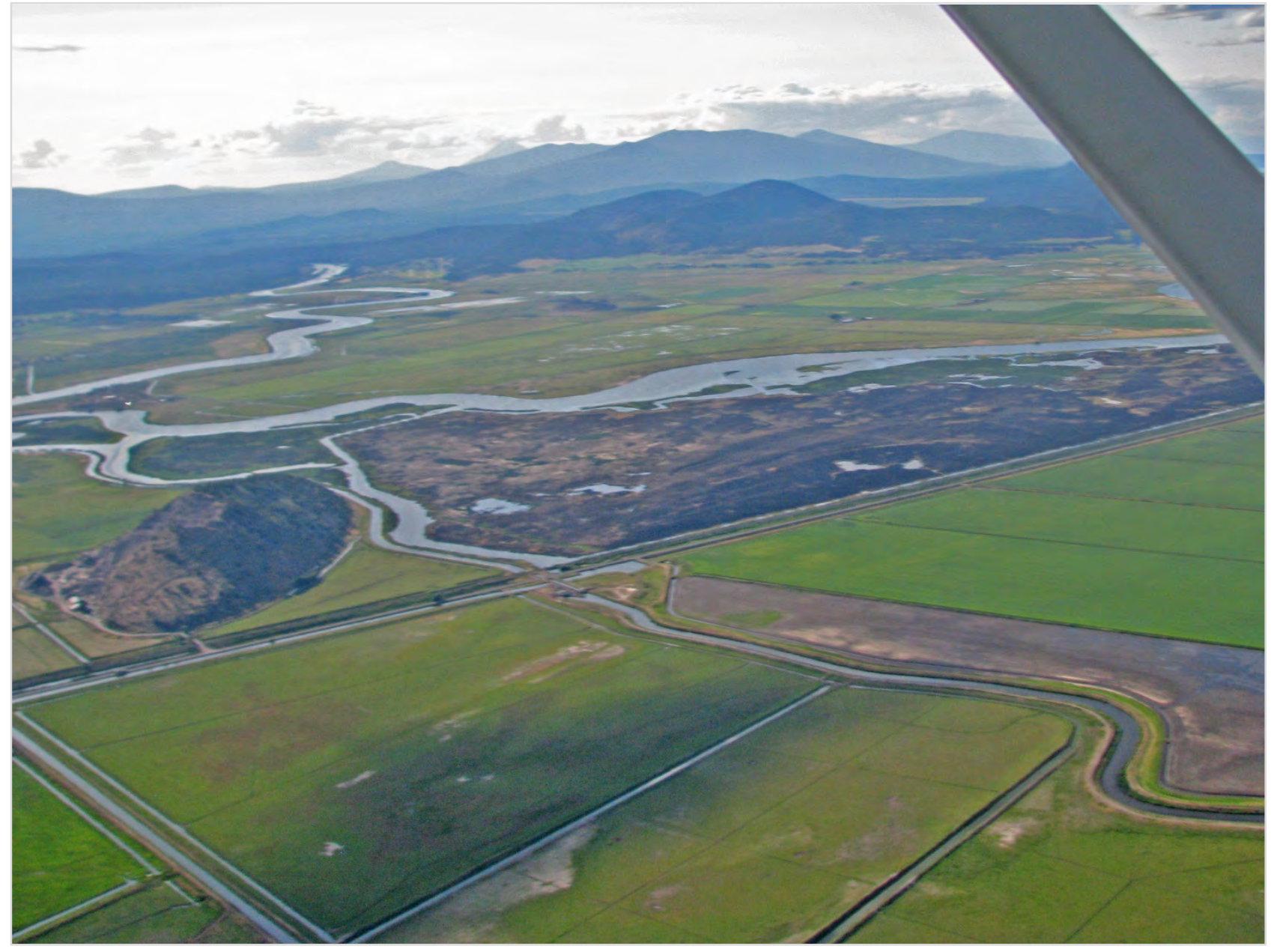

Open-File Report 2014-1185

U.S. Department of the Interior

U.S. Geological Survey 
Cover: Aerial view of the confluence of the Klamath Straits Drain and Ady Canal with the Klamath River. (Photograph by Chauncey Anderson, U.S. Geological Survey, July 8, 2009) 


\section{Water-Quality Modeling of Klamath Straits Drain Recirculation, a Klamath River Wetland, and 2011 Conditions for the Link River to Keno Dam Reach of the Klamath River, Oregon}

By Annett B. Sullivan, I. Ertugrul Sogutlugil, Michael L. Deas, and Stewart A. Rounds

Prepared in cooperation with the Bureau of Reclamation

Open-File Report 2014-1185

U.S. Department of the Interior

U.S. Geological Survey 


\section{U.S. Department of the Interior \\ SALLY JEWELL, Secretary}

\section{U.S. Geological Survey \\ Suzette M. Kimball, Director}

U.S. Geological Survey, Reston, Virginia: 2014

For more information on the USGS-the Federal source for science about the Earth, its natural and living resources, natural hazards, and the environment-visit http://www.usgs.gov or call 1-888-ASK-USGS

For an overview of USGS information products, including maps, imagery, and publications, visit $h$ ttp://www.usgs.gov/pubprod

To order this and other USGS information products, visit $h$ ttp://store.usgs.gov

Suggested citation:

Sullivan, A.B., Sogutlugil, I.E., Deas, M.L., and Rounds, S.A., 2014, Water-quality modeling of Klamath Straits Drain recirculation, a Klamath River wetland, and 2011 conditions for the Link River to Keno Dam reach of the Klamath River, Oregon: U.S. Geological Survey Open-File Report 2014-1185, 75 p., http://dx.doi.org/10.3133/ofr20141185.

ISSN 2328-0328 (online)

Any use of trade, firm, or product names is for descriptive purposes only and does not imply endorsement by the U.S. Government.

Although this information product, for the most part, is in the public domain, it also may contain copyrighted materials as noted in the text. Permission to reproduce copyrighted items must be secured from the copyright owner. 


\section{Contents}

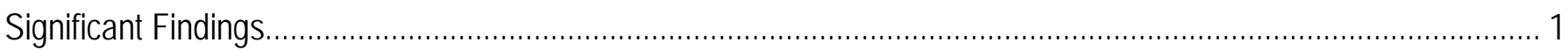

Introduction

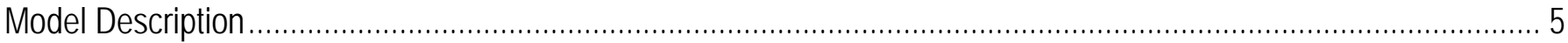

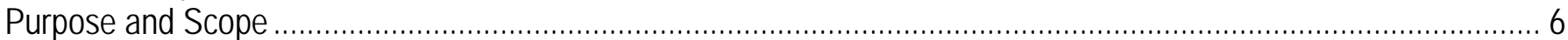

Scenario 11. Klamath Straits Drain Recirculation ...............................................................................

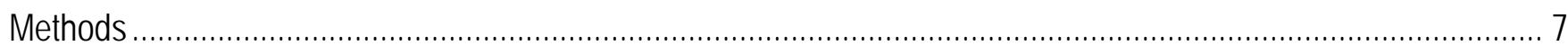

Recirculating Klamath Straits Drain Water to Ady Canal for 1-Year Periods, 2006-09 …….............................. 8

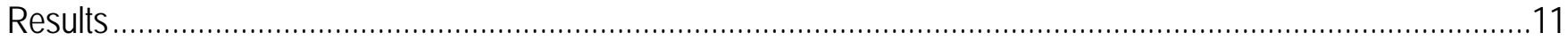

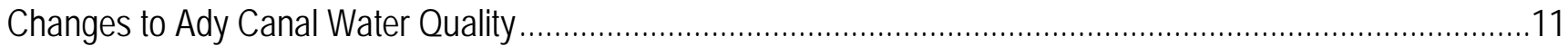

Changes to Klamath River Water Quality ...........................................................................................

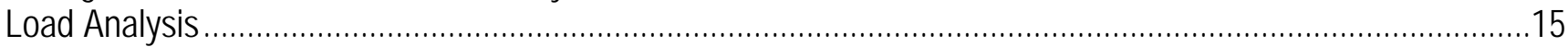

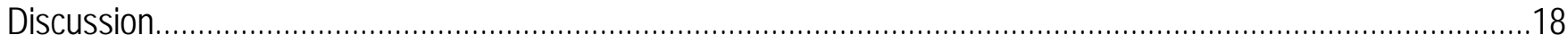

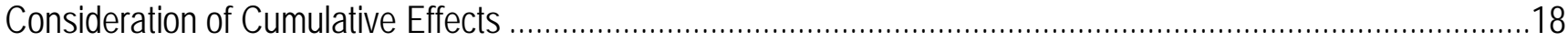

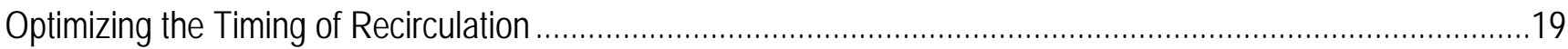

Enhancing Ady Canal Water Quality.............................................................................................

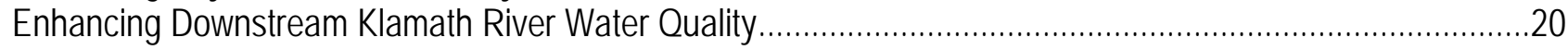

Enhancing Klamath Straits Drain Water Quality ……………

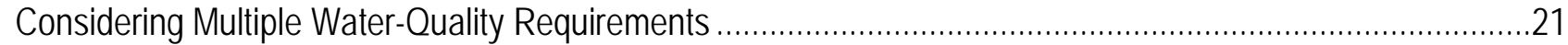

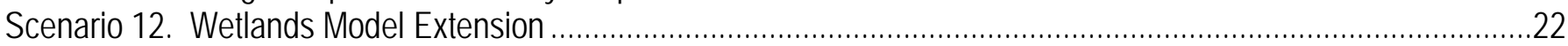

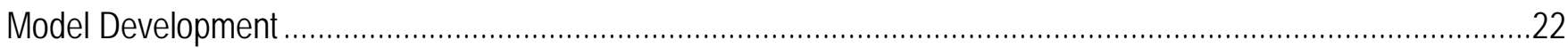

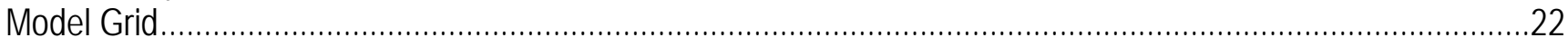

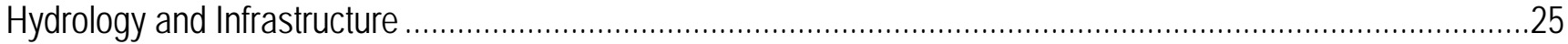

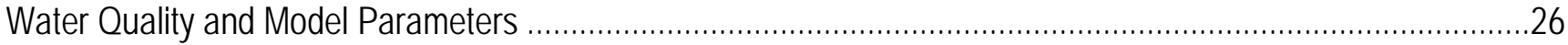

Model Boundary Conditions and Evaporation for the Wetland ....................................................................30

Model Performance .....................................................................................................................

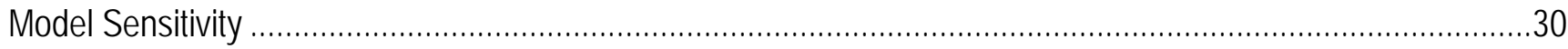

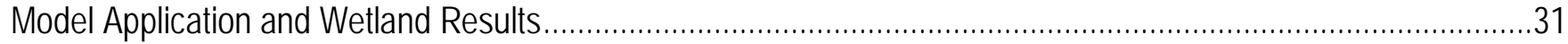

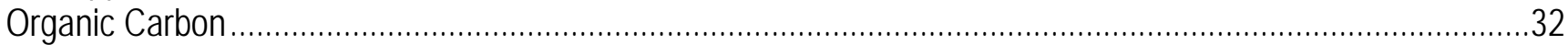

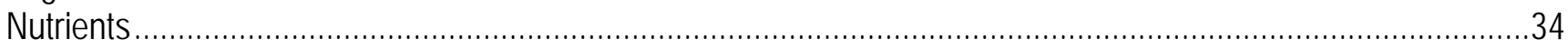

Algae and Chlorophyll a ...........................................................................................................

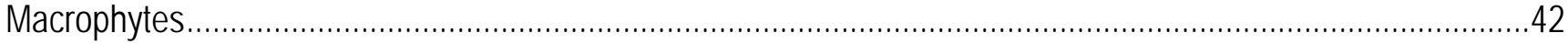

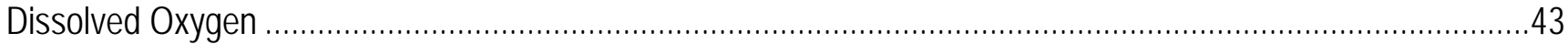

Biochemical Oxygen Demand and First Order Sediment .......................................................................44

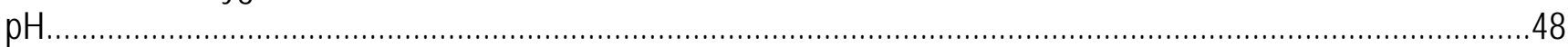

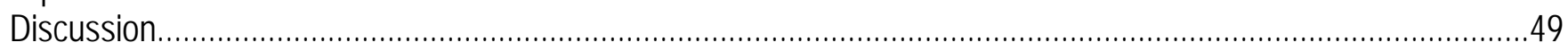

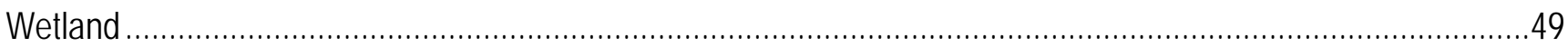

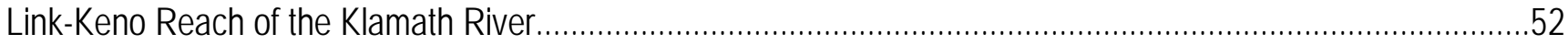

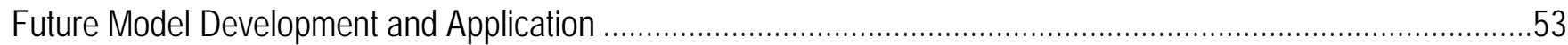

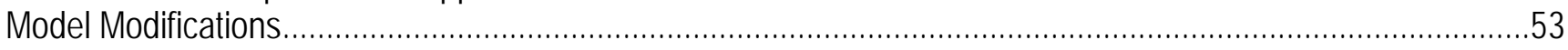

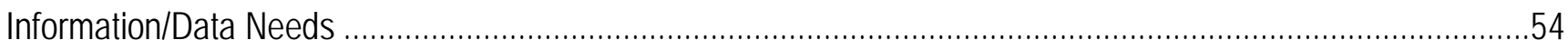

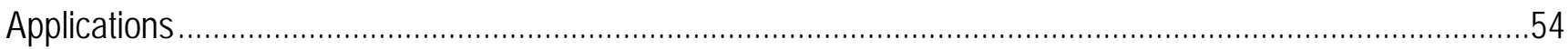

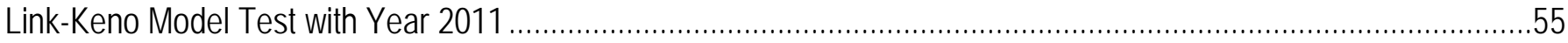

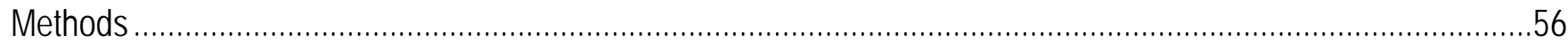

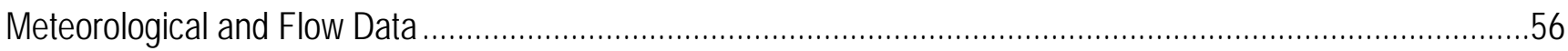

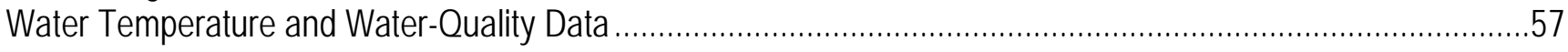




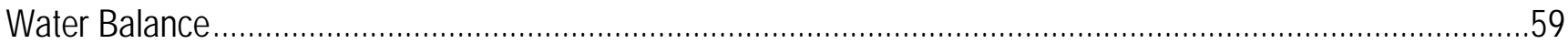

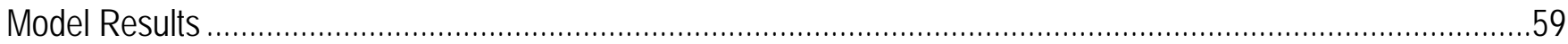

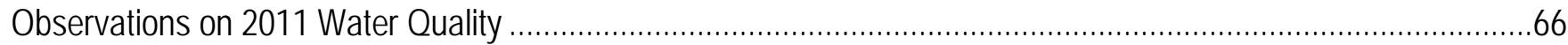

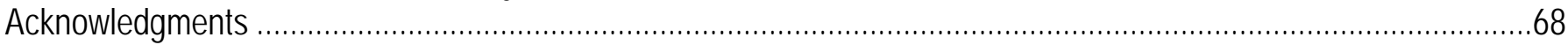

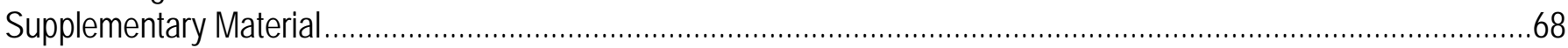

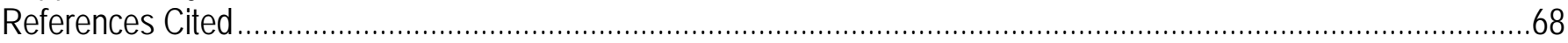

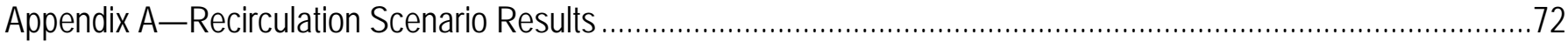

\section{Figures}

Figure 1. Map showing the study area, Klamath River, Oregon...................................................................... 4

Figure 2. Ady Canal and Klamath Straits Drain flows in the base case and flows in the recirculation scenario........... 9

Figure 3. Graphs showing modeled Ady Canal water temperature and concentration (monthly medians). Base case and recirculation scenario results and the difference between them, are shown for 2006-09................................. 12

Figure 4. Graph showing measured Klamath Straits Drain specific conductance for 2006-09. The 25th and 75th percentile values for 2006-13 are in shaded gray. Values are daily averages of hourly data................................. 14

Figure 5. Graphs showing modeled Klamath River temperature and concentration (monthly volume-average) for the reach between the Klamath Straits Drain outflow and Keno Dam.

Figure 6. Graphs showing monthly average total phosphorus loads exported out of the Klamath River through Ady Canal and imported into the Klamath River through Klamath Straits Drain in 2007, and the difference between the

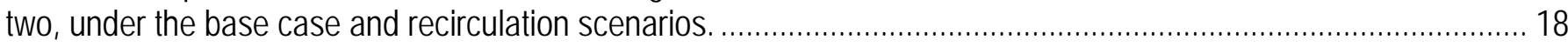

Figure 7. Map showing location of the study area showing wetland location near Miller Island............................... 23

Figure 8. Schematic showing model segments in the Link River to Keno Dam model, including the wetland branch. The first segment downstream of Link River is model segment 2 and the last model segment, at Keno Dam, is model

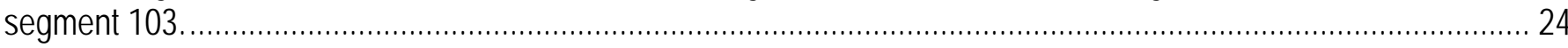

Figure 9. Schematic showing simulated wetland and plan and profile cross section with pump and weir facilities..... 25 Figure 10. Graphs showing particulate organic carbon concentrations through the wetland for the operational period (May 1-October 31) for 2006-09.

Figure 11. Graphs showing total nitrogen concentrations through the wetland for the operational period (May 1October 31) for 2006-09...

Figure 12. Graphs showing ammonia concentrations through the wetland for the operational period (May 1-October 31) for 2006-09. 35

Figure 13. Graphs showing nitrate concentrations through the wetland for the operational period (May 1-October 31) for 2006-09.

Figure 14. Graphs showing total phosphorus concentrations through the wetland for the operational period (May 1October 31) for 2006-09......

Figure 15. Graphs showing orthophosphorus concentrations through wetland for the operational period (May 1October 31) for 2006-09.

Figure 16. Graphs showing blue-green algae concentrations through the wetland for the operational period (May 1October 31) for 2006-09.

Figure 17. Graphs showing chlorophyll a concentrations through the wetland for the operational period (May 1October 31) for 2006-09. 
Figure 18. Graphs showing dissolved oxygen concentrations through the wetland for the operational period (May 1-

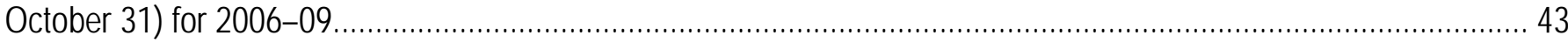

Figure 19. Graphs showing ultimate carbonaceous biochemical oxygen demand (BOD) concentrations through the wetland for the operational period (May 1-October 31) for 2006-09.

Figure 20. First-order sediment concentrations through the wetland for the operational period (May 1-October 31) for 2006-09.

Figure 21. Graphs showing pH values through the wetland for the operational period (May 1-October 31) for 200609.

Figure 22. Graphs showing particulate organic carbon (POC), labile particulate organic matter (LPOM), refractory particulate organic matter (RPOM), and total suspended solids (TSS) in the Klamath River (segment 28 at $2.0 \mathrm{~m}$ below the water surface) and through the wetland (segments 111, 118, 124; in model layer 6) for the operational period (May 1-October 31) for 2006.

Figure 23. Graphs showing dissolved oxygen, blue-green algae, particulate organic carbon, ammonia, nitrate+nitrite, and orthophosphorus concentrations at Keno Dam, model segment 103. 53

Figure 24. Graph showing dissolved oxygen concentration at Miller Island at $1 \mathrm{~m}$ depth, for 2006-12. 56

Figure 25. Graph showing daily average measured and modeled water surface elevations at Keno Dam forebay, Oregon for calendar year 2011.

Figure 26. Graphs showing measured and modeled hourly temperature and specific conductance for calendar year 2011 for sites in the Link-Keno reach of the Klamath River, Oregon.

Figure 27. Graphs showing measured and modeled hourly dissolved oxygen and pH for calendar year 2011 for sites in the Link-Keno reach of the Klamath River, Oregon.

Figure 28. Graphs showing measured and modeled water temperature, dissolved oxygen, specific conductance, and pH profiles for calendar year 2011 for the Link-Keno reach of the Klamath River, Oregon.

Figure 29. Graphs showing measured and modeled algae, nutrients, organic matter, and alkalinity for calendar year 2011 for sites in the Link-Keno reach of the Klamath River, Oregon.

Figure 30. Graphs showing measured Aphanizomenon flos-aquae and Anabaena flos-aquae biovolume at Link Dam and Miller Island in April-October 2011.

Figure 31. Graphs showing measured chlorophyll a concentrations at the southern end of Upper Klamath Lake (left) and algal biovolume at Link River for 2011 and prior years.

\section{Tables}

Table 1A. Total phosphorus, total nitrogen, and 5-day biochemical oxygen demand (BOD5) loads withdrawn from the Klamath River into the Ady Canal and to the Klamath River from the Klamath Straits Drain, as modeled in base case conditions and the recirculation scenario.

Table 1B. Total dissolved inorganic nitrogen and 5-day carbonaceous biochemical oxygen demand (CBOD5) loads withdrawn from the Klamath River into the Ady Canal and to the Klamath River from the Klamath Straits Drain, as modeled in base case conditions and the recirculation scenario.

Table 2. Potential recirculation periods to benefit water quality in Ady Canal, the Klamath River downstream of Klamath Straits Drain, and Klamath Straits Drain.

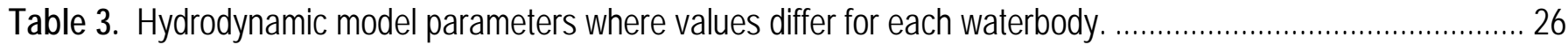

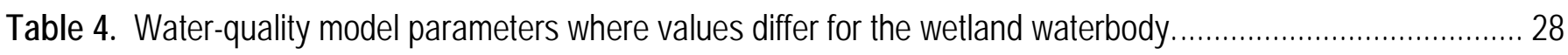

Table 5. Water-quality model macrophyte parameters where values differ for the wetland waterbody ..................... 29 
Table 6. Monthly particulate organic carbon concentrations for the simulated wetland in the Link-Keno reach of the Klamath River.

Table 7. Monthly dissolved organic carbon concentrations for the simulated wetland in the Link-Keno reach of the Klamath River.

Table 8. Monthly total nitrogen concentrations for the simulated wetland in the Link-Keno reach of the Klamath River. 38

Table 9. Monthly total phosphorus concentrations (milligrams per liter) for the simulated wetland in the Link-Keno reach of the Klamath River.

Table 10. Monthly blue-green algae concentrations (milligrams per liter) for the simulated wetland in the Link-Keno reach of the Klamath River.

Table 11. Monthly dissolved oxygen concentrations (milligrams per liter) for the simulated wetland in the Link-Keno reach of the Klamath River.

Table 12. Monthly ultimate carbonaceous biochemical oxygen demand concentrations (milligrams per liter) for the simulated wetland in the Link-Keno reach of the Klamath River.

Table 13. Monthly total suspended sediment concentrations (milligrams per liter) for the simulated wetland in the Link-Keno reach of the Klamath River.

Table 14. Location of water-quality monitors and grab-sample sites and type of data used for the development of model input files or calibration checks for the calendar year 2011 model in the upper Klamath River, Oregon........... 57

Table 15. Goodness-of-fit statistics averaged over all calibration sites for the 2011 model test. 66 


\section{Conversion Factors and Datums}

\section{Conversion Factors}

Inch/Pound to SI

\begin{tabular}{|c|c|c|}
\hline Multiply & By & To obtain \\
\hline inch (in.) & 2.54 & centimeter $(\mathrm{cm})$ \\
\hline foot $(\mathrm{ft})$ & 0.3048 & meter $(\mathrm{m})$ \\
\hline mile (mi) & 1.609 & kilometer $(\mathrm{km})$ \\
\hline acre & 4,047 & square meter $\left(\mathrm{m}^{2}\right)$ \\
\hline acre & 0.004047 & square kilometer $\left(\mathrm{km}^{2}\right)$ \\
\hline square foot $\left(\mathrm{ft}^{2}\right)$ & 0.09290 & square meter $\left(\mathrm{m}^{2}\right)$ \\
\hline square mile $\left(\mathrm{mi}^{2}\right)$ & 2.590 & square kilometer $\left(\mathrm{km}^{2}\right)$ \\
\hline cubic foot $\left(\mathrm{ft}^{3}\right)$ & 0.02832 & cubic meter $\left(\mathrm{m}^{3}\right)$ \\
\hline acre-foot (acre-ft) & 1,233 & cubic meter $\left(\mathrm{m}^{3}\right)$ \\
\hline acre-foot per day (acre-ft/d) & 0.01427 & cubic meter per second $\left(\mathrm{m}^{3} / \mathrm{s}\right)$ \\
\hline acre-foot per year (acre-ft/yr) & 1,233 & cubic meter per year $\left(\mathrm{m}^{3} / \mathrm{yr}\right)$ \\
\hline cubic foot per second $\left(\mathrm{ft}^{3} / \mathrm{s}\right)$ & 0.02832 & cubic meter per second $\left(\mathrm{m}^{3} / \mathrm{s}\right)$ \\
\hline cubic foot per day $\left(\mathrm{ft}^{3} / \mathrm{d}\right)$ & 0.02832 & cubic meter per day $\left(\mathrm{m}^{3} / \mathrm{d}\right)$ \\
\hline pound, avoirdupois (lb) & 0.4536 & kilogram (kg) \\
\hline
\end{tabular}

Temperature in degrees Celsius $\left({ }^{\circ} \mathrm{C}\right)$ may be converted to degrees Fahrenheit $\left({ }^{\circ} \mathrm{F}\right)$ as follows:

$$
{ }^{\circ} \mathrm{F}=\left(1.8 x^{\circ} \mathrm{C}\right)+32
$$

Specific conductance is given in microsiemens per centimeter at 25 degrees Celsius $\left(\mu \mathrm{S} / \mathrm{cm}\right.$ at $\left.25^{\circ} \mathrm{C}\right)$.

Concentrations of chemical constituents in water are given either in milligrams per liter (mg/L) or micrograms per liter $(\mu \mathrm{g} / \mathrm{L})$.

\section{Datums}

Vertical coordinate information is referenced to the Upper Klamath Lake Vertical Datum (UKLVD), established by the Bureau of Reclamation. For this report, the conversion is UKLVD - $1.78 \mathrm{ft}=$ National Geodetic Vertical Datum of 1929 (NGVD29).

Horizontal coordinate information is referenced to the North American Datum of 1983 (NAD 83).

Elevation refers to distance above the vertical datum. 


\section{Abbreviations and Acronyms}

BGA blue-green algae

BOD biochemical oxygen demand

BOD5 5-day biochemical oxygen demand

CBOD5 5-day carbonaceous biochemical oxygen demand

DOC dissolved organic carbon

LPOM labile particulate organic matter

ODEQ Oregon Department of Environmental Quality

POC particulate organic carbon

RPOM refractory particulate organic matter

TMDL Total Maximum Daily Load

TSS total suspended solids

USFWS U.S. Fish and Wildlife Service

USGS U.S. Geological Survey 


\title{
Water-Quality Modeling of Klamath Straits Drain Recirculation, a Klamath River Wetland, and 2011 Conditions for the Link River to Keno Dam Reach of the Klamath River, Oregon
}

\author{
By Annett B. Sullivan ${ }^{1}$, I. Ertugrul Sogutlugil'2, Michael L. Deas², and Stewart A. Rounds ${ }^{1}$
}

\section{Significant Findings}

The upper Klamath River and adjacent Lost River are interconnected basins in south-central Oregon and northern California. Both basins have impaired water quality with Total Maximum Daily Loads (TMDLs) in progress or approved. In cooperation with the Bureau of Reclamation, the U.S. Geological Survey (USGS) and Watercourse Engineering, Inc., have conducted modeling and research to inform management of these basins for multiple purposes, including agriculture, endangered species protection, wildlife refuges, and adjacent and downstream water users. A water-quality and hydrodynamic model (CE-QUAL-W2) of the Link River to Keno Dam reach of the Klamath River for 200609 is one of the tools used in this work. The model can simulate stage, flow, water velocity, ice cover, water temperature, specific conductance, suspended sediment, nutrients, organic matter in bed sediment and the water column, three algal groups, three macrophyte groups, dissolved oxygen, and $\mathrm{pH}$.

This report documents two model scenarios and a test of the existing model applied to year 2011, which had exceptional water quality. The first scenario examined the water-quality effects of recirculating Klamath Straits Drain flows into the Ady Canal, to conserve water and to decrease flows from the Klamath Straits Drain to the Klamath River. The second scenario explicitly incorporated a $2.73 \times 10^{6} \mathrm{~m}^{2}$ (675 acre) off-

\footnotetext{
${ }^{1}$ U.S. Geological Survey

${ }^{2}$ Watercourse Engineering, Inc.
}

channel connected wetland into the CE-QUALW2 framework, with the wetland operating from May 1 through October 31. The wetland represented a managed treatment feature to decrease organic matter loads and process nutrients. Finally, the summer of 2011 showed substantially higher dissolved-oxygen concentrations in the Link-Keno reach than in other recent years, so the Link-Keno model (originally developed for 2006-09) was run with 2011 data as a test of model parameters and rates and to develop insights regarding the reasons for the improved water-quality conditions.

Significant findings from this study include:

- For the years modeled, recirculation of Klamath Straits Drain flows could fulfill all of Ady Canal flow needs in spring and a portion of Ady Canal flow requirements in summer. With recirculation, and maintenance of the Link-Keno water surface elevation, there would be less withdrawal from the Klamath River by Ady Canal and less discharge to the Klamath River from the Klamath Straits Drain.

- With recirculation, Ady Canal could experience large water-quality changes in springtime, with increased specific conductance and increased concentrations of suspended sediment, particulate organic matter, nitrate, and orthophosphorus at that time of year. Water-quality changes also would be notable in summer through autumn, but changes would be smaller. 
- Recirculation would produce relatively small changes to Klamath River water quality downstream of the Klamath Straits Drain inflow. For most years and months, specific conductance and dissolved organic carbon, orthophosphorus, and nitrate concentrations would decrease in that reach. Other constituents showed more variable responses with recirculation, for example dissolvedoxygen concentrations generally increased in late winter into spring, but decreased in summer compared to the base case.

- Under base case conditions, higher total nitrogen and phosphorus loads were imported to the Klamath River by the Klamath Straits Drain on an annual basis than were exported from the Klamath River by Ady Canal. On a monthly basis, however, there were periods when Ady Canal exported more nutrients from the Klamath River than were imported by the Klamath Straits Drain.

- Recirculation decreased annual total nitrogen and phosphorus loads in both the Ady Canal and Klamath Straits Drain. The load decreases could bring the Klamath Straits Drain closer to its TMDL load allocations, but recirculation alone would likely not result in complete compliance with the TMDL.

- The Ady Canal, Klamath River, and Klamath Straits Drain would experience different water-quality effects under recirculation. Under the defined water-quality goals for these water bodies and the simulated recirculation configuration, it is difficult to pinpoint one time period where recirculation would benefit all these water bodies simultaneously.

- Findings suggest that CE-QUAL-W2 can be used to represent large, treatment scale wetlands and provide a mechanism to assess potential water-quality improvements associated with such prescriptions in the Link-Keno reach. Although challenges were identified (for example, wind mixing in the shallow, wide wetland portion of the framework; effective macrophyte representation; vegetation shading), results were consistent with previous studies and literature.

- The simulated full-scale treatment wetland decreased particulate and suspended matter on the order of $60-80$ percent, and total nitrogen and phosphorus on the order of 1040 and 10-50 percent, respectively. Ultimate carbonaceous biochemical oxygen demand decreases (about 10-30 percent) were less than literature values, but these decreases were consistent with previous estimates for the Link-Keno reach.

- Total phytoplankton (sum of all species) decreases through the wetland generally were high in the model, ranging from 30 to 90 percent. Blue-green algae showed systematic large decreases of nearly 100 percent; however, diatoms and other species occasionally increased through the wetland.

- Benefits of the simulated wetland treatment were observable downstream of the wetland return. However, improvements were modest because effects were moderated by the large river volume. Multiple wetlands of various sizes and locations capable of treating a larger fraction of the river may provide a greater benefit to downstream Link-Keno water quality.

- Testing of the model parameters, grid, and setup with year 2011 input and calibration data showed that the model performed well overall and generally reproduced the improved water-quality patterns that occurred that year. Despite that confirmation of model robustness, some specific areas were identified where model calibration could be improved, such as adjustments to the macrophyte temperature rate multipliers.

- The improved dissolved oxygen conditions observed in the Link-Keno reach in 2011 likely resulted from a combination of factors, including decreased algal loads from Upper Klamath Lake, growth and photosynthesis of Anabaena flos-aquae in mid-summer, and macrophyte photosynthesis in autumn. 


\section{Introduction}

The first $20 \mathrm{mi}$ of the Klamath River is known as the Link-Keno reach (fig. 1). Its upstream flow enters from Upper Klamath Lake through the 1-mile-long Link River; on the downstream end, the Link-Keno reach is bounded by Keno Dam. Downstream of Keno Dam, the Klamath River flows another approximately 235 mi south and west into California, terminating at the Pacific Ocean. The Link-Keno reach typically has poor water quality in summer, with areas of elevated chlorophyll $a$, ammonia, and $\mathrm{pH}$, and low dissolved oxygen. Water-quality issues are derived primarily from the settling and decay of large loads of algae that enter from Upper Klamath Lake, as well as inflows from point and nonpoint sources. Water-quality issues in this reach prompted development of a Klamath River Total Maximum Daily Load (TMDL) (Oregon Department of Environmental Quality, 2010); the nutrient portion of this TMDL was initially approved by the U.S. Environmental Protection Agency in 2012, with additional refinement to the temperature portion underway. The TMDL specifies load decreases of total nitrogen, total phosphorus, and 5-day biochemical oxygen demand (BOD5) for the nonpoint sources (Lost River Diversion Channel and Klamath Straits Drain) and for point sources (including the Klamath Falls and South Suburban wastewater treatment plants). The temperature portion of the upper Klamath River TMDL has not yet been approved, and is undergoing additional analysis. Besides the TMDL, additional efforts and plans are underway to improve water quality in the upper Klamath Basin, as documented in a recent water-quality workshop (Stillwater Sciences and others, 2013).
Water quality and flow in the Link-Keno reach of the Klamath River is linked to the neighboring Lost River Basin, directly to the east (fig. 1). The Lost River flows north from California into Oregon, turning west and then south, discharging into Tule Lake; that water is pumped westward through a ridge to the Lower Klamath National Wildlife Refuge, then through the Klamath Straits Drain into the Klamath River. The Lost River basin receives water from Upper Klamath Lake and the Klamath River through the A Canal and Lost River Diversion Channel (in summer). The North and Ady Canals move water from the Klamath River to the Klamath Project and Lower Klamath National Wildlife Refuge. Water flows in the other direction from the Lost River to the Klamath River through the Lost River Diversion Channel (in autumn through spring) and through the Klamath Straits Drain. The Lost River is also water-quality limited with a developed TMDL (Oregon Department of Environmental Quality, 2010).

Many ideas are being explored to improve water quality in the Klamath and Lost River systems. One idea under consideration is to recirculate Klamath Straits Drain water into the Ady Canal so that the water is recycled in the Klamath Project instead of discharging that water to the Klamath River (Bureau of Reclamation, 2012). Ideally, recirculation could conserve and reuse water, maintain or improve water quality, and help the Klamath Straits Drain meet its TMDL load allocation. The water-quality impacts of this recirculation on the Klamath Straits Drain, Ady Canal, and Klamath River were evaluated in this study with existing calibrated CE-QUAL-W2 models from the U.S. Geological Survey (USGS) and Watercourse Engineering, Inc. (Watercourse) (Sullivan and others, 2011, 2013a). 


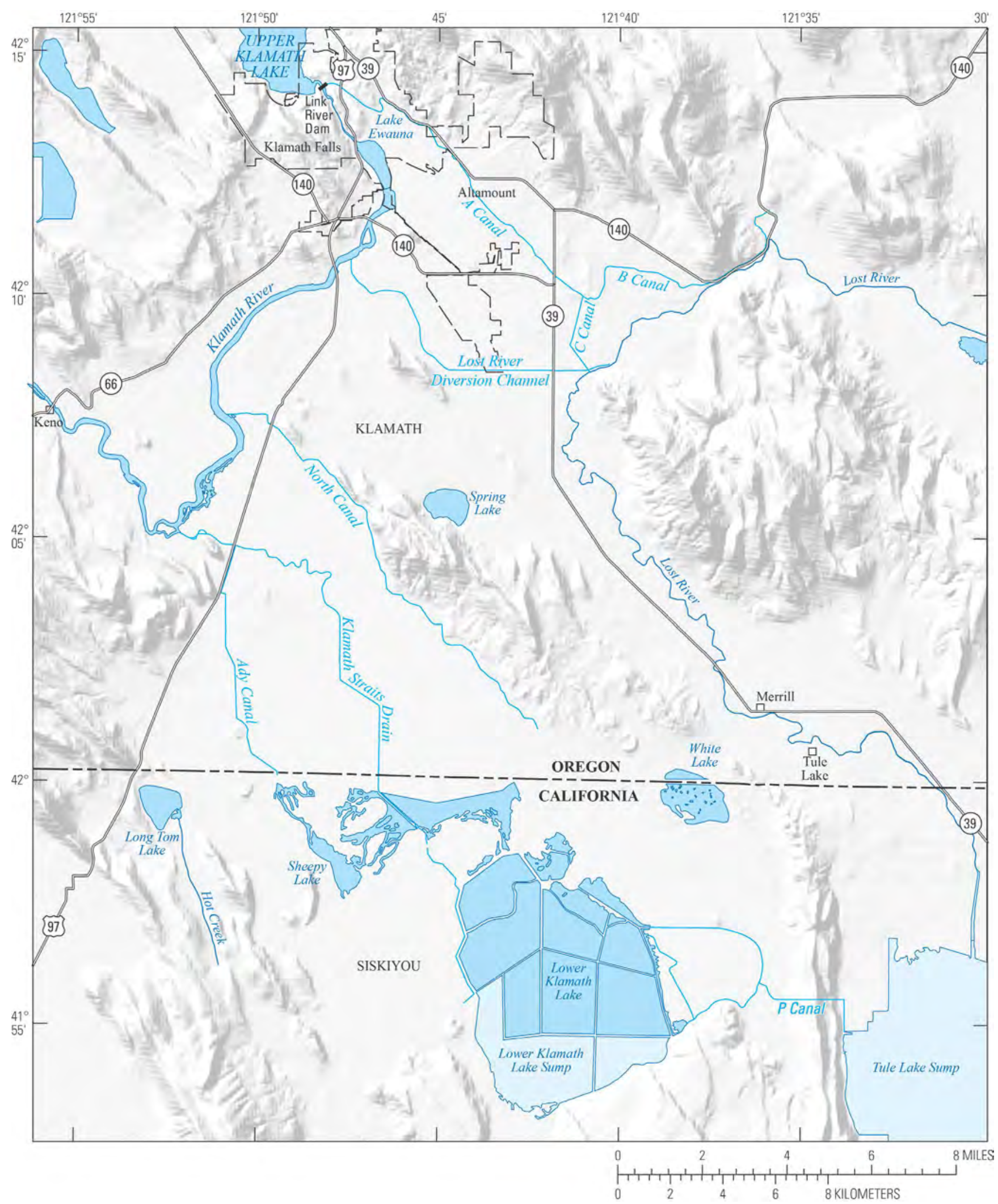

Figure 1. Map showing the study area, Klamath River, Oregon. 
The concept of treatment wetlands to improve water quality in the Link-Keno reach has been addressed in previous studies (Deas and Vaughn, 2006; Mahugh and others, 2008; CH2M-Hill, 2012; Deas and others, 2012). These studies were used by Watercourse and the USGS to guide specific CE-QUAL-W2 modeling studies addressing the potential waterquality implications of treatment wetlands (Sullivan and others, 2013b). Upon completion of that initial exploration of the use of wetlands with the USGS Link-Keno model, an explicit representation of wetlands in CE-QUAL-W2 was identified as feasible and useful. Specifically, incorporation of a wetland feature into the existing model would allow analyses of wetland performance and the associated impact on water quality of the Link-Keno reach. Although a wetland in the Miller Island area was explored in this modeling exercise, treatment wetlands at other locations and/or use of existing wetlands also could be examined, such as those in the Lower Klamath Lake National Wildlife Refuge.

The 2006-09 water-quality models used in the recirculation and wetland model scenarios have been thoroughly documented and evaluated previously (Sullivan and others, 2011, 2013a). A model is not a static tool, though, and model performance, robustness, and utility can be tested and improved when new data or process information becomes available. Year 2011 was an unusual water-quality year, with dissolved oxygen concentrations in the Link-Keno reach that remained elevated throughout the year, rather than decreasing to hypoxic or anoxic levels in summer, as is typical. Thus, the existing Link-Keno model was applied with input and calibration data from 2011 to test its performance in an unusual water-quality year, and to provide feedback on where the model could be improved to capture those kinds of conditions.

\section{Model Description}

River water quality can be affected by hydrology, weather conditions, inputs and withdrawals, chemical reactions, and biota. Mechanistic computer models such as CEQUAL-W2 (Cole and Wells, 2008) include many of these processes and are used to make predictions about the potential water-quality response to system changes. Models commonly are used in water-quality assessments for a variety of reasons, including development of TMDLs, State 401 water-quality certifications, and biological opinions. Modeling in the LinkKeno reach extends back two decades. Initial efforts by CH2M-Hill and Wells (1995) led to the first application of CE-QUAL-W2 (version 2.0) to the Link-Keno reach. Subsequent work by PacifiCorp $(2004,2005)$ for hydropower relicensing efforts used versions 3.1 and 3.2, respectively. The PacifiCorp model was used as the basis for further modeling completed for the upper Klamath River TMDL using CE-QUALW2, version 3.2 (Tetra Tech, Inc., 2009).

In an effort to improve the understanding of instream processes in this river reach and create a more accurate predictive model, the USGS, Watercourse, and the Bureau of Reclamation collaborated in a research, monitoring, and modeling study that produced a calibrated CEQUAL-W2 version 3.6 model of the Link-Keno reach for conditions that occurred in 2006-09 (Sullivan and others, 2011). This new model was based on extensive field data, with additional field research on issues of flow, suspended matter settling, and dissolved oxygen and organic matter dynamics (Sullivan and others, 2008, 2009, 2010; Poulson and Sullivan, 2010; Deas and Vaughn, 2011) to better define model parameters and rates. Subsequently, this calibrated model was updated to include macrophytes (submerged aquatic plants) and improvements to the simulation of $\mathrm{pH}$ (Sullivan and others, 2013a). These updated models were used in the scenarios described in this report. One additional update was made to the 
macrophyte initialization file to correct a formatting issue; tests showed that update to have little to no effect on model results.

This hydrodynamic and water-quality model simulates water flow, stage, velocity, ice cover, water temperature, total dissolved solids, inorganic suspended sediment, total nitrogen, particulate nitrogen, dissolved nitrate, dissolved ammonia, total phosphorus, dissolved orthophosphorus, particulate organic carbon, dissolved organic carbon, organic matter in the sediment, three phytoplankton algal types, three macrophyte types, dissolved oxygen, and $\mathrm{pH}$. Although specific conductance is not directly modeled, it can be estimated using a 0.69 conversion factor between total dissolved solids and specific conductance (Sullivan and others, 2011). The model is two-dimensional, simulating variability from upstream to downstream and from the river surface to the channel bottom. The third dimension, laterally from river bank to bank, is averaged. This type of model is suited to long, narrow, waterbodies that can thermally stratify, such as this reach of the upper Klamath River.

The models are programmed with equations and relationships to represent hydrologic and biogeochemical processes and include parameters that allow calibration. They can be used to identify controlling water-quality processes, to estimate water quality in areas without monitoring data, and to explore the water-quality effects of management options, restoration, or environmental change. It is important to remember that all models are an abstraction of nature's complexity, and that model predictions and estimates have uncertainty.

The Link-Keno model grid consists of 102 segments connected in a main branch, linked together in the direction of flow. A short secondary branch was defined for a side channel around an island in the Klamath River upstream of the Lost River Diversion Channel. Vertical grid layers in the base case model were $0.61 \mathrm{~m}$ in height. Model output can be retrieved at any segment and layer and at any time interval, often hourly.

\section{Purpose and Scope}

This report presents the results of a study to predict the potential water-quality effects of management strategies and other system changes through the application of the USGS model of the upper Klamath River from the mouth of Link River to Keno Dam. This model was used to examine possible water-quality effects of recirculating Klamath Straits Drain flows into the Ady Canal and connecting a wetland to the Klamath River near Miller Island. Both scenarios were run using existing 2006-09 models of the Link-Keno reach.

The two scenarios presented in this report (scenarios 11 and 12) continue a scenario numbering sequence from earlier reports. Previous work (Sullivan and others, 2013b) included scenarios that examined aspects of TMDL allocations and water-quality standards (scenarios 1-4), shunting particulate matter into the Klamath River (scenario 5), removing particulate algae and organic matter at Link River (scenario 6), routing river water through treatment wetlands (scenario 7), changing flow to and from the Klamath Project (scenario 8), augmenting dissolved oxygen or adding riparian shade (scenario 9), and climate change effects (scenario 10).

This report also includes a description of a calendar year 2011 model of the Link-Keno reach of the Klamath River that was constructed to test model performance in an unusual waterquality year. Development of the 2011 model provided a test of the existing model and allowed examination of factors that led to those unusual conditions. 


\section{Scenario 11. Klamath Straits Drain Recirculation}

Under current operations, the Klamath Straits Drain conveys water from agricultural areas and the Lower Klamath National Wildlife Refuge to the Klamath River, approximately 10.7 mi north and west (fig. 1). Ady Canal flows in the opposite direction, withdrawing water from the Klamath River and delivering it to agricultural lands and the Lower Klamath National Wildlife Refuge, which has permanently flooded wetlands, seasonal wetlands, agricultural lands, and upland habitat (Mayer, 2005). A water budget developed for years 2003-05 for this refuge was used to estimate that Ady Canal supplied 25 percent of refuge inflow (Risley and Gannett, 2006). That study also determined that other refuge inflows in those years included pumped flow from Tule Lake (36 percent), precipitation (21 percent), and creek inflow (18 percent).

A recent yield and water-quality improvement study appraised options for increasing efficiency and water conservation in the Klamath Project (Bureau of Reclamation, 2012). One alternative (23a) considered recirculating Klamath Straits Drain flows into the Ady Canal at Pumping Plant FF, near Highway 97 and the Klamath River. This would lessen the need to withdraw Klamath River water into Ady Canal and also decrease Klamath Straits Drain return flows into the Klamath River. Recirculation of Klamath Straits Drain flows in various configurations has been suggested previously (Danosky and Kaffka, 2002; Burt and Freeman, 2005). In addition, a 7,935 acre- $\mathrm{ft}$ annual reuse and conservation project is currently under construction between the Klamath Straits Drain and Ady Canal through the WaterSMART grant program and Klamath Drainage District. For context, as an average for the 2006-09 period, Klamath Straits Drain discharged 75,400 acre-ft/yr to the
Klamath River and Ady Canal withdrew 84,700 acre-ft/yr from the Klamath River. Thus, the WaterSMART project could potentially reduce Klamath Straits Drain and/or Ady Canal discharges and withdrawals up to a maximum of 9-11 percent.

Recirculation could affect water quality in several ways. First, water quality in the Ady Canal would change as Klamath Straits Drain water is mixed with water withdrawn from the Klamath River. Agricultural crops and refuge wildlife that receive water from Ady Canal could be affected by water-quality changes. For instance, land near Klamath Straits Drain and Ady Canal has naturally saline soils and a high water table (Cahoon, 1985), which makes these areas sensitive to irrigation water salinity. Second, changes in releases to (through Klamath Straits Drain) or withdrawals from (through Ady Canal) the Klamath River also could affect water quality in the Klamath River downstream of those locations. Finally, recirculation would decrease flow from the Klamath Straits Drain to the Klamath River, which could help the Klamath Straits Drain to meet its total phosphorus, total nitrogen, and BOD5 load allocations as specified in the Klamath River TMDL (Oregon Department of Environmental Quality, 2010).

\section{Methods}

This modeling study focused on constituents in the CE-QUAL-W2 calibrated models, including nutrients, organic matter, dissolved oxygen, and $\mathrm{pH}$. Changes in concentrations of other constituents like pesticides or trace elements were not modeled because of data and scope limitations, but they have been found to occur in some portions of the study area (Sorenson and Schwarzbach, 1991; MacCoy, 1994; Dileanis and others, 1996; Eagles-Smith and Johnson, 2012). 
Recirculating Klamath Straits Drain Water to Ady Canal for 1-Year Periods, 2006-09

This recirculation scenario considered that (a) total Ady Canal flows would remain unchanged, and (b) the maximum possible Klamath Straits Drain flow was recirculated into Ady Canal (fig. 2). When Klamath Straits Drain flows were insufficient to meet Ady Canal flow needs, water was withdrawn to the Ady Canal from the Klamath River. This occurred more frequently in summer to early winter (fig. 2). Ady Canal flow needs were greatest then, for irrigation, to meet evapotranspirative demand in the wetlands, and to flood seasonal wetlands in late autumn (Mayer, 2005).

If there was more flow in the Klamath Straits Drain than required by Ady Canal, Klamath Straits Drain flow made up 100 percent of Ady Canal flow and excess Klamath Straits Drain flows were discharged to the Klamath River (fig. 2). This was typical in late winter to spring, when Klamath Straits Drain flows were elevated due to draining of agricultural fields and seasonally flooded wetlands as well as generally higher runoff and precipitation at that time of year.

In this scenario, therefore, while total flows in the Ady Canal remained unchanged, the source of the Ady Canal flows changed from solely Klamath River water to a mix of Klamath Straits Drain and Klamath River water or entirely Klamath Straits Drain water, depending on time of year. This flow balancing also meant that the water surface elevation in the Klamath River downstream of Ady Canal and the Klamath Straits Drain was unchanged in the recirculation scenario compared to the base case. The Link-Keno reach typically is managed to maintain a near-constant water surface elevation.

This scenario was run for individual calendar years 2006, 2007, 2008, and 2009. Potential cumulative effects over time were not assessed; the water quality of Klamath Straits Drain flows to the Klamath River were assumed to have no changes from recirculation. Three aspects of water quality were examined:

1. Changes to Ady Canal Water Quality. Water quality in Ady Canal was estimated outside of the model, because the mixing location was outside of the current boundaries of the Link-Keno model grid. The concentrations of various constituents in Klamath River water withdrawn into the Ady Canal were determined from the Link-Keno model output at segment 62, the location of Ady Canal withdrawals from the Klamath River. Hourly concentrations of the same constituents in the Klamath Straits Drain were obtained from the Klamath Straits Drain model input files, which were based on measured data (Sullivan and others, 2011). Conservation of mass was assumed in determining inflow concentrations, and mixing was flow-weighted according to the proportions determined during the flow recirculation calculations described above and shown in figure 2. $\mathrm{pH}$ mixing cannot be calculated by mass balance, so the new estimated $\mathrm{pH}$ in Ady Canal was determined by using hourly total inorganic carbon, alkalinity, orthophosphorus, ammonia, dissolved organic matter concentrations, and the relevant $\mathrm{pH}$ equations (Sullivan and others, 2013a). Ady Canal water quality was predicted only at the point of mixing, not farther downstream into the Klamath Project.

2. Changes to Klamath River Water Quality. Changes to Klamath River water quality downstream of the Ady Canal withdrawal and the Klamath Straits Drain inflow, as far downstream as Keno Dam, were estimated with the Link-Keno model. This reach of the Klamath River is within the model grid boundary, so those water-quality changes can be simulated temporally and spatially, as well as considering whole-reach effects.

3. Load Analysis. Total nitrogen, total phosphorus, and BOD5 loads were determined for the Ady Canal and Klamath 
Straits Drain for the base case and recirculation scenarios (table 1a). These are the constituents for which the Klamath
Straits Drain was given annual load allocations in the Klamath River TMDL.



Figure 2. Ady Canal and Klamath Straits Drain flows in the base case (left) and flows in the recirculation scenario (right). The flow through the Klamath Straits Drain to the Klamath River is decreased in the recirculation scenario (bottom right) as some flow is routed into Ady Canal (top right). Flows are plotted as 7-day centered moving averages of daily data; raw daily data were used in modeling. 
Table 1A. Total phosphorus, total nitrogen, and 5-day biochemical oxygen demand (BOD5) loads withdrawn from the Klamath River into the Ady Canal and to the Klamath River from the Klamath Straits Drain, as modeled in base case conditions and the recirculation scenario.

[Loads are annual average daily loads, calculated using all days of the year whether or not flow occurred. Load allocations, as specified in the Klamath River TMDL, also are shown. Abbreviations: P, phosphorus; N, nitrogen; TMDL, total maximum daily load]

\begin{tabular}{|c|c|c|c|c|c|c|c|c|c|c|c|c|}
\hline \multirow[b]{2}{*}{ Calendar Year } & \multicolumn{4}{|c|}{ Total P Load (lb/day) } & \multicolumn{4}{|c|}{ Total N Load (Ib/day) } & \multicolumn{4}{|c|}{ BOD5 Load (Ib/day) } \\
\hline & 2006 & 2007 & 2008 & 2009 & 2006 & 2007 & 2008 & 2009 & 2006 & 2007 & 2008 & 2009 \\
\hline \multicolumn{13}{|c|}{ Ady Canal load, out of Klamath River } \\
\hline Base Case & 104 & 107 & 114 & 81 & 1,168 & 1,352 & 1,498 & 1,133 & 1,382 & 1,495 & 1,908 & 1,449 \\
\hline $\begin{array}{l}\text { Recirculation } \\
\text { Scenario }\end{array}$ & 52 & 59 & 62 & 41 & 576 & 760 & 822 & 606 & 761 & 884 & 1,176 & 784 \\
\hline \multicolumn{13}{|c|}{ Klamath Straits Drain load, to Klamath River } \\
\hline Base Case & 457 & 190 & 194 & 184 & 3,057 & 1,719 & 1,925 & 1,678 & 854 & 619 & 683 & 576 \\
\hline $\begin{array}{l}\text { Recirculation } \\
\text { Scenario }\end{array}$ & 291 & 61 & 66 & 78 & 1,882 & 558 & 723 & 719 & 374 & 131 & 161 & 163 \\
\hline $\begin{array}{l}\text { Klamath Straits } \\
\text { TMDL Allocation }\end{array}$ & 21 & 21 & 21 & 21 & 268 & 268 & 268 & 268 & 1,329 & 1,329 & 1,329 & 1,329 \\
\hline
\end{tabular}

Table 1B. Total dissolved inorganic nitrogen and 5-day carbonaceous biochemical oxygen demand (CBOD5) loads withdrawn from the Klamath River into the Ady Canal and to the Klamath River from the Klamath Straits Drain, as modeled in base case conditions and the recirculation scenario.

[Loads are annual average daily loads, calculated using all days of the year whether or not flow occurred. Abbreviations: DIN, dissolved inorganic nitrogen]

\begin{tabular}{|c|c|c|c|c|c|c|c|c|}
\hline & \multicolumn{4}{|c|}{ Total DIN Load (lb/day) } & \multicolumn{4}{|c|}{ Total CBOD5 Load (Ib/day) } \\
\hline Calendar Year & 2006 & 2007 & 2008 & 2009 & 2006 & 2007 & 2008 & 2009 \\
\hline \multicolumn{9}{|c|}{ Ady Canal load, out of Klamath River } \\
\hline Base Case & 387 & 542 & 593 & 474 & 1,348 & 1,447 & 1,853 & 1,405 \\
\hline $\begin{array}{l}\text { Recirculation } \\
\text { Scenario }\end{array}$ & 201 & 308 & 331 & 267 & 743 & 856 & 1,145 & 760 \\
\hline \multicolumn{9}{|c|}{ Klamath Straits Drain load, to Klamath River } \\
\hline Base Case & 565 & 388 & 415 & 315 & 818 & 593 & 656 & 555 \\
\hline $\begin{array}{l}\text { Recirculation } \\
\text { Scenario }\end{array}$ & 334 & 100 & 132 & 113 & 353 & 124 & 155 & 156 \\
\hline
\end{tabular}




\section{Results}

\section{Changes to Ady Canal Water Quality}

In this recirculation scenario, Ady Canal would undergo notable water-quality changes for some constituents, with the largest concentration changes likely in winter and spring (fig. 3; appendix table A1). At that time of year, specific conductance and suspended sediment, particulate organic carbon, dissolved organic carbon, nitrate, and orthophosphorus concentrations increased and dissolved oxygen concentrations decreased. One reason for the large changes is that Ady Canal flows typically are low in spring; thus, all or most flows could be met by recirculating Klamath Straits Drain water, with the concomitant switch in source water quality. For instance, total specific conductance in April increased in the Ady Canal from 107-188 $\mu \mathrm{S} / \mathrm{cm}$ as a monthly median in the base case to $688-825$ $\mu \mathrm{S} / \mathrm{cm}$ in the recirculation scenario, depending on year (fig. 3; appendix table A1).

Klamath Straits Drain specific conductance typically is elevated in spring (fig. 4). The high specific conductance values in spring may be due to draining of agricultural fields and seasonally flooded wetlands, which can have elevated salinity from remobilized salts (Tim Mayer, U.S. Fish and Wildlife Service, written commun., 2013). The Klamath Straits Drain has lowest specific conductance values in summer in part because low specific-conductance water is diverted into the Lost River system from Upper Klamath Lake (through the A Canal) and the Klamath River (through Lost River Diversion Channel) at that time of year.

In summer through autumn with recirculation, monthly median concentrations of dissolved organic matter, nitrate, and orthophosphorus as well as specific conductance also increased, but the increases were smaller than earlier in the year. For example, in August, the base case monthly median Ady Canal specific conductance was $112-128 \mu \mathrm{S} / \mathrm{cm}$, depending on year, and in the recirculation scenario it was estimated to be between 187 and $257 \mu \mathrm{S} / \mathrm{cm}$. For other constituents, dissolved oxygen was predicted to increase, and algae, particulate organic matter, and ammonia decreased in the Ady Canal with recirculation.

These predicted changes were estimated at the recirculation mixing location, where the Klamath Straits Drain would flow into the Ady Canal. As that water traveled south along Ady Canal, additional water-quality changes could occur. For example, particulate organic matter might settle and decay, dissolved nutrients could be taken up by aquatic plants, and dissolved oxygen concentrations could decrease because of respiration and organic-matter decay or increase from plant photosynthesis or reaeration. 

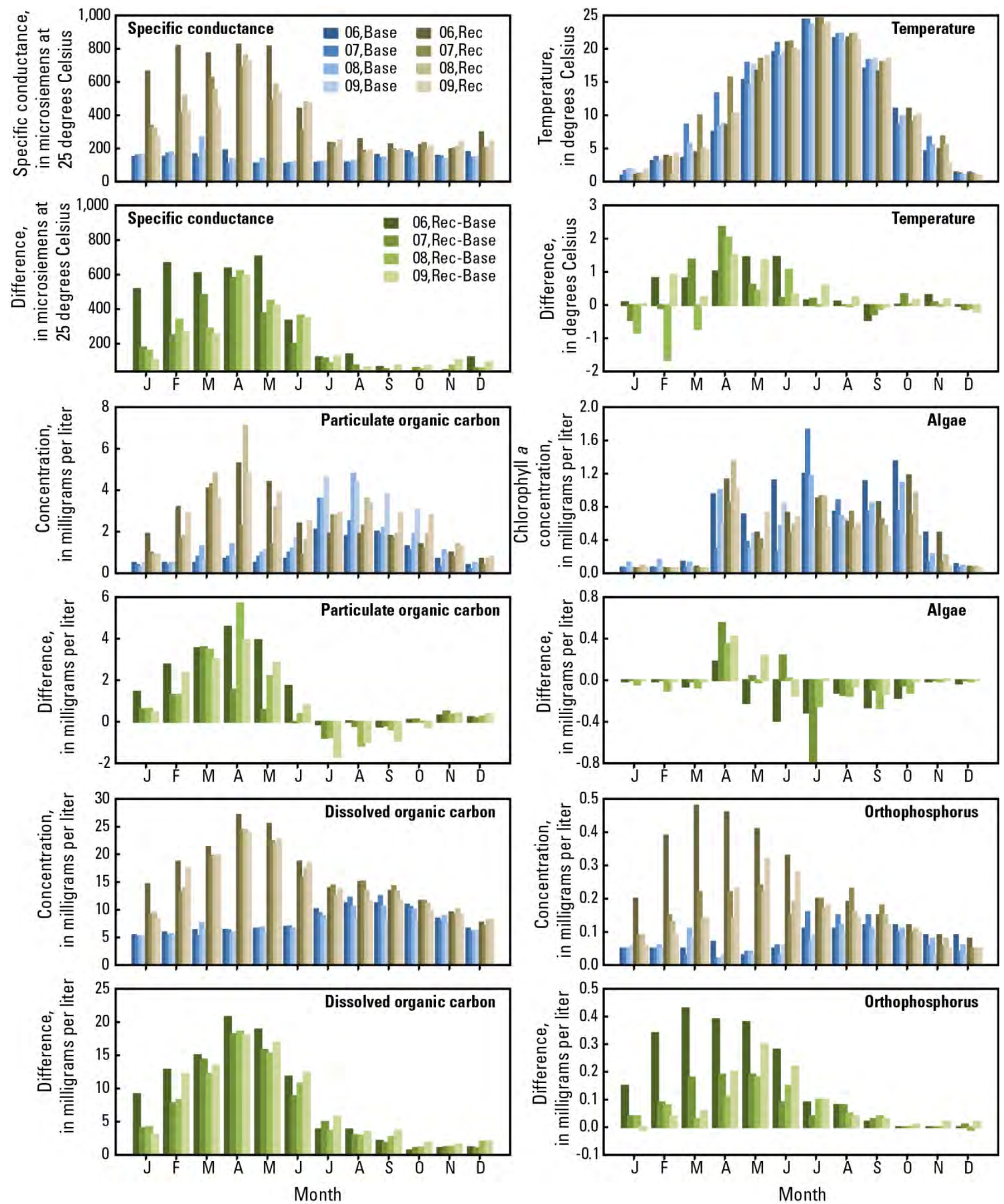

Figure 3. Graphs showing modeled Ady Canal water temperature and concentration (monthly medians). Base case and recirculation scenario results and the difference between them, are shown for 2006-09. [Abbreviations: Base, Base case; Rec, Recirculation scenario] 

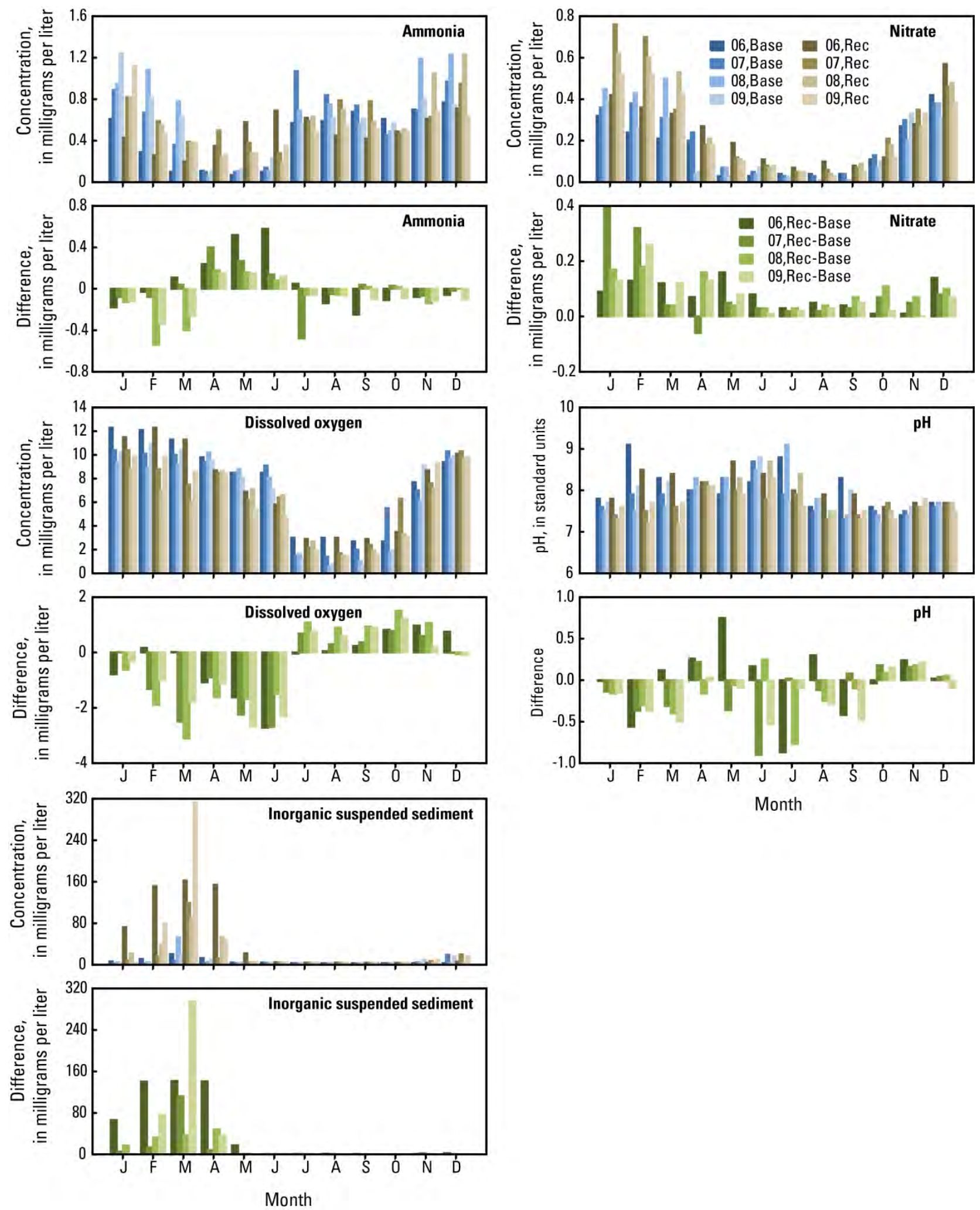

Figure 3-continued. Graphs showing modeled Ady Canal water temperature and concentration (monthly medians). Base case and recirculation scenario results and the difference between them, are shown for 2006-09. [Abbreviations: Base, Base case; Rec, Recirculation scenario] 


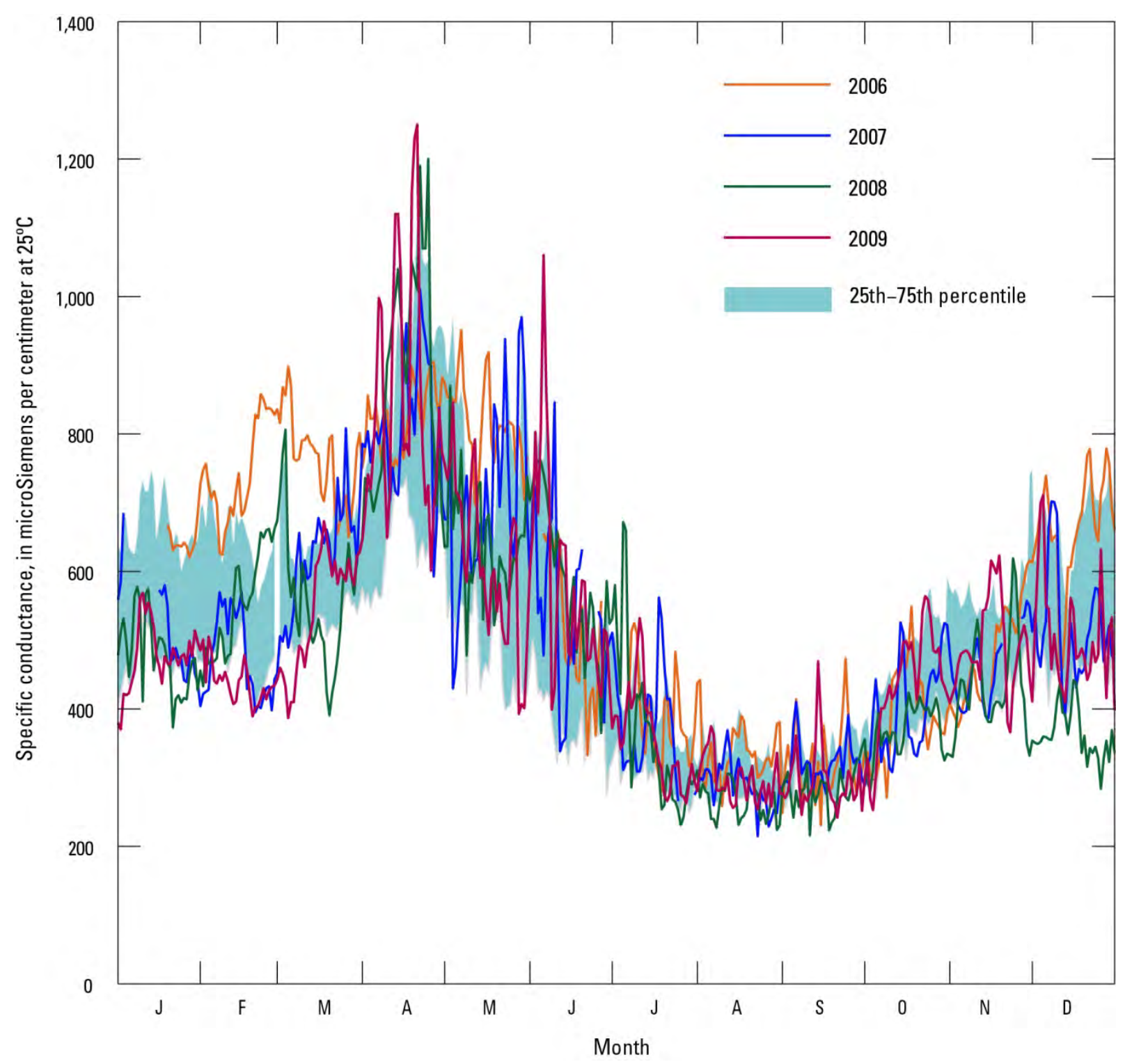

Figure 4. Graph showing measured Klamath Straits Drain specific conductance for 2006-09. The 25th and 75th percentile values for 2006-13 are in shaded gray. Values are daily averages of hourly data.

\section{Changes to Klamath River Water Quality}

In the recirculation scenario, changes to Klamath River water quality downstream of the Klamath Straits Drain inflow were minor compared to changes in the Ady Canal (fig. 5; appendix table A2). This was partly because, for most of the year, the Klamath Straits Drain contributes a relatively small proportion of the total Klamath River flow. For example, in the base case for 2007, the average daily flow at Link River was $1,165 \mathrm{ft}^{3} / \mathrm{s}$ compared to $82 \mathrm{ft}^{3} / \mathrm{s}$ in the Klamath Straits Drain. In the recirculation scenario, average daily Klamath Straits Drain flow decreased to $25 \mathrm{ft}^{3} / \mathrm{s}$, with periods of no flow (fig. 2). There were notable concentration changes though, and because this reach of the Klamath River already has poor water quality at times, small changes could be significant from a regulatory or aquatic health standpoint.

For almost all years and months, specific conductance and dissolved organic carbon, orthophosphorus, and nitrate concentrations in this scenario were predicted to decrease with recirculation in this reach of the Klamath River 
(fig. 5; appendix table A2). Other constituents showed more variable response. For instance, in late winter into spring, particulate organic carbon decreased and dissolved oxygen increased. In summer and autumn the opposite was true, with particulate organic carbon increasing and dissolved oxygen decreasing. Ammonia, $\mathrm{pH}$, and chlorophyll $a$ also increased in summer in the recirculation scenario compared to the base case.

\section{Load Analysis}

As the Klamath Straits Drain and Ady Canal flow to and from the Klamath River, respectively, they transport nutrient loads into and out of the Klamath River. Load allocations for total phosphorus, total nitrogen, and BOD5 were provided for Klamath Straits Drain in the Klamath River TMDL, and load allocations for dissolved inorganic nitrogen (DIN) and 5-day carbonaceous biochemical oxygen demand were given in the Lost River TMDL (Oregon Department of Environmental Quality, 2010). These nutrient and BOD loads were calculated from model input and outputs (tables 1a and 1b).

In the base case, annual average total phosphorus loads exported out of the Klamath River through Ady Canal were estimated at 81$114 \mathrm{lb} / \mathrm{d}$, annual average total nitrogen loads from 1,133 to $1,498 \mathrm{lb} / \mathrm{d}$, and annual average BOD5 loads from 1,382 to $1,908 \mathrm{lb} / \mathrm{d}$, depending on year (table 1a). In comparison, total phosphorus and nitrogen loads imported to the Klamath River through the Klamath Straits Drain were greater on an annual average basis, with total phosphorus loads estimated at 184 to $457 \mathrm{lb} / \mathrm{d}$, and total nitrogen loads from 1,678 to $3,057 \mathrm{lb} / \mathrm{d}$ depending on year. In contrast, the BOD5 load to the Klamath River through Klamath Straits Drain was less than that exported from the Klamath River through Ady Canal (table 1a). This is due to the fact that Klamath River organic matter had a greater proportion of labile material, such as decaying algae, compared to Klamath Straits Drain, which had a larger proportion of refractory, slow-decaying, organic matter (Sullivan and others, 2010).
Loads are calculated from flow and concentration, which both vary temporally through the year. On a monthly basis, there were periods when Ady Canal was removing more nutrients from the Klamath River than Klamath Straits Drain was contributing to the river. For example, in 2007, for the base case, exported total phosphorus loads were greater than imports to the Klamath River in July through December (fig. 6). This was due in part to the lower flows in Klamath Straits Drain at that time of year (fig. 2).

In the recirculation scenario, smaller nutrient and BOD loads were imported to and exported from the Klamath River compared to the base case loads on an annual basis (table 1a; fig. 6), because recirculation of Klamath Straits Drain waters into Ady Canal would both decrease flows to the Klamath River and decrease withdrawals from the Klamath River. With recirculation, total phosphorus loads removed from the river through the Ady Canal on an annual average basis were 41-62 lb/d, a 45-50 percent decrease compared to the base case. Total nitrogen loads removed from the river in a recirculation scenario were 574-820 lb/d, a 44-51 percent decrease compared to the base case. Total phosphorus loads to the river from the Klamath Straits Drain on an annual average basis under recirculation were 61-291 lb/d, a 36-68 percent decrease compared to the base case. Total nitrogen loads similarly were $558-1,882 \mathrm{lb} / \mathrm{d}$, a 38-67 percent decrease compared to the base case.

With decreased nutrient loads to the Klamath River, recirculation would help the Klamath Straits Drain come closer to meeting its Oregon TMDL load allocations (table 1a). Designated as a non-point source in the Klamath River TMDL, the Klamath Straits Drain was assigned load allocations of $21 \mathrm{lb} / \mathrm{d}$ of total phosphorus, 268 $\mathrm{lb} / \mathrm{d}$ of total nitrogen, and $1,329 \mathrm{lb} / \mathrm{d}$ of BOD5 on an annual average basis. Recirculation alone would likely be insufficient to meet the TMDL allocations, but it could be a management option that contributes toward that goal. 

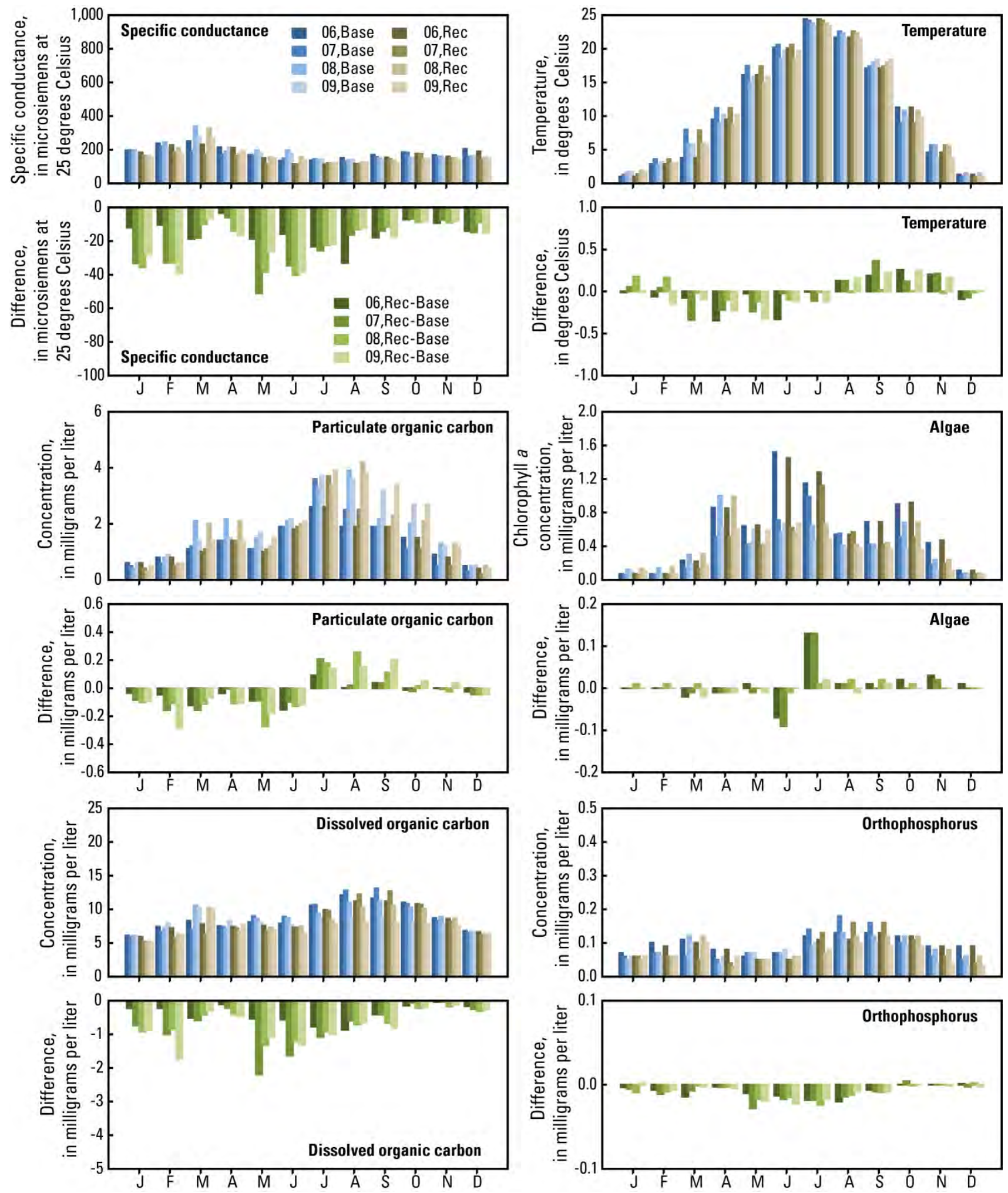

Figure 5. Graphs showing modeled Klamath River temperature and concentration (monthly volume-average) for the reach between the Klamath Straits Drain outflow and Keno Dam. Base case and recirculation scenario results and the difference between them are shown for 2006-09. [Abbreviations: Base, Base case; Rec, Recirculation scenario] 

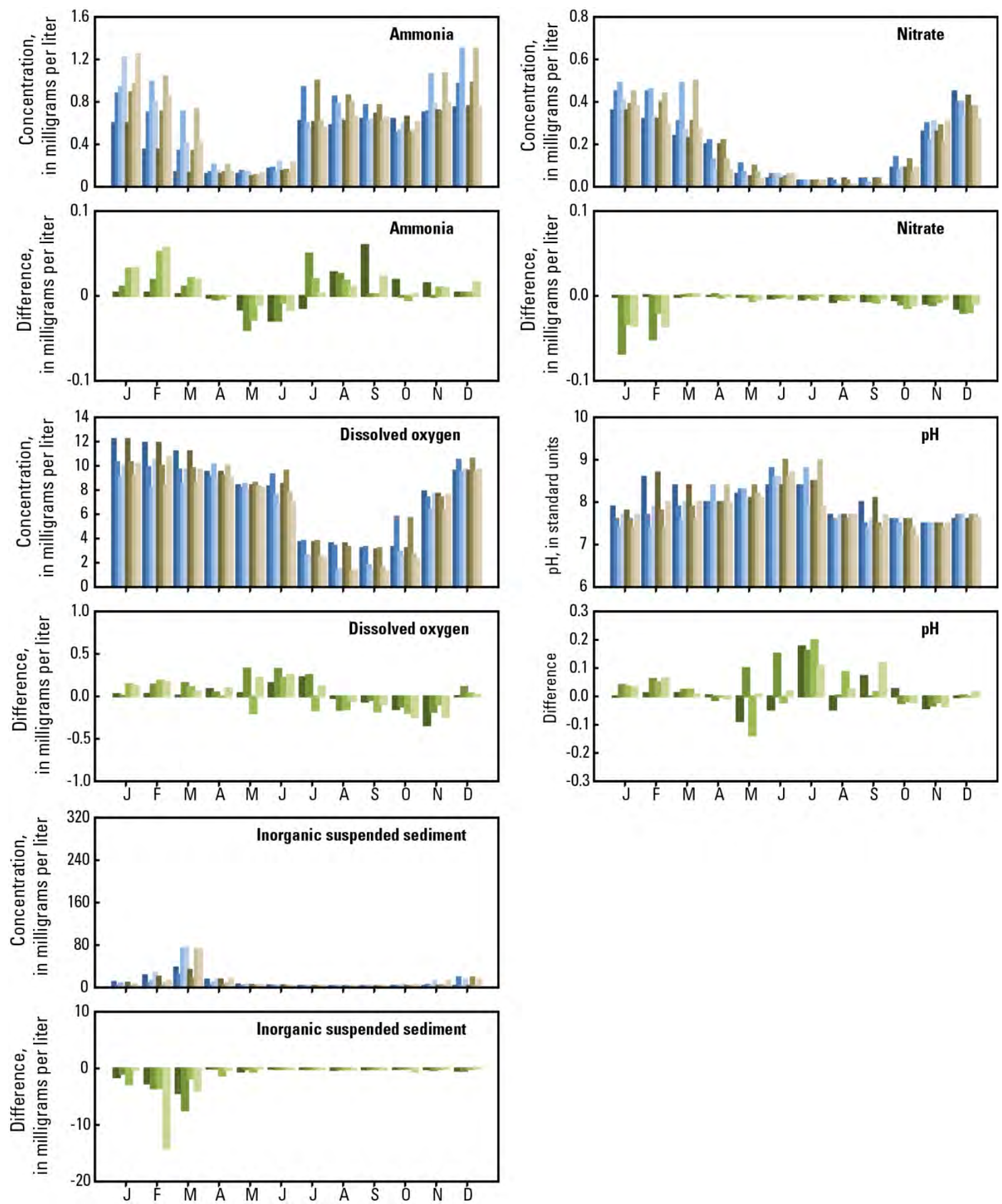

Figure 5-continued. Graphs showing modeled Klamath River temperature and concentration (monthly volume-average) for the reach between the Klamath Straits Drain outflow and Keno Dam. Base case and recirculation scenario results and the difference between them are shown for 2006-09. [Abbreviations: Base, Base case; Rec, Recirculation scenario] 

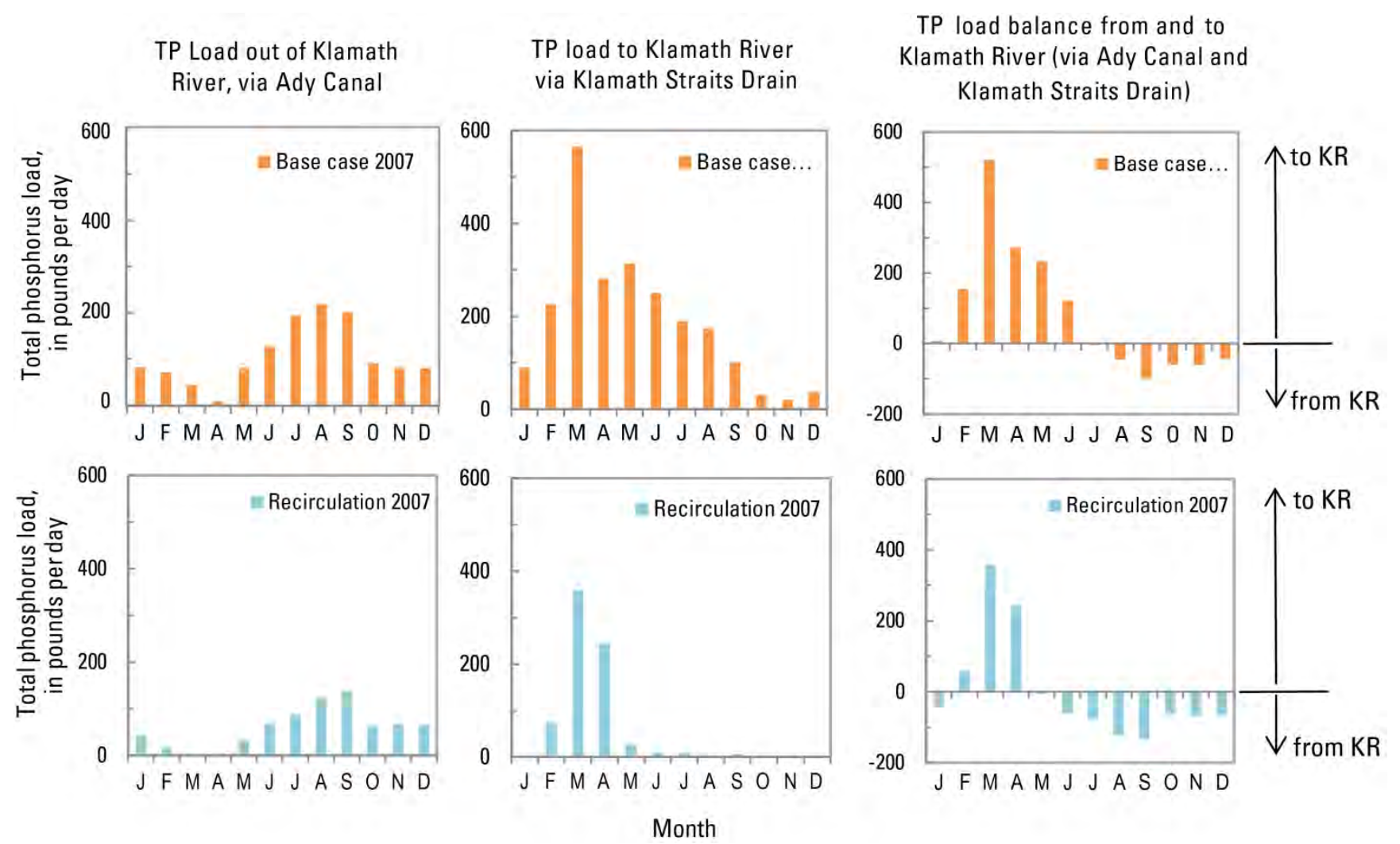

Figure 6. Graphs showing monthly average (based on hourly results) total phosphorus loads exported out of the Klamath River through Ady Canal and imported into the Klamath River through Klamath Straits Drain in 2007, and the difference between the two, under the base case and recirculation scenarios.

\section{Discussion}

\section{Consideration of Cumulative Effects}

This scenario did not consider cumulative effects of recirculation. Cumulative effects could occur if recirculation caused a constituent's concentration to increase or decrease in the Ady Canal, and then that change was carried through to agricultural fields and wetlands, so that the source of Klamath Straits Drain water might have a higher or lower concentration compared to conditions without recirculation.

For constituents that act conservatively, affected only by sources and dilution, concentrations could be expected to increase under continuous recirculation. Determining the specific level of cumulative impacts, however, is difficult to estimate. Concentration and dilution are affected by factors such as evaporation, precipitation, dissolution from soils, type of hydrologic water year or season (wet/dry), and residence time, all of which can vary spatially. For instance, Mayer (2005) found that estimated residence times within the Lower Klamath National Wildlife Refuge were 210 days for seasonal wetlands, 60 days for farmed units, and 6.6 days for permanent wetlands. In addition, other factors contribute to cumulative effects. On farmed units, the crop type and the spatial arrangements of canals and fields can affect the magnitude of a salinity increase (Mateos and others, 2000). Agricultural or refuge management also could change in response to water-quality changes, causing changes in crops or higher rates of water application, which could further change the quality of water returned to the Klamath Straits Drain. The existence or creation/management of flushing events may help to ameliorate cumulative effects. 
For nonconservative constituents such as nutrients and those affected by biogeochemical processes in addition to sources and mixing, it is even more difficult to predict concentration changes as the recirculated water travels through the Ady Canal, farm fields, and wetlands before some portion of that water returns to the Klamath Straits Drain. In addition to the source and mixing factors discussed above for conservative constituents, a multitude of biogeochemical processes could affect concentrations. For example, ammonia could be taken up by aquatic plants, algae, or crops, or transformed into other forms of nitrogen like nitrate or even nitrogen gas, in which case it is lost from the system. Fertilizer application onto fields also varies depending on crop type and time of year, thus adding another layer of required data that currently is incompletely quantified.

Although quantitative cumulative effects are difficult to predict for nutrients, Danosky and Kaffka (2002) theorized qualitatively that recirculation of drainage water generally should decrease the amount of nutrients returned to the Klamath Straits Drain, with the assumption that wetlands and agriculture both result in the net removal of nutrients. Mayer (2005) found that nutrient concentrations increased in refuge outflow, but that overall nutrient loads were decreased, with net retention of nitrogen and phosphorus by the refuge. Lost River TMDL analysis also determined that Lower Klamath National Wildlife Refuge was a nutrient sink (Oregon Department of Environmental Quality, 2010), considering its inflows from Ady Canal, Tule Lake, and other inputs. Of course, introduction and retention of nutrients in wetlands will impact the water quality of the wetlands themselves, and potentially wildlife within, as discussed below.

\section{Optimizing the Timing of Recirculation}

Acceptability of the water quality in Ady Canal, the Klamath River downstream of the Klamath Straits Drain, and the Klamath Straits Drain itself can be measured with different metrics depending on the specific water-quality goals for those waters. Each is considered separately for perspectives on how recirculation might be operated to meet those needs.

\section{Enhancing Ady Canal Water Quality}

Salinity was identified as an issue of concern in previous studies that considered Klamath Straits Drain recirculation (for example, Burt and Freeman, 2005). Elevated salinity could affect agricultural production or growth of Lower Klamath National Wildlife Refuge waterfowl forage such as willow smartweed (Persicaria lapathifolia) or sago pondweed (Stuckenia pectinata) (Tim Mayer and Dave Mauser, U.S. Fish and Wildlife Service, written commun., 2013). Salinity can be related to the total dissolved solids concentration or specific conductance; all are measures of the amount of dissolved substances in water. Additional waterquality goals for Ady Canal deliveries to the refuges could include minimizing excess nutrients and low dissolved oxygen concentrations (Tim Mayer, U.S. Fish and Wildlife Service, written commun., 2013).

In the recirculation scenario, specific conductance in Ady Canal increased most during late winter and spring. Limiting recirculation during that time of year could help limit total dissolved solids and salt accumulation within the refuge and farm units if levels were deemed unsuitable. Seedlings are most sensitive to increased salinity (Rhoads and others, 1992), another reason to limit recirculation at that time of year.

Although salinity did increase somewhat in the July-December time frame, the increase was much less, with specific conductance consistently less than $400 \mathrm{uS} / \mathrm{cm}(0.4 \mathrm{dS} / \mathrm{m})$. For most agricultural land, specific conductance values of $1.0 \mathrm{dS} / \mathrm{m}$ or less typically would not limit the growth or health of most crops.

An analysis of salinity, however, also must consider local soil characteristics, such as the leaching fraction, chemical composition, and 
other factors. The Tulana-Algoma-Teeters soil types make up much of the soil on the drained land in this area and have been described as limited for agriculture because of "wetness and excessive amounts of sodium and salt" (Cahoon, 1985). Water tables in this area typically are at a depth of 1-5 ft and soils can be inundated for long periods unless protected by dikes (Cahoon, 1985). Irrigation Training and Research determined the leaching fraction - that fraction of irrigation water that infiltrates past the root zone - in August 2004 to be 0.008 for an area bounded roughly by the North Canal, Highway 97, and the Klamath Straits Drain (Irrigation Training and Research, unpub. memorandum, 2004). This leaching fraction is extremely low, and thus could require lower salinity water than typical. In any case, recirculation plans would require consultation with agricultural experts and might require additional soil leaching measurements and monitoring of soil salinity levels.

Restricting recirculation to the JulyDecember period, instead of year-round, also could help to limit nutrients increases in Ady Canal, because the greatest increases in Ady Canal particulate organic matter, dissolved organic matter, and orthophosphorus are predicted for the January-June period in the recirculation scenario. Some nutrient concentrations could be lower in Ady Canal in summer under recirculation, including particulate organic matter, algae, and ammonia; dissolved oxygen also increased in the scenario at that time. The fact that Klamath River water quality tends to be poor in summer and was the only source of Ady Canal water in the base case implies that some recirculation of water and decreased withdrawals from the Klamath River might result in improved water quality in Ady Canal.

\section{Enhancing Downstream Klamath River Water Quality}

The Link-Keno reach of the Klamath River is considered "water quality limited" for exceeding ammonia toxicity and dissolved oxygen criteria year round and $\mathrm{pH}$ and chlorophyll $a$ in summer (Oregon Department of Environmental Quality, 2010). High water temperature is also of concern for this reach. For the years modeled, recirculation improved those constituents in the Klamath River between April and June, with water temperature and ammonia concentrations decreasing, $\mathrm{pH}$ and chlorophyll $a$ mostly decreasing, and dissolved oxygen increasing. However, the improvements were relatively small, with water temperature changing $<0.2{ }^{\circ} \mathrm{C}$, ammonia $<0.05 \mathrm{mg} / \mathrm{L}, \mathrm{pH}<0.2$, chlorophyll $a<0.5 \mu \mathrm{g} / \mathrm{L}$, dissolved oxygen $<0.4$ $\mathrm{mg} / \mathrm{L}$, as whole-reach averages.

In summer, when Klamath River water quality is of greatest concern, the model predicted that recirculation generally would increase chlorophyll $a$, ammonia, and $\mathrm{pH}$, and decrease dissolved oxygen concentrations in the Klamath River downstream. These changes occurred despite the fact that Klamath Straits Drain flows decreased and its concentration was unchanged. The reason for these changes is a result of the decreased diversion of Klamath River water into the Ady Canal that occurred in conjunction with the Klamath Straits Drain flow decrease. When Ady Canal withdrew Klamath River water in summer, it removed water that at that time of year had relatively high concentrations of algae and ammonia, high $\mathrm{pH}$, and low dissolved oxygen. Therefore, more algae would be left in the Klamath River under this recirculation scenario, some portion of which would contribute to water-quality impairment. So, while changes to loads from the Klamath Straits Drain are important, and considered in the TMDL, changes to the withdrawal of water to Ady Canal also had a small but notable effect on downstream water quality.

\section{Enhancing Klamath Straits Drain Water Quality}

One water-quality target for the Klamath Straits Drain is to decrease nutrient and BOD5 loads so that it would move towards compliance with its TMDL load allocations. Meeting the TMDL would require a greater than 80 percent decrease in total phosphorus, total nitrogen, and 
BOD5 loads from base case levels (Oregon Department of Environmental Quality, 2010; table 1a). To come close to meeting that decrease by recirculating Klamath Straits Drain flows, recirculation would have to occur year-round. In particular, recirculating in the February-June timeframe would be particularly beneficial, because of the elevated nutrient loads (and higher flows) at that time of year, with much of the nutrient load in the form of dissolved organic matter, as well as particulate organic matter, orthophosphorus, ammonia, and nitrate (fig. 3). Under maximum recirculation year-round, a 68 percent decrease would be achieved (table 1a), which is significant, but means that additional measures to meet allocations would likely need to be enacted. It is unlikely that the level of recirculation could be increased in springtime, because fields are being drained at that time of year and more water is removed from the system than brought in.

\section{Considering Multiple Water-Quality Requirements}

With the current recirculation scenario setup and water-quality goal definitions, the optimal recirculation periods to benefit Ady Canal, Klamath River, and Klamath Straits Drain did not always occur at the same time (table 2). For instance, in the spring, recirculation would be most effective at helping the Klamath Straits Drain meet its TMDL allocations. Although recirculation at that time of year could increase salinity in the Ady Canal. In summer, waterquality changes in Ady Canal would be generally moderate and recirculation would help Klamath Straits Drain come closer towards its TMDL allocations. Summertime recirculation, though, could lead to slight decreases in Klamath River water quality, largely because of decreased withdrawals of Klamath River water by the Ady Canal.

The lack of an optimum recirculation period does not mean that recirculation should not be implemented, only that careful consideration or ranking of multiple water-quality goals will need to be considered. For example, perhaps seasonal instead of annual TMDL allocations could be considered so that load decreases could be prioritized for part of the year, or perhaps improvement in one system could be determined to be of greater importance than potential degradation in the others. If recirculation were implemented, and water-quality conditions change, the management of the system also may change. For example, if higher nutrient water is returned through recirculation to agricultural fields, it is conceptually possible that there would be less need for external application of fertilizer to those fields.

There may be some flexibility in the way that the recirculation is configured as well, perhaps involving different inflows and outflows other than only the Klamath Straits Drain and Ady Canal. Flows through the system will change over time, for instance, because of regulations such as Biological Opinions (National Marine Fisheries Service and U.S. Fish and Wildlife Service, 2013) or altered conditions such as from climate change. The models serve as tools and could be rerun to analyze water-quality effects of recirculation under these types of altered conditions.

Table 2. Potential recirculation periods to benefit water quality in Ady Canal, the Klamath River downstream of Klamath Straits Drain, and Klamath Straits Drain.

[Abbreviations: TMDL, total maximum daily load]

\begin{tabular}{|l|l|l|l|}
\hline & \multicolumn{1}{|c|}{ Water quality goal } & \multicolumn{1}{c|}{ Optimal recirculation period } & \multicolumn{1}{c|}{ Avoid recirculation } \\
\hline Ady Canal & $\begin{array}{l}\text { Minimize salinity and nutrient } \\
\text { increases }\end{array}$ & July-December & January-June \\
\hline Klamath River & $\begin{array}{l}\text { Improve “water quality } \\
\text { limited” constituents }\end{array}$ & April-June & July-September \\
\hline Klamath Straits Drain & Meet TMDL load allocations & All year, especially February-June & \multicolumn{1}{c|}{-} \\
\hline
\end{tabular}




\section{Scenario 12. Wetlands Model Extension}

The implementation of a wetland within the existing CE-QUAL-W2 framework of the LinkKeno reach represents a substantial exploration and extension of modeling capabilities. This required modification of the model grid to include a new wetland branch, identification of appropriate model parameters, and testing and application of the model. This wetland was intended to represent a managed treatment feature to decrease organic matter loads and process nutrients. The wetland model was used to generally assess the potential water-quality outcomes within the wetland and in the Klamath River below the wetland. The approximately $2.73 \times 106 \mathrm{~m}^{2}$ (675 acres) wetland was located in the Miller Island area of the Klamath River, where previous work had identified potential wetland locations. Future modeling could examine the effect of routing water through other wetland locations, including existing wetlands.

Wetland operations were assumed to extend from May 1 through October 31, which is a primary growing season for wetland plants in the upper Klamath Basin. To provide the necessary flow and actively manage the wetland, a pump was assumed to convey water into the wetland near the upper end of the Miller Island Wildlife Area, and a weir was placed at the lower end of the wetland to control the wetland's water surface elevation.

Most analytical wetlands models are reaction rate models and represent the system as a completely mixed system (see Kadlec and Wallace, 2009). A variety of two-dimensional depth-averaged numerical models have been applied to wetlands, largely focusing on hydrodynamics (Roig, 1995; DePaoli, 1999; Langevin and others, 2002). Additional detail and simulation of water-quality dynamics within the wetland using the two-dimensional CE-QUALW2 is useful to provide insight into design and efficacy of potential treatment.

\section{Model Development}

Model Grid

The geometry of the wetland feature was developed based on previously identified potential long-term wetland sites and desired design features (Mahugh and others, 2008; CH2M-HILL, 2012; Deas and others, 2012). Stable water surface elevations in the Link-Keno reach during the critical summer period allowed a reasonable structured connection to be modeled that moves river water into shallow wetland areas adjacent to the Klamath River with a return to the river downstream. Because treatment wetlands are often designed as a series of interconnected cells, the geometry of such a system can be represented well in CE-QUAL-W2 and provides more detail than the reaction rate wetlands models typically used (Kadlec and Knight, 1996; Kadlec and Wallace, 2009). For this study, the wetland area in Miller Island on the southern bank of the river between the Lost River Diversion Channel and North Canal was selected as the location of the simulated treatment wetland (fig. 7). 


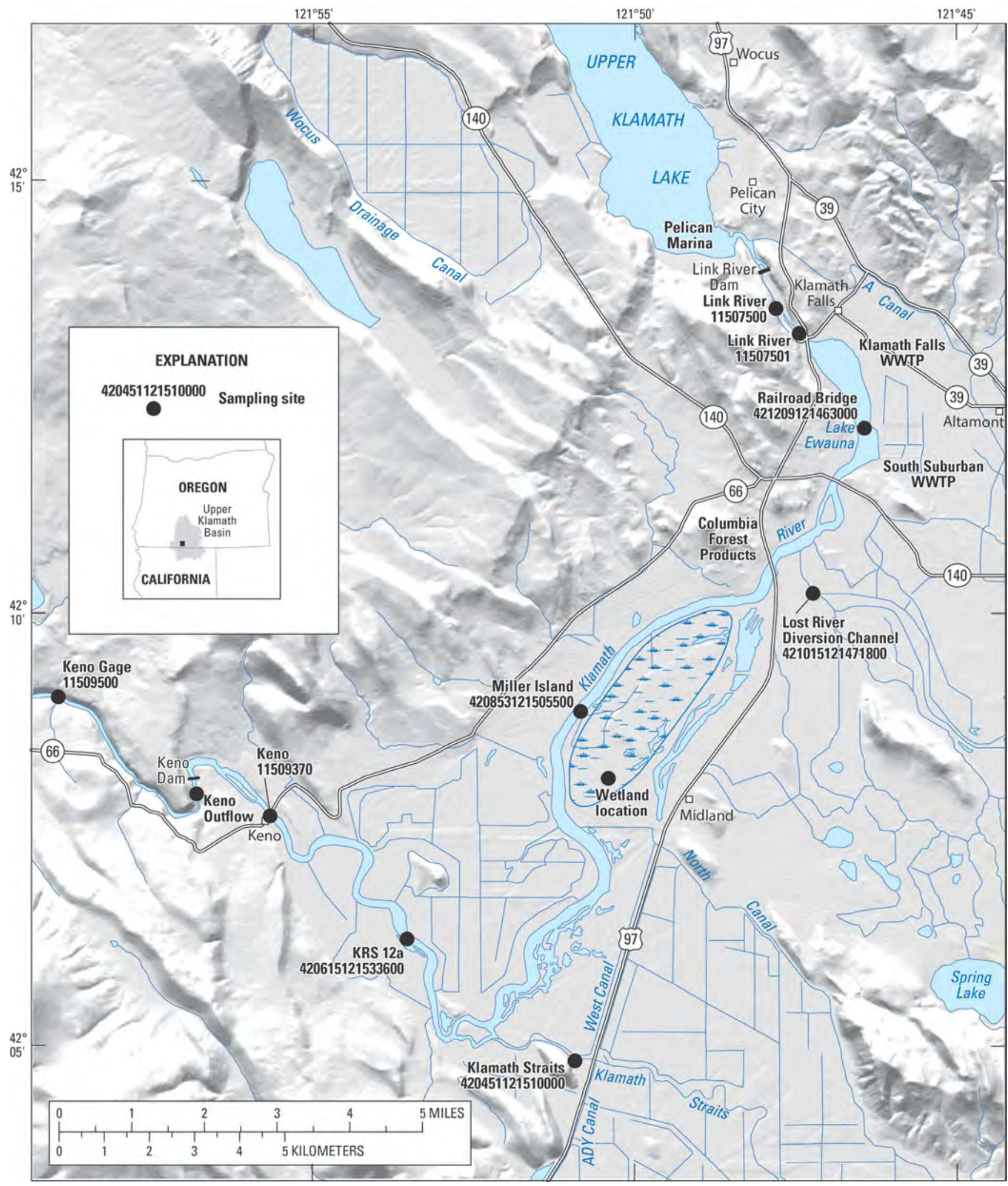

Figure 7. Map showing location of the study area showing wetland location near Miller Island. 
Sixteen model segments of average length $312.5 \mathrm{~m}(1,025 \mathrm{ft})$ were used to depict the wetland. Segments 111 through 123 were $300 \mathrm{~m}$ in length, and segments 124, 125, and 126 had lengths of 350,400 , and $350 \mathrm{~m}$, respectively, for a total distance of 5,000 m. Additional grid layers were added to the mainstem model branch to match the topmost layer in the wetland representation. Subsequently, the layer height for the wetland branch was set uniformly to $0.30 \mathrm{~m}$ $(1 \mathrm{ft})$-one-half the thickness of the mainstem layers. Decreased grid layer thickness in the wetland was desired because wetland depths were considerably less than mainstem depths, and ultimately the decreased layer heights led to a more stable model in the wetland branch. The entire river model grid was regenerated with a uniform $0.30 \mathrm{~m}$ layer height in the topmost eight layers to correspond with those in the wetland. Implications of grid resolution are discussed in greater detail below. Besides the transition segments to and from the wetland, which varied in width from $250 \mathrm{~m}(820 \mathrm{ft})$ to $600 \mathrm{~m}(1,969 \mathrm{ft})$, each main wetland segment had a width of 1,500 $\mathrm{m}$ (1,969 ft) (fig. 8), considerably wider than the adjacent Klamath River. This width led to a wetland residence time of approximately 4-5 days, providing sufficient time for treatment.
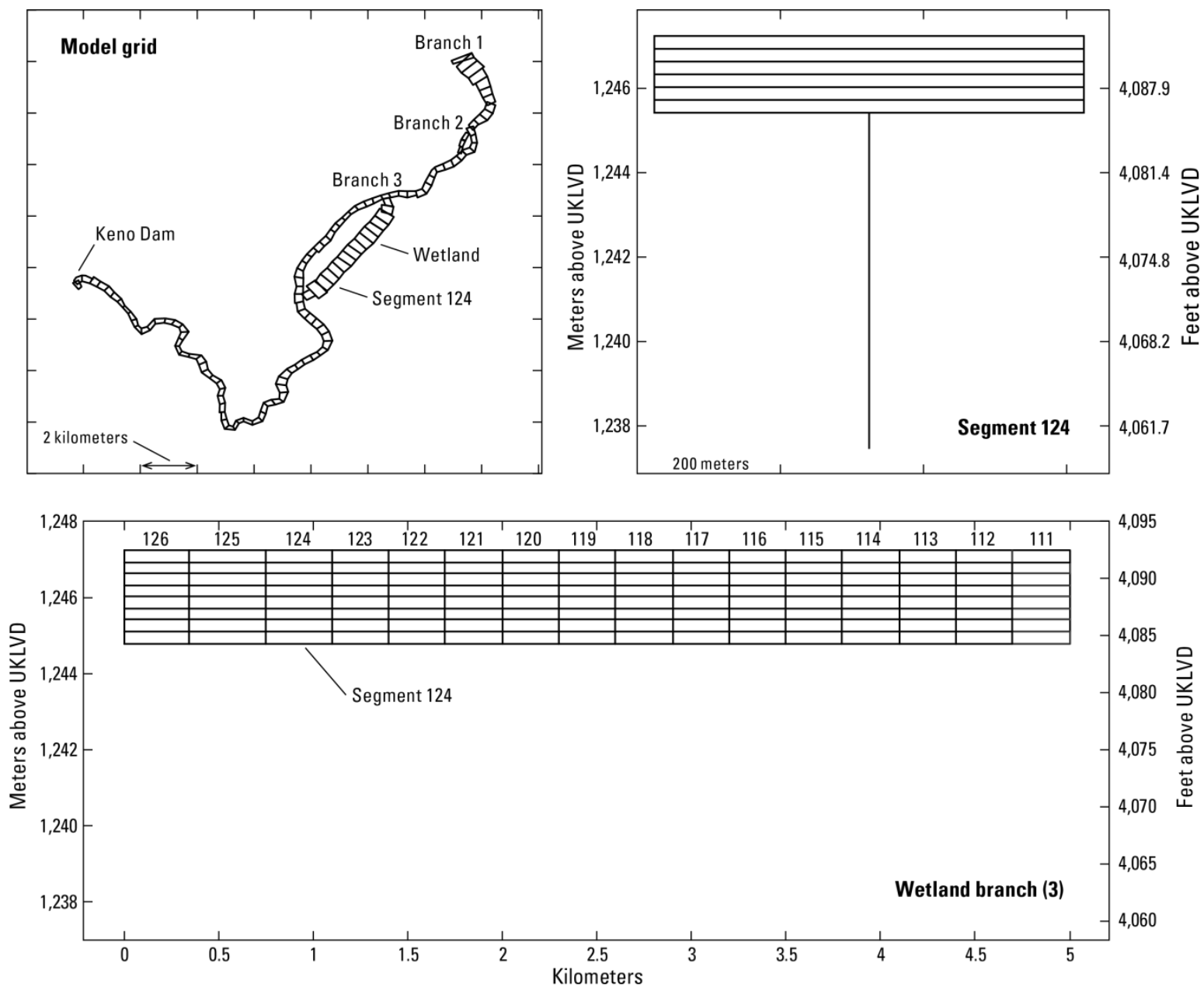

Figure 8. Schematic showing model segments in the Link River to Keno Dam model, including the wetland branch (top left). The first segment downstream of Link River is model segment 2 and the last model segment, at Keno Dam, is model segment 103. In the wetland model scenario, water is pumped from the Klamath River at segment 28 into the wetland and returns to Keno Reservoir in segment 45. A typical cross section (top right; segment 124) and profile of the wetland branch (bottom) also are shown. 
Hydrology and Infrastructure

Hydrologic representation of the wetland took advantage of the control structure options in CE-QUAL-W2 for conveying water into the wetlands, through the identified wetland configuration, and back to the Klamath River (that is, representation of weirs, spillways, gates, pipes, pumps [Cole and Wells, 2008]). These structures and their use in the model representation of the wetland are shown in figure 9.

Key features of the wetland model grid included:

- The wetland site was integrated with the original reservoir grid (Sullivan and others, 2013b) as a distinct waterbody, enabling the assignment of unique values for wetlandspecific model parameters. Most of the simulated hydrodynamic parameters and water-quality constituents for the wetland were identical to those simulated in the river.

- A pump stationed at segment 28 of the river model conveyed water into the wetland at the most upstream wetland segment (segment $111)$, at a fixed rate of $5.66 \mathrm{~m}^{3} / \mathrm{s}\left(200 \mathrm{ft}^{3} / \mathrm{s}\right)$ from May 1 through October 31 .

- A spillway was placed at the end of the downstream-most wetland segment to prevent

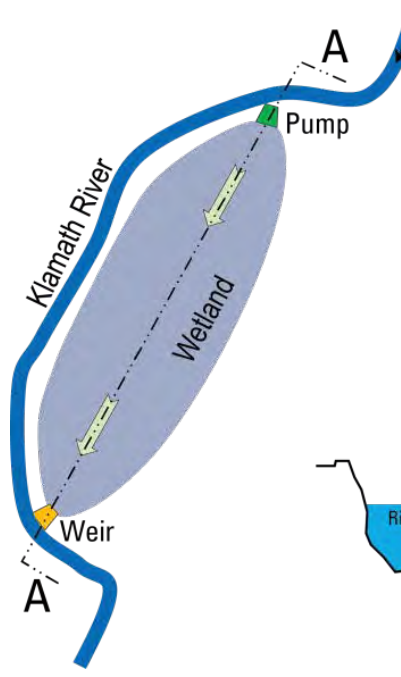

backflow from the river into the wetland and to maintain a stable water surface elevation and depth in the wetland. The crest elevation of the spillway at segment 126 was set to $1,246.22 \mathrm{~m}(4,088.60 \mathrm{ft})$.

- No other inflows or outflows occurred in the wetland branch, with the exception of evaporation (that is, no distributed tributary to represent miscellaneous accretions and depletions).

- Besides the most downstream segment where the spillway was stationed, bed elevation within the wetland was set to $1,245.40 \mathrm{~m}$ $(4,085.91 \mathrm{ft})$. This elevation is higher than the maximum daily averaged water surface elevation measured in the river during 2006 09.

- A mild slope of 0.00004 was assigned to the wetland, but results with a 0 slope were essentially identical.

Several parameters associated with the model's hydrodynamics were set to different values for the wetlands (table 3 ). The wind sheltering coefficient (WSC) was set to a lower value considering the effect of dense vegetation within the wetland (Poindexter and Variano, 2013). Similarly, the bottom friction coefficient (FRICTC) was set to a higher value for the same reason. 
Table 3. Hydrodynamic model parameters where values differ for each waterbody.

[Abbreviations: WB1, waterbody 1 (river); WB2, waterbody 2 (wetland); m, meter]

\begin{tabular}{|l|c|c|l|}
\hline \multicolumn{1}{|c|}{ Parameter } & WB1 & WB2 & \multicolumn{1}{c|}{ Description } \\
\hline WSC & 1.0 & 0.19 & Wind sheltering coefficient, dimensionless \\
\hline FRICTC & 0.02 & 0.08 & $\begin{array}{l}\text { Bottom friction-Manning's roughness coefficient, } \\
\text { dimensionless }\end{array}$ \\
\hline EBOT & $1,236.87$ & $1,237.48$ & Bottom elevation of waterbody, $\mathrm{m}$ \\
\hline SLOPE & 0.0 & 0.00004 & Waterbody bottom slope, dimensionless \\
\hline
\end{tabular}

\section{Water Quality and Model Parameters}

Water quality and model parameters from previous studies, including areas upstream of the study site (for example, Wong and Hendrixson, 2011; Wong and others, 2011) and the literature were used to develop appropriate wetland representations in the model. The same constituents and processes simulated in the LinkKeno river reach (zero- and first-order sediment processes, multiple algal species, macrophytes, etc.) were also simulated in the wetland. Loads and water quality of diversions to, conditions within, and return flows from the wetland were assessed to determine the potential implications of the wetlands on water quality within the wetlands as well as in the Link-Keno reach.

In this scenario, the parameter values for the Link-Keno river reach from previous studies (Sullivan and others, 2011, 2013a) were retained. For the wetland reach, some of the model parameters were changed according to literature values and through the calibration process. Because the wetland site selected for this study was not a current active wetland, no site-specific field data were available to test and calibrate the model. Final model parameters, for both the river (unchanged) and those which were modified for the wetland reach, are included in table 4. Model parameters for macrophytes are addressed separately in table 5 .

Light extinction was decreased assuming that dissolved organic carbon (DOC) concentrations would decrease through the wetland (Pinney and others, 2000), and overall the modest depth of the simulated wetland (typically $<1 \mathrm{~m}$ ) led to model results that were moderately insensitive to light extinction, consistent with results from Carpenter and others (2009). Organic and inorganic light extinction also was decreased assuming macrophyte shading was the dominant light extinction process, and the EXM parameter (table 5) was increased slightly to capture that effect (Brix, 1997).

Refractory organic matter decay rates were increased slightly to accommodate potential photolytic impacts (Wetzel and others, 1995) on recalcitrant organic carbon in wetlands where a high area to volume environment exists (Robarts and Waiser, 1998; Ramash Reddy and De Laune, 2008; Jasper and Sedlak, 2013). The particulate organic matter settling rate was increased to accommodate the quiescent nature of the wetland and vegetative components that would promote settling, and the upper temperature range for organic matter decay was increased to accommodate potentially warmer water temperatures of the wetland.

The phosphorus sediment release rate under anoxic conditions (PO4R) was set to a lower value because wetland soils are known to have a greater ability to retain phosphorus (Dunne and others, 2006) while the ammonia sediment release rate under anoxic conditions (NH4R) was assigned a higher value considering that high rates of net ammonium diffusion from the 
rates of net ammonium diffusion from the wetland sediments may occur (O'Brien and others, 2012). The ammonia nitrification rate (NH4DK) was increased to reflect wetland removal of ammonia (Crites, 2006; Mitsch and Gosselink, 2007) and accommodate the shallow nature of the system and potential depth dependent nitrification rates (Pauer and Auer, 2009). The nitrate denitrification and loss rate parameters (NO3DK and NO3S) were modified based on the high $\mathrm{pH}$ and high concentrations of ammonia and organic matter in the wetland areas (Kadlec and Wallace, 2009).

The initial sediment organic-matter concentration (SEDCI), as well as initial conditions for most parameters, were set to low values in the wetland to be consistent with a dewatering period and freezing of standing water during winter-processes that are beyond the scope of this initial investigation.

While the lake reaeration equation (Cole and Wells, 2008; reaeration equation 14) was used for the river, an estuarine option was selected for the wetland based on the wide, shallow, and relatively quiescent conditions. In this case, option zero was selected, wherein the model would select an approach based on calculated depth and velocity. This approach provided a means to accommodate shallow, low velocity conditions. Both reaeration options were assessed and simulated results were similar
In this scenario, a specific macrophyte type for the wetland was assigned, in addition to the three original macrophyte types assigned for the river reach (Sullivan and others, 2013a). The main purpose of assigning a different macrophyte type for the wetland (termed "Mac1") is to achieve spatially and temporally homogeneous and dense macrophytes within the wetland. This approach assumed a representative assemblage of wetland plants, a necessity because of a lack of site-specific data for an engineered treatment wetland. Model parameter values generally were consistent with the macrophyte representation in the river reach, and only a few parameters were markedly different (table 5). Exceptions include the threshold of macrophytes required to move (grow) into subsequent layers (MEMP) and the maximum macrophyte concentration (MMAX). These parameters were decreased because of the refined vertical grid of the wetland (decreased layer thickness) and the overall shallow nature of the wetland. Additional discussion of grid resolution and potential impacts on macrophyte growth are discussed below. For this scenario, the homogeneous macrophyte group was assumed to obtain all nutrients from the water column. Parameters that addressed drag (CDDRAG) and fraction of the macrophyte area impeding flow (ANORM) were increased to represent a highly vegetated wetland. 
Table 4. Water-quality model parameters where values differ for the wetland waterbody.

[Abbreviations: WB1, waterbody 1 (river); WB2, waterbody 2 (wetland); ${ }^{\circ} \mathrm{C}$, degrees Celsius; g, gram; g/m², gram per square meter; $\mathrm{m}$, meter; $1 / \mathrm{d}$, per day; $1 / \mathrm{m}$, per meter; SOD, sediment oxygen demand]

\begin{tabular}{|c|c|c|c|}
\hline Parameter & WB1 & WB2 & Description \\
\hline EXH2O & 1.217 & 1.017 & $\begin{array}{l}\text { Light extinction coefficient for water and dissolved } \\
\text { constituents, } 1 / \mathrm{m}\end{array}$ \\
\hline EXSS & 0.167 & 0.100 & Light extinction due to inorganic suspended solids, $1 / \mathrm{m}$ \\
\hline EXOM & 0.147 & 0.100 & Light extinction due to organic suspended solids, $1 / \mathrm{m}$ \\
\hline BETA & 0.45 & 0.40 & $\begin{array}{l}\text { Fraction of solar radiation absorbed at water surface, } \\
\text { dimensionless }\end{array}$ \\
\hline RDOMDK & 0.0005 & 0.001 & Refractory dissolved organic matter decay rate, $1 / \mathrm{d}$ \\
\hline LRDDK & 0.002 & 0.003 & $\begin{array}{l}\text { Labile to refractory dissolved organic matter conversion } \\
\text { rate, } 1 / \mathrm{d}\end{array}$ \\
\hline RPOMDK & 0.0005 & 0.001 & Refractory particulate organic matter decay rate, $1 / \mathrm{d}$ \\
\hline POMS & 0.25 & 0.50 & Particulate organic matter settling rate, $\mathrm{m} / \mathrm{d}$ \\
\hline OMT2 & 25.0 & 28.0 & Upper temperature parameter for organic matter decay, ${ }^{\circ} \mathrm{C}$ \\
\hline PO4R & 0.00208 & 0.0002 & $\begin{array}{l}\text { Release rate of phosphorus from sediment under anoxic } \\
\text { conditions, as a fraction of the zero-order SOD rate }\end{array}$ \\
\hline NH4R & 0.002 & 0.005 & $\begin{array}{l}\text { Sediment release rate of ammonium under anoxic } \\
\text { conditions, as a fraction of the zero-order SOD rate }\end{array}$ \\
\hline NH4DK & 0.0508 & 0.12 & Ammonia decay (nitrification) rate, $1 / \mathrm{d}$ \\
\hline NO3DK & 2.60 & 0.15 & Nitrate decay (denitrification) rate, $1 / \mathrm{d}$ \\
\hline NO3S & 0.01 & 0.02 & Denitrification rate, loss to sediments, $\mathrm{m} / \mathrm{d}$ \\
\hline SEDCI & 8.0 & 0.0 & Initial sediment concentration, $\mathrm{g} / \mathrm{m}^{2}$ \\
\hline $\mathrm{C} 1$ & $0.2^{1}$ & $\mathrm{NA}^{2}$ & Reaeration equation coefficient (user defined) \\
\hline C2 & $0.05^{1}$ & $\mathrm{NA}^{2}$ & Reaeration equation coefficient (user defined) \\
\hline C3 & $1.75^{1}$ & $\mathrm{NA}^{2}$ & Reaeration equation coefficient (user defined) \\
\hline
\end{tabular}

${ }^{1}$ Lake reaeration equation number 14 was selected for the river.

${ }^{2}$ Not applicable, estuary reaeration equation number 0 was selected for the wetland 
Table 5. Water-quality model macrophyte parameters where values differ for the wetland waterbody

[Abbreviations: ${ }^{\circ} \mathrm{C}$, degrees Celsius; g, gram; $\mathrm{m}^{2} / \mathrm{g}$, square meter per gram; $\mathrm{g} / \mathrm{m}^{3}$, gram per cubic meter; $1 / \mathrm{d}$, per day; $\mathrm{POM}$, particulate organic matter; $\mathrm{W} / \mathrm{m}^{2}$, Watts per square meter]

\begin{tabular}{|c|c|c|c|c|c|}
\hline \multirow[t]{2}{*}{ Parameter } & \multicolumn{3}{|c|}{ WB1 } & \multirow{2}{*}{ WB2 } & \multirow[t]{2}{*}{ Description } \\
\hline & Pondweed & Coontail & $\begin{array}{c}\text { Common } \\
\text { Waterweed }\end{array}$ & & \\
\hline EXM & 0.005 & 0.005 & 0.005 & 0.008 & Macrophyte light extinction, $\mathrm{m}^{2} / \mathrm{g}$ \\
\hline MACWBCI & $-2.0^{1}$ & $-2.0^{1}$ & $-2.0^{1}$ & 1.0 & $\begin{array}{l}\text { Initial macrophyte concentration for each } \\
\text { macrophyte group,g/m } \mathrm{m}^{3}\end{array}$ \\
\hline MG & 0.28 & 0.37 & 0.31 & 0.38 & Maximum macrophyte growth rate, $1 / \mathrm{d}$ \\
\hline MR & 0.07 & 0.09 & 0.09 & 0.09 & Maximum macrophyte respiration rate, $1 / \mathrm{d}$ \\
\hline $\mathrm{MM}$ & 0.06 & 0.07 & 0.06 & 0.04 & Maximum macrophyte mortality rate, $1 / \mathrm{d}$ \\
\hline MSAT & 6 & 3 & 7 & 5 & $\begin{array}{l}\text { light saturation intensity at maximum } \\
\text { photosynthetic rate, } \mathrm{W} / \mathrm{m}^{2}\end{array}$ \\
\hline MPOM & 0.7 & 0.7 & 0.7 & 0.9 & $\begin{array}{l}\text { Fraction of macrophyte biomass that is converted } \\
\text { to particulate organic matter (POM) when } \\
\text { macrophytes die, dimensionless }\end{array}$ \\
\hline LRPMAC & 0.2 & 0.2 & 0.2 & 0.7 & $\begin{array}{l}\text { Fraction of POM which originates as dead } \\
\text { macrophytes becoming labile POM, dimensionless }\end{array}$ \\
\hline PSED & 0.8 & 0.0 & 0.8 & 0.0 & $\begin{array}{l}\text { Fraction of phosphorus uptake by macrophytes } \\
\text { obtained from sediments, dimensionless }\end{array}$ \\
\hline NSED & 0.8 & 0.0 & 0.8 & 0.0 & $\begin{array}{l}\text { Fraction of nitrogen uptake by macrophytes } \\
\text { obtained from sediments, dimensionless }\end{array}$ \\
\hline MEMP & 40 & 40 & 40 & 7 & $\begin{array}{l}\text { Threshold macrophyte concentration for which } \\
\text { growth is moved to the above layer, } \mathrm{g} / \mathrm{m}^{3}\end{array}$ \\
\hline MMAX & 108.0 & 108.0 & 108.0 & 7.0 & Maximum macrophyte concentration, $\mathrm{g} / \mathrm{m}^{3}$ \\
\hline CDDRAG & 0.0 & 0.0 & 0.0 & 0.90 & Macrophyte drag coefficient, dimensionless \\
\hline ANORM & 0.0 & 0.0 & 0.0 & 0.2 & $\begin{array}{l}\text { Fraction of macrophyte surface area normal to } \\
\text { direction of flow, dimensionless }\end{array}$ \\
\hline MT1 & 9.0 & 14.0 & 14.0 & 11.0 & Lower temperature for macrophyte growth, ${ }^{\circ} \mathrm{C}$ \\
\hline MT2 & 15.0 & 24.0 & 24.0 & 20.0 & $\begin{array}{l}\text { Lower temperature for maximum macrophyte } \\
\text { growth, }{ }^{\circ} \mathrm{C}\end{array}$ \\
\hline MT3 & 19.0 & 27.0 & 27.0 & 27.0 & $\begin{array}{l}\text { Upper temperature for maximum macrophyte } \\
\text { growth, }{ }^{\circ} \mathrm{C}\end{array}$ \\
\hline MT4 & 26.0 & 35.0 & 35.0 & 35.0 & Upper temperature for macrophyte growth, ${ }^{\circ} \mathrm{C}$ \\
\hline MK1 & 0.05 & 0.05 & 0.05 & 0.10 & $\begin{array}{l}\text { Fraction of macrophyte growth rate at MT1, } \\
\text { dimensionless }\end{array}$ \\
\hline $\mathrm{MC}$ & 0.50 & 0.52 & 0.50 & 0.52 & $\begin{array}{l}\text { Stoichiometric equivalent between macrophyte } \\
\text { biomass and carbon, dimensionless }\end{array}$ \\
\hline
\end{tabular}

${ }^{1}$ A negative value for this parameter means initial macrophyte populations with a nonuniform longitudinal and vertical पdistribution are given in a separate input file. 
Model Boundary Conditions and Evaporation for the Wetland

Model boundary conditions from previous studies for historical conditions (Sullivan and others, 2013a) were used for the river reach. Headwater boundary conditions, and all tributary inflows and diversions were unchanged. The water quality of the distributed tributary was not changed, but the quantity was modified to account for wetland operations and evaporation.

The wetland was considered active from May 1 through October 31 for each of the four modeled years (2006-09), during which time $5.66 \mathrm{~m}^{3} / \mathrm{s}\left(200 \mathrm{ft}^{3} / \mathrm{s}\right)$ was diverted to the wetland. The addition of $2.73 \times 10^{6} \mathrm{~m}^{2}(675$ acres $)$ of surface area in the model domain led to additional evaporation losses associated with seasonal operation of the wetland. The cumulative annual evaporation for the wetland branch was similar for each model year at about 2.5 million $\mathrm{m}^{3} / \mathrm{yr}(2,027 \mathrm{acre}-\mathrm{ft} / \mathrm{yr})$. Stannard and others (2013) found a 3-year average wetland rate of $0.938 \mathrm{~m} / \mathrm{yr}(3.01 \mathrm{ft} / \mathrm{yr})$, which is similar to the wetland branch rate of $0.92 \mathrm{~m} / \mathrm{yr}(3.00 \mathrm{ft} / \mathrm{yr})$ from the CE-QUAL-W2 model.

Evaporation losses through the wetland and initial filling and end-of-season draining created deviations from the original simulated river water surface elevation. To eliminate those deviations for a more representative comparison of "with" and "without" wetland condition, the original distributed tributary was modified to ensure that the water surface elevation with and without the wetland were similar. Flow of $0.24 \mathrm{~m}^{3} / \mathrm{s}(8.56$ $\left.\mathrm{ft}^{3} / \mathrm{s}\right), 0.15 \mathrm{~m}^{3} / \mathrm{s}\left(5.14 \mathrm{ft}^{3} / \mathrm{s}\right)$, and $-0.15 \mathrm{~m}^{3} / \mathrm{s}(-5.14$ $\mathrm{ft}^{3} / \mathrm{s}$ ) were added to the distributed tributary from Julian Day 121 to 200, 201 to 289, and 290 to 305 , respectively (2008 was adjusted for leap year).

\section{Model Performance}

No data were directly applicable to compare model performance with field observations. Nonetheless, model output was compared with previous pilot scale assessments to determine whether BOD decreases through the wetland were consistent with other approaches.

Previously, a free-water surface wetland reaction rate model (Crites and Tchobanoglous, 1998; Kadlec and Wallace, 2009) was developed and applied to assess potential large-scale wetlands at locations along the Link-Keno reach (Deas and Vaughn, 2006). This analysis used field data to develop removal efficiencies for a wetland of approximately $5.63 \times 10^{6} \mathrm{~m}^{2}$ (1,390 acres), a flowthrough rate of $5.3 \mathrm{~m}^{3} / \mathrm{s}\left(187 \mathrm{ft}^{3} / \mathrm{s}\right)$, and a 4-day residence time at locations along the Link-Keno reach (the size and flow rate are similar to the wetland simulated in this scenario). Locations just downstream of Link River had the highest ultimate carbonaceous BOD removal efficiencies, ranging from 73 to 82 percent. Near Miller Island and downstream to the Klamath Straits Drain, calculated removal efficiencies were 54 percent. Removal rates for the CE-QUAL-W2 wetland near Miller Island in this scenario ranged from 10 to greater than 30 percent for a 5-day residence time. Removal efficiencies in both the reaction rate and CE-QUAL-W2 models followed similar trends with the lowest removal efficiencies early in the season.

\section{Model Sensitivity}

A sensitivity analysis was completed by Sullivan and others (2011) for the Link-Keno model to examine the response of changing selected model parameters to model results. The sensitivity analysis addressed 19 parameters and found that those associated with primary production had notable implications for simulated dissolved oxygen, algae, and nutrient concentrations. For this scenario, selected model parameters were adjusted during model implementation of the wetland branch to determine the sensitivity of the model results in the wetland to those values.

Wind sheltering had a direct effect on hydrodynamics, and thus water-quality conditions. Due to the orientation (approximately north-south) and long fetch, the wide and shallow nature of the wetland, and inherent low velocities, 
notable variability in the wetland flow field velocity direction (upstream and downstream) and magnitude occurred when there was no wind sheltering. With 100 percent wind sheltering, this variability was absent. Complete wind sheltering was considered, but ultimately 81 percent wind sheltering was applied to the wetland based on Poindexter and Variano (2013). At this level of wind sheltering, wind affected the flow rate by up to approximately \pm 25 percent through the course of the May-October season.

Model results were sensitive to several parameters associated with macrophytes, particularly those that directly dictate macrophyte initial and maximum concentration (MACWBCI and MMAX), as well as the threshold macrophyte concentration for which growth is moved to the above layer (MEMP). The spatial and temporal macrophyte concentration and distribution in the wetland had a direct effect on a wide range of processes, particularly in the low velocity, shallow wetland environment. Hydrodynamic parameters related to the macrophyte concentration (for example, CDDRAG and ANORM) affected the hydrodynamics and residence time. Testing also identified that increasing the layer resolution on the mainstem (that is, decreasing modeling layer thickness from $0.6 \mathrm{~m}[2 \mathrm{ft}]$ to $0.3 \mathrm{~m}[1 \mathrm{ft}]$, while maintaining overall depth) impacted macrophyte densities. Specifically, macrophyte densities were decreased in the refined grid. Although most parameters were largely unaffected, dissolved oxygen concentrations decreased with decreased macrophyte densities.

Although many parameters were varied during the course of model construction, results were insensitive to many of those parameters in the shallow, low velocity wetland environment. Bed slope and roughness had little effect because of the low velocities. Results were only moderately sensitive to changes in the decay rates of dissolved organic matter. Similarly, the nitrification rate, while higher in the wetland, was still only modestly important to model results. Results were moderately sensitive to changes in the settling rates for particulate material because the shallow depths resulted in much material settling out relatively quickly.

\section{Model Application and Wetland Results}

The modified CE-QUAL-W2 model was applied to a single wetland configuration located near Miller Island. Multiple chemical, biological, and physical water-quality constituents (including derived constituents) were simulated to evaluate the effect of the wetland on the fate of organic matter, as well as nutrients, algae, and other water-quality constituents. These are presented below, and results are presented longitudinally at several locations within the wetland from the headwater (segment 111) to the last full width segment (segment 124) to examine potential wetland effects. Herein, "background" concentrations refer to the concentrations of these constituents produced naturally by these biological systems. 


\section{Organic Carbon}

Organic carbon $(\mathrm{OC})$ response through the wetland differed depending on form: particulate (POC) or dissolved (DOC). The particulate form was progressively decreased through the wetland (fig. 10), with decreases ranging from 59 to greater than 80 percent (table 6). While the inflow POC concentrations changed through the season, the outflow concentration tended to remain roughly constant at approximately 1.0 $\mathrm{mg} / \mathrm{L}$. This stable condition characterized the potential background concentration of the wetland (that is, that constituent concentration that the wetland produced). DOC passed through the wetland with little change, occasionally showing a slight increase or decrease with an average increase in the four simulation years of approximately 1 percent (table 7).

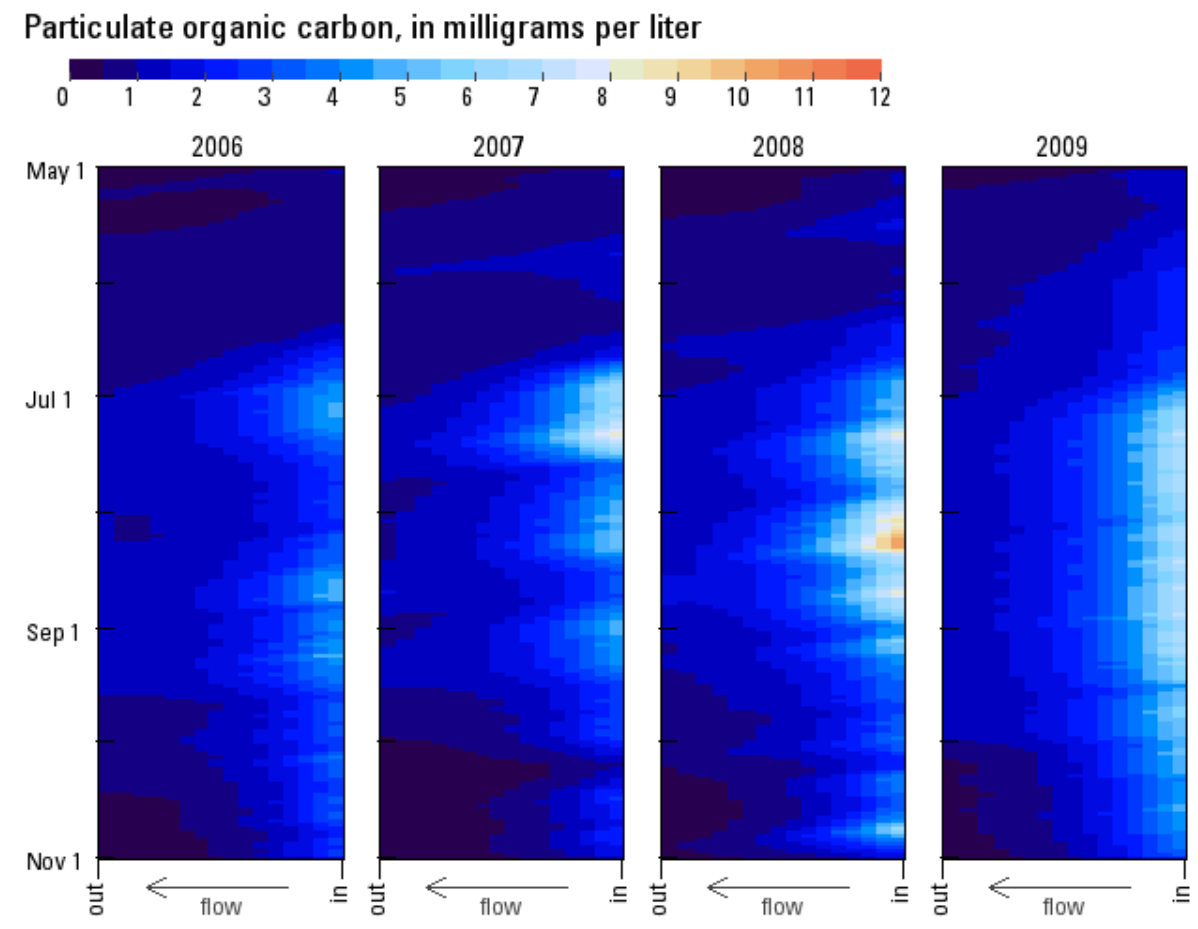

Figure 10. Graphs showing particulate organic carbon concentrations through the wetland for the operational period (May 1-October 31) for 2006-09. 
Table 6. Monthly particulate organic carbon concentrations for the simulated wetland in the LinkKeno reach of the Klamath River.

[Results for the head and downstream end of the wetland, including percent reduction based on segments 28 and 124, are shown for 2006-09. Concentrations given in milligrams per liter. Abbreviations: Seg., model segment]

\begin{tabular}{|c|c|c|c|c|c|c|c|c|}
\hline \multirow{3}{*}{ Month } & \multicolumn{4}{|c|}{2006} & \multicolumn{4}{|c|}{2007} \\
\hline & \multirow{2}{*}{$\begin{array}{c}\text { River } \\
\text { Seg. } 28^{1}\end{array}$} & \multicolumn{2}{|c|}{ Wetland } & \multirow{2}{*}{$\begin{array}{c}\text { Percent } \\
\text { decrease }\end{array}$} & \multirow{2}{*}{$\begin{array}{c}\text { River } \\
\text { Seg. } 28^{1}\end{array}$} & \multicolumn{2}{|c|}{ Wetland } & \multirow{2}{*}{$\begin{array}{c}\text { Percent } \\
\text { decrease }\end{array}$} \\
\hline & & Seg. $111^{2}$ & Seg. $124^{2}$ & & & Seg. $111^{2}$ & Seg. $124^{2}$ & \\
\hline June & 2.10 & 1.98 & 0.86 & $59 \%$ & 2.59 & 2.41 & 0.82 & $68 \%$ \\
\hline July & 3.58 & 3.37 & 1.14 & $68 \%$ & 5.88 & 5.47 & 1.20 & $80 \%$ \\
\hline August & 3.93 & 3.65 & 1.09 & $72 \%$ & 4.41 & 4.11 & 1.12 & $75 \%$ \\
\hline September & 3.85 & 3.54 & 1.03 & $73 \%$ & 3.75 & 3.31 & 0.92 & $75 \%$ \\
\hline \multirow[t]{2}{*}{ October } & 3.19 & 2.81 & 0.51 & $84 \%$ & 2.15 & 1.90 & 0.26 & $88 \%$ \\
\hline & \multicolumn{4}{|c|}{2008} & \multicolumn{4}{|c|}{2009} \\
\hline \multirow[t]{2}{*}{ Month } & River & \multicolumn{2}{|c|}{ Wetland } & $\begin{array}{l}\text { Percent } \\
\text { decrease }\end{array}$ & River & \multicolumn{2}{|c|}{ Wetland } & $\begin{array}{l}\text { Percent } \\
\text { decrease }\end{array}$ \\
\hline & Seg. $28^{1}$ & Seg. $111^{2}$ & Seg. $124^{2}$ & & Seg. $28^{1}$ & Seg. $111^{2}$ & Seg.124² & \\
\hline June & 2.73 & 2.54 & 0.95 & $65 \%$ & 2.95 & 2.76 & 0.99 & $67 \%$ \\
\hline July & 6.65 & 6.17 & 1.21 & $82 \%$ & 7.09 & 6.40 & 1.34 & $81 \%$ \\
\hline August & 8.12 & 7.27 & 1.49 & $82 \%$ & 7.43 & 6.56 & 1.39 & $81 \%$ \\
\hline September & 4.20 & 3.76 & 0.97 & $77 \%$ & 6.46 & 5.72 & 1.30 & $80 \%$ \\
\hline October & 3.84 & 3.42 & 0.51 & $87 \%$ & 4.78 & 4.30 & 0.57 & $88 \%$ \\
\hline
\end{tabular}

\footnotetext{
${ }^{1}$ Withdrawn from layer 15, assumed intake of pump
}

${ }^{2}$ Volume averaged concentration of segment 
Table 7. Monthly dissolved organic carbon concentrations for the simulated wetland in the LinkKeno reach of the Klamath River.

[Results for the head and downstream end of the wetland, including percent reduction based on segments 28 and 124, are shown for 2006-09. Concentrations given in milligrams per liter. Abbreviations: Seg., model segment]

\begin{tabular}{|c|c|c|c|c|c|c|c|c|}
\hline & \multicolumn{4}{|c|}{2006} & \multicolumn{4}{|c|}{2007} \\
\hline \multirow[t]{2}{*}{ Month } & River & \multicolumn{2}{|c|}{ Wetland } & \multirow[t]{2}{*}{$\begin{array}{c}\text { Percent } \\
\text { decrease }\end{array}$} & \multirow{2}{*}{$\begin{array}{c}\text { River } \\
\text { Seg. } 28^{1}\end{array}$} & \multicolumn{2}{|c|}{ Wetland } & \multirow[t]{2}{*}{$\begin{array}{c}\text { Percent } \\
\text { decrease }\end{array}$} \\
\hline & Seg. $28^{1}$ & Seg. $111^{2}$ & Seg. $124^{2}$ & & & Seg. $111^{2}$ & Seg. $124^{2}$ & \\
\hline June & 7.03 & 7.04 & 7.20 & $-2 \%$ & 7.09 & 7.11 & 7.21 & $-2 \%$ \\
\hline July & 10.23 & 10.29 & 9.98 & $2 \%$ & 10.10 & 10.22 & 9.59 & $5 \%$ \\
\hline August & 11.32 & 11.43 & 11.47 & $-1 \%$ & 12.15 & 12.38 & 12.35 & $-2 \%$ \\
\hline September & 11.23 & 11.31 & 11.65 & $-4 \%$ & 12.56 & 12.59 & 12.82 & $-2 \%$ \\
\hline \multirow[t]{2}{*}{ October } & 10.85 & 10.90 & 11.06 & $-2 \%$ & 10.61 & 10.61 & 10.76 & $-1 \%$ \\
\hline & \multicolumn{4}{|c|}{2008} & \multicolumn{4}{|c|}{2009} \\
\hline \multirow[t]{2}{*}{ Month } & River & \multicolumn{2}{|c|}{ Wetland } & $\begin{array}{c}\text { Percent } \\
\text { decrease }\end{array}$ & River & \multicolumn{2}{|c|}{ Wetland } & $\begin{array}{c}\text { Percent } \\
\text { decrease }\end{array}$ \\
\hline & Seg. $28^{1}$ & Seg. $111^{2}$ & Seg. $124^{2}$ & & Seg. $28^{1}$ & Seg. $111^{2}$ & Seg. $124^{2}$ & \\
\hline June & 6.79 & 6.84 & 7.22 & $-6 \%$ & 6.02 & 6.05 & 6.14 & $-2 \%$ \\
\hline July & 8.61 & 8.68 & 8.40 & $2 \%$ & 7.80 & 7.79 & 7.72 & $1 \%$ \\
\hline August & 10.26 & 10.41 & 10.28 & $0 \%$ & 8.06 & 8.06 & 8.15 & $-1 \%$ \\
\hline September & 10.50 & 10.67 & 10.70 & $-2 \%$ & 8.01 & 8.00 & 8.11 & $-1 \%$ \\
\hline October & 9.91 & 9.91 & 10.17 & $-3 \%$ & 7.87 & 7.87 & 7.85 & $0 \%$ \\
\hline
\end{tabular}

${ }^{1}$ Withdrawn from layer 15, assumed intake of pump

${ }^{2}$ Volume averaged concentration of segment

\section{Nutrients}

Decreases in concentrations of total nitrogen (TN) were modest early in the year, with notable decreases in July-October (fig. 11). Overall decreases ranged from 10 to 45 percent (table 8). Ammonia concentrations decreased from the range of 0.4 to $0.6 \mathrm{mg} / \mathrm{L}$ to 0 in the wetland from July through late in the operations season (fig. 12), but nitrate concentrations changed little through the wetland (fig. 13).

Total phosphorus (TP) showed decreased concentrations through the wetland that ranged from 2 to 48 percent (fig. 14; table 9).

Considering that October reductions ranged from 2 to 18 percent (average of 8.5 percent), summer periods showed larger reductions.

Orthophosphorus concentrations decreased notably early in the season as macrophytes were actively growing. Thereafter, concentrations were decreased through the wetland by about 20-30 percent throughout much of the July-August period. September and October saw ever decreasing reductions (fig. 15). 
Total nitrogen, in milligrams per liter

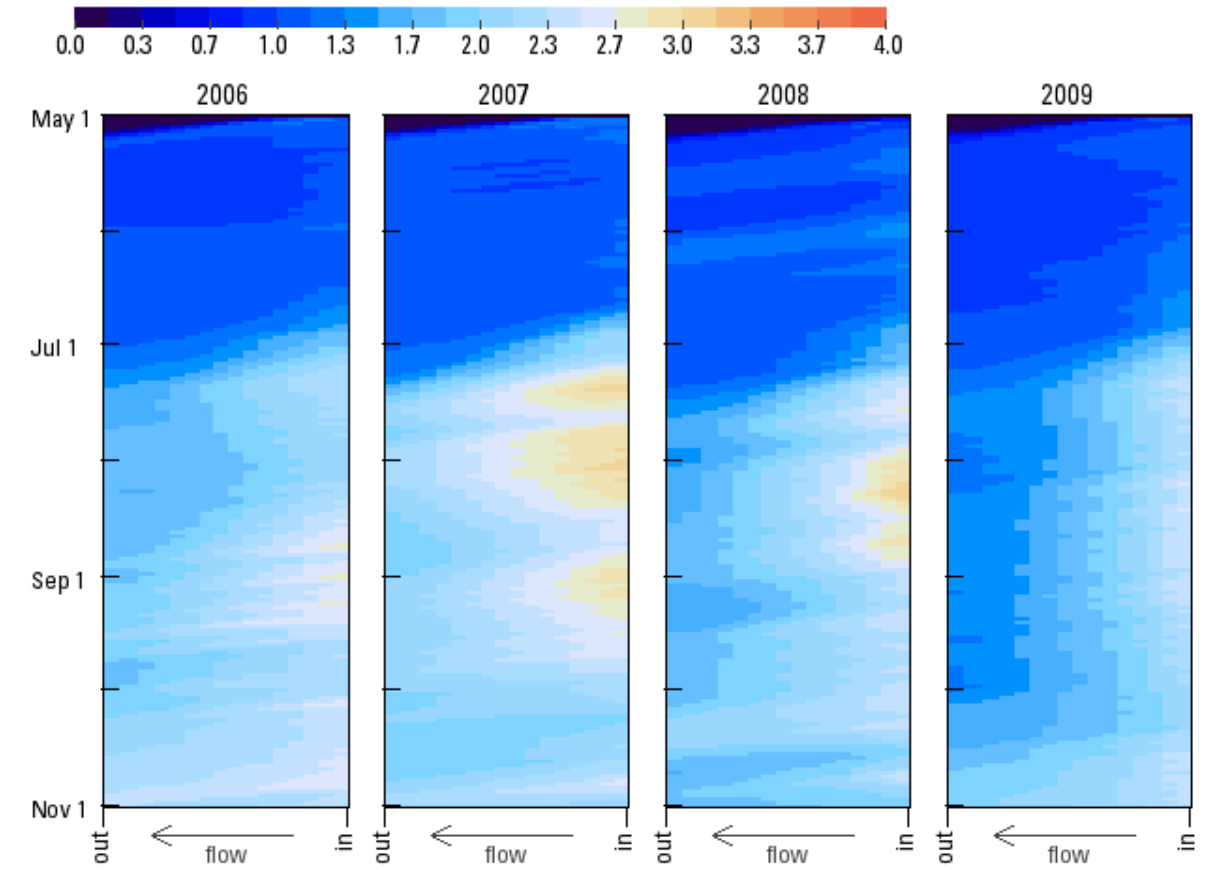

Figure 11. Graphs showing total nitrogen concentrations through the wetland for the operational period (May 1-October 31) for 2006-09.

Ammonia, in milligrams per liter

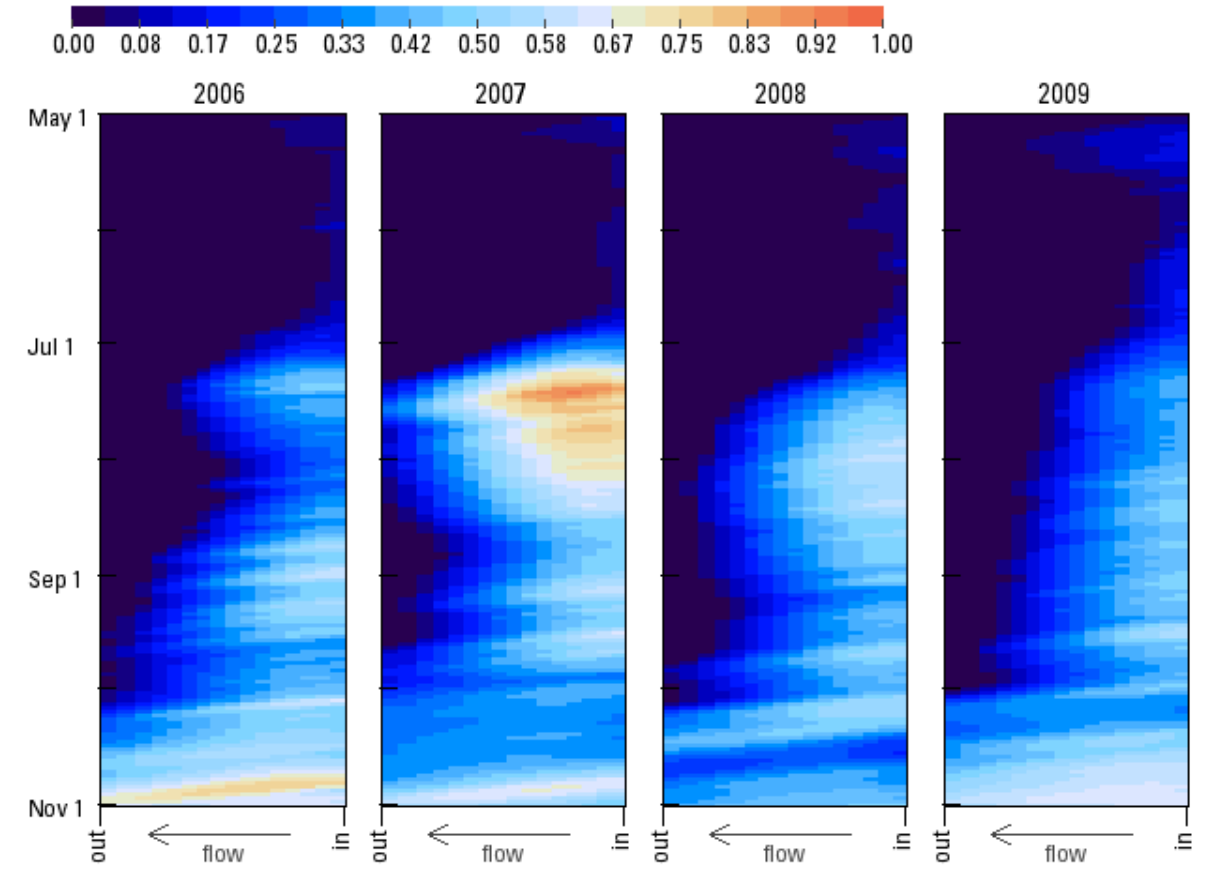

Figure 12. Graphs showing ammonia concentrations through the wetland for the operational period (May 1-October 31) for 2006-09. 
Nitrate+Nitrite, in milligrams per liter

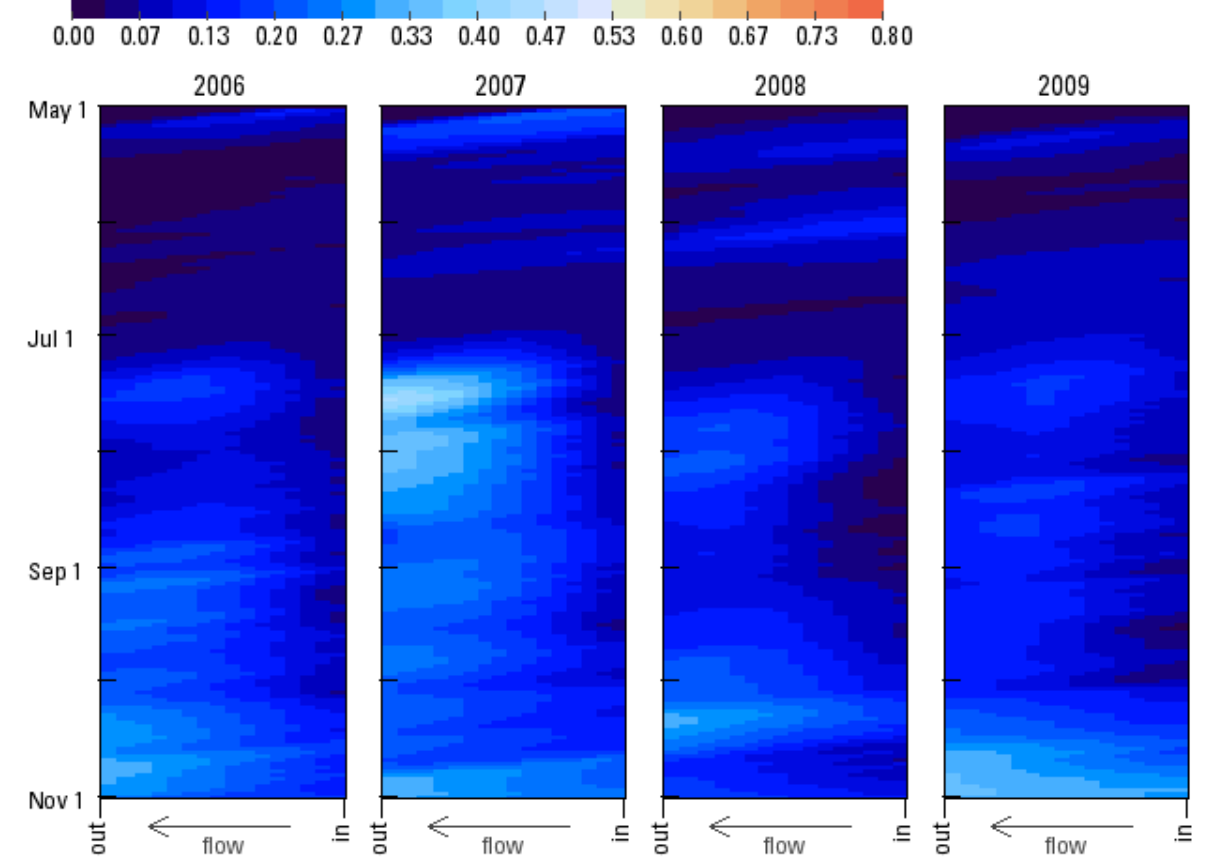

Figure 13. Graphs showing nitrate concentrations through the wetland for the operational period (May 1-October 31) for 2006-09. 
Total phosphorus, in milligrams per liter

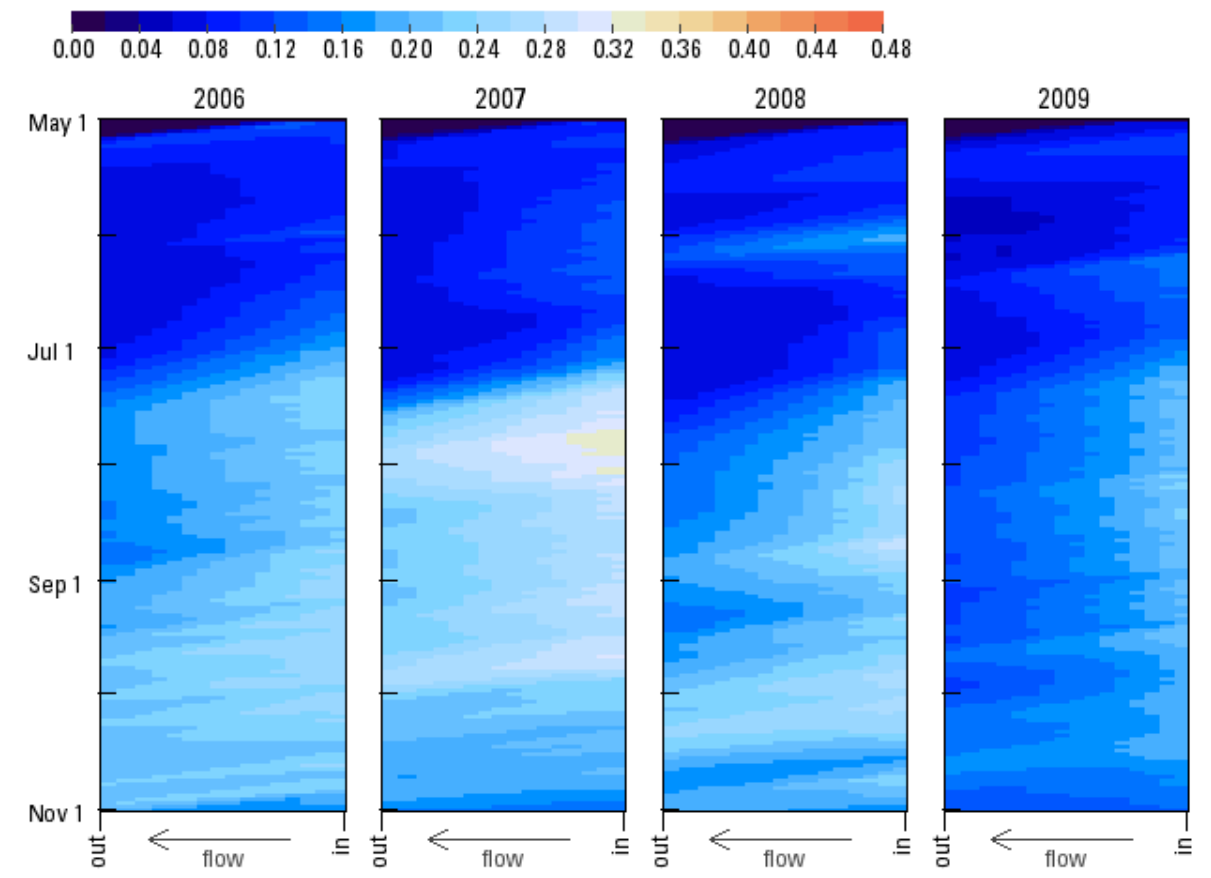

Figure 14. Graphs showing total phosphorus concentrations through the wetland for the operational period (May 1-October 31) for 2006-09.

Orthophosphorus, in milligrams per liter

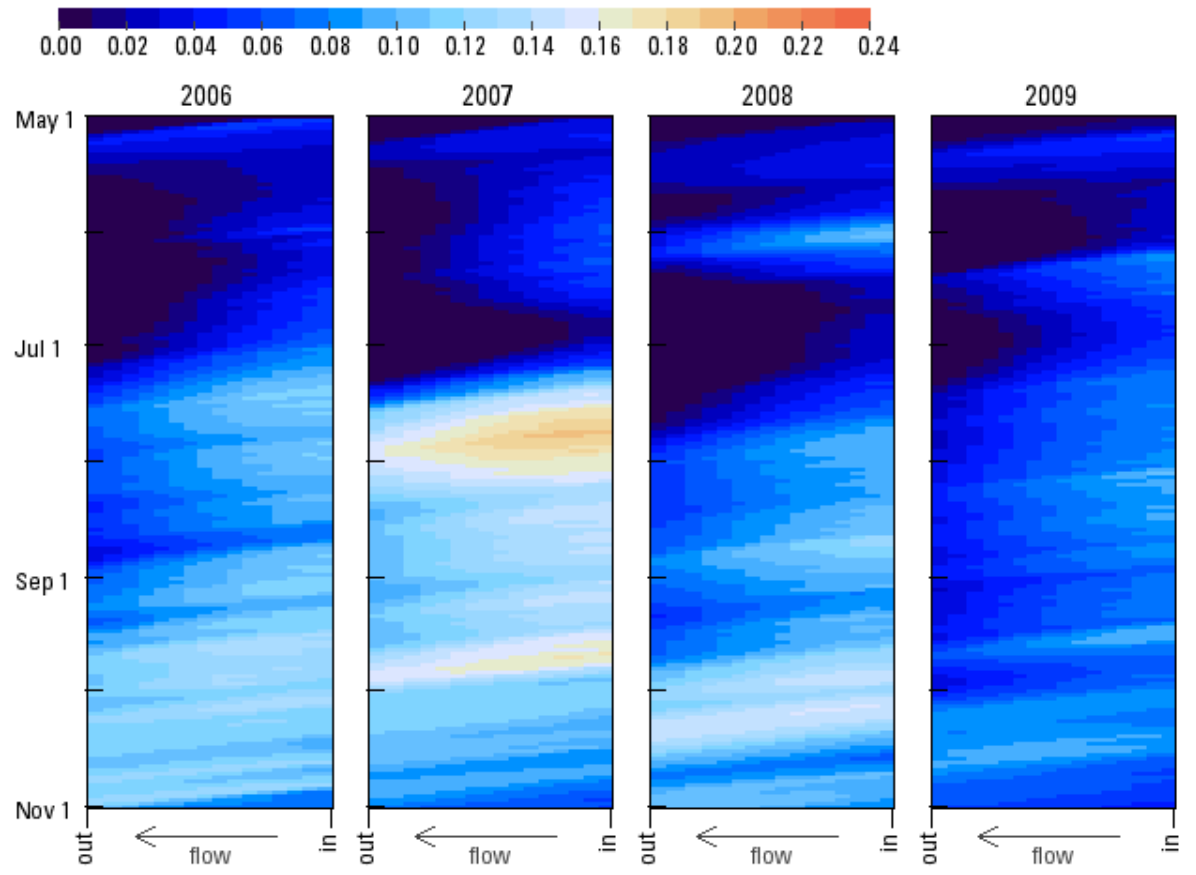

Figure 15. Graphs showing orthophosphorus concentrations through the wetland for the operational period (May 1-October 31) for 2006-09. 
Table 8. Monthly total nitrogen concentrations for the simulated wetland in the Link-Keno reach of the Klamath River.

[Results for the head and downstream end of the wetland, including percent reduction based on segments 28 and 124, are shown for 2006-09. Concentrations given in milligrams per liter.

Abbreviations: Seg., model segment]

\begin{tabular}{|c|c|c|c|c|c|c|c|c|}
\hline & \multicolumn{4}{|c|}{2006} & \multicolumn{4}{|c|}{2007} \\
\hline \multirow[t]{2}{*}{ Month } & River & \multicolumn{2}{|c|}{ Wetland } & \multirow[t]{2}{*}{$\begin{array}{c}\text { Percent } \\
\text { decrease }\end{array}$} & River & \multicolumn{2}{|c|}{ Wetland } & $\begin{array}{c}\text { Percent } \\
\text { decrease }\end{array}$ \\
\hline & Seg. $28^{1}$ & Seg. $111^{2}$ & Seg. $124^{2}$ & & Seg. $28^{1}$ & Seg. $111^{2}$ & Seg. $124^{2}$ & \\
\hline June & 1.30 & 1.28 & 1.07 & $18 \%$ & 1.41 & 1.37 & 1.08 & $23 \%$ \\
\hline July & 2.19 & 2.15 & 1.54 & $29 \%$ & 2.76 & 2.75 & 1.88 & $32 \%$ \\
\hline August & 2.45 & 2.41 & 1.75 & $29 \%$ & 2.77 & 2.77 & 2.11 & $24 \%$ \\
\hline September & 2.47 & 2.43 & 1.94 & $21 \%$ & 2.68 & 2.62 & 2.12 & $21 \%$ \\
\hline \multirow[t]{2}{*}{ October } & 2.49 & 2.46 & 2.16 & $13 \%$ & 2.23 & 2.19 & 2.01 & $10 \%$ \\
\hline & \multicolumn{4}{|c|}{2008} & \multicolumn{4}{|c|}{2009} \\
\hline \multirow[t]{2}{*}{ Month } & River & \multicolumn{2}{|c|}{ Wetland } & $\begin{array}{c}\text { Percent } \\
\text { decrease }\end{array}$ & River & \multicolumn{2}{|c|}{ Wetland } & $\begin{array}{c}\text { Percent } \\
\text { decrease }\end{array}$ \\
\hline & Seg. $28^{1}$ & Seg. $111^{2}$ & Seg. $124^{2}$ & & Seg. $28^{1}$ & Seg. $111^{2}$ & Seg. $124^{2}$ & \\
\hline June & 1.37 & 1.33 & 1.11 & $19 \%$ & 1.40 & 1.36 & 0.98 & $30 \%$ \\
\hline July & 2.41 & 2.36 & 1.37 & $43 \%$ & 2.34 & 2.27 & 1.29 & $45 \%$ \\
\hline August & 2.86 & 2.81 & 1.74 & $39 \%$ & 2.47 & 2.41 & 1.37 & $44 \%$ \\
\hline September & 2.35 & 2.35 & 1.71 & $27 \%$ & 2.35 & 2.28 & 1.40 & $41 \%$ \\
\hline October & 2.27 & 2.22 & 1.89 & $17 \%$ & 2.31 & 2.25 & 1.73 & $25 \%$ \\
\hline
\end{tabular}

${ }^{1}$ Withdrawn from layer 15 , assumed intake of pump

${ }^{2}$ Volume averaged concentration of segment 
Table 9. Monthly total phosphorus concentrations (milligrams per liter) for the simulated wetland in the Link-Keno reach of the Klamath River.

[Results for the head and downstream end of the wetland, including percent reduction based on segments 28 and 124, are shown for 2006-09. Concentrations given in milligrams per liter.

Abbreviations: Seg., model segment]

\begin{tabular}{|c|c|c|c|c|c|c|c|c|}
\hline & \multicolumn{4}{|c|}{2006} & \multicolumn{4}{|c|}{2007} \\
\hline \multirow[t]{2}{*}{ Month } & River & \multicolumn{2}{|c|}{ Wetland } & \multirow[t]{2}{*}{$\begin{array}{l}\text { Percent } \\
\text { decrease }\end{array}$} & \multirow{2}{*}{$\frac{\text { River }}{\text { Seg. } 28^{1}}$} & \multicolumn{2}{|c|}{ Wetland } & $\begin{array}{l}\text { Percent } \\
\text { decrease }\end{array}$ \\
\hline & Seg. $28^{1}$ & Seg. $111^{2}$ & Seg. $124^{2}$ & & & Seg. $111^{2}$ & Seg. $124^{2}$ & \\
\hline June & 0.13 & 0.13 & 0.07 & $45 \%$ & 0.13 & 0.13 & 0.07 & $43 \%$ \\
\hline July & 0.23 & 0.22 & 0.15 & $32 \%$ & 0.28 & 0.27 & 0.18 & $36 \%$ \\
\hline August & 0.23 & 0.23 & 0.17 & $27 \%$ & 0.29 & 0.29 & 0.24 & $18 \%$ \\
\hline September & 0.25 & 0.25 & 0.21 & $19 \%$ & 0.29 & 0.28 & 0.24 & $16 \%$ \\
\hline \multirow[t]{2}{*}{ October } & 0.23 & 0.23 & 0.22 & $6 \%$ & 0.20 & 0.20 & 0.20 & $2 \%$ \\
\hline & \multicolumn{4}{|c|}{2008} & \multicolumn{4}{|c|}{2009} \\
\hline \multirow[t]{2}{*}{ Month } & River & \multicolumn{2}{|c|}{ Wetland } & $\begin{array}{l}\text { Percent } \\
\text { decrease }\end{array}$ & River & \multicolumn{2}{|c|}{ Wetland } & $\begin{array}{l}\text { Percent } \\
\text { decrease }\end{array}$ \\
\hline & Seg. $28^{1}$ & Seg. $111^{2}$ & Seg. $124^{2}$ & & Seg. $28^{1}$ & Seg. $111^{2}$ & Seg. $124^{2}$ & \\
\hline June & 0.12 & 0.12 & 0.09 & $31 \%$ & 0.14 & 0.13 & 0.07 & $48 \%$ \\
\hline July & 0.20 & 0.20 & 0.10 & $48 \%$ & 0.21 & 0.20 & 0.11 & $48 \%$ \\
\hline August & 0.26 & 0.26 & 0.17 & $34 \%$ & 0.22 & 0.21 & 0.13 & $40 \%$ \\
\hline September & 0.24 & 0.24 & 0.18 & $24 \%$ & 0.20 & 0.20 & 0.13 & $36 \%$ \\
\hline October & 0.22 & 0.22 & 0.21 & $8 \%$ & 0.18 & 0.18 & 0.15 & $18 \%$ \\
\hline
\end{tabular}

${ }^{1}$ Withdrawn from layer 15 , assumed intake of pump

${ }^{2}$ Volume averaged concentration of segment 


\section{Algae and Chlorophyll a}

Of the three species of algae represented in the CE-QUAL-W2 model, blue-green algae (BGA) exhibited the highest inflow concentration and settling in the wetland (fig. 16; table 10). Diatoms and "other" algae were present in low numbers during the May-October season and are not discussed further. Chlorophyll $a$ largely mimicked BGA concentrations (fig. 17), but had overall higher background levels leaving the wetland, suggesting that although diatoms and "other" algae did not yield the large bloom-like conditions of BGA, a low level was present at times.

Blue-green algae, in milligrams per liter

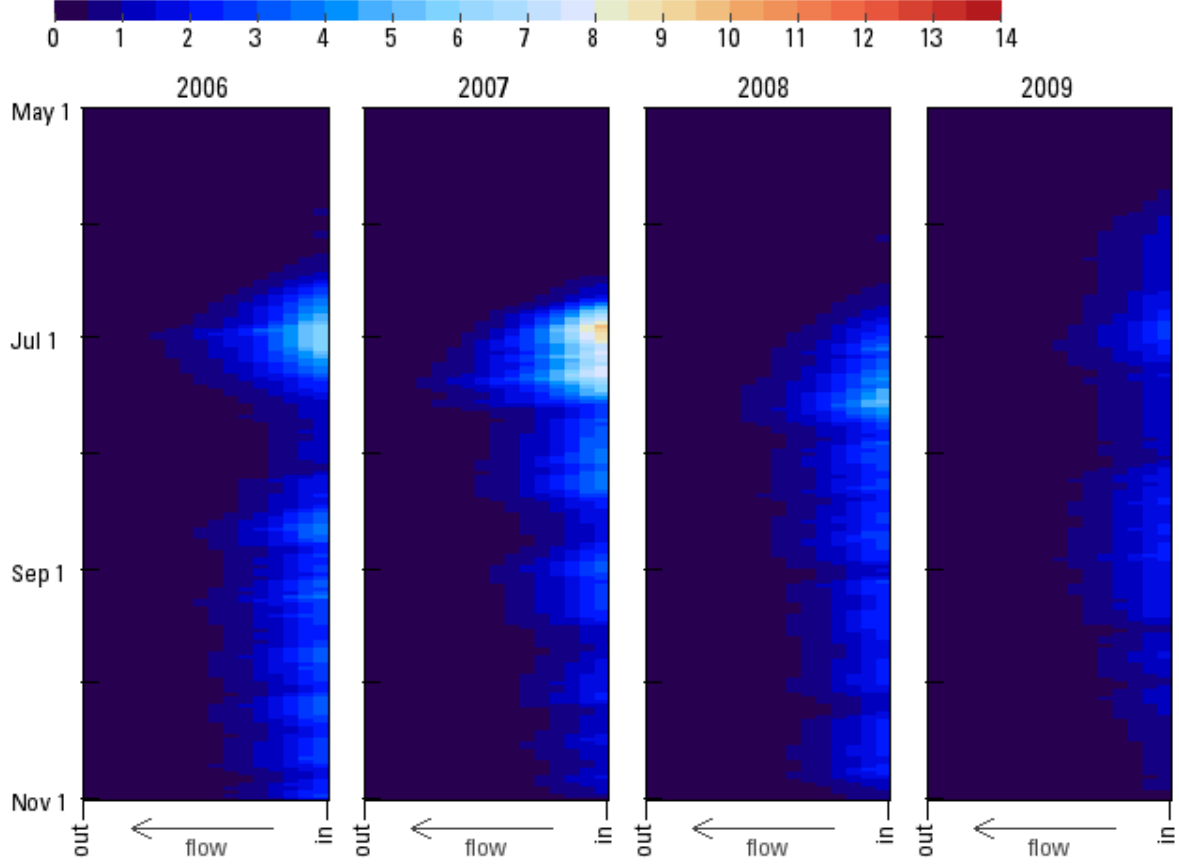

Figure 16. Graphs showing blue-green algae concentrations through the wetland for the operational period (May 1-October 31) for 2006-09. 
Table 10. Monthly blue-green algae concentrations (milligrams per liter) for the simulated wetland in the Link-Keno reach of the Klamath River.

[Results for the head and downstream end of the wetland, including percent reduction based on segments 28 and 124, are shown for 2006-09. Concentrations given in milligrams per liter.

Abbreviations: Seg., model segment]

\begin{tabular}{|c|c|c|c|c|c|c|c|c|}
\hline \multirow{3}{*}{ Month } & \multicolumn{4}{|c|}{2006} & \multicolumn{4}{|c|}{2007} \\
\hline & \multirow{2}{*}{$\begin{array}{c}\text { River } \\
\text { Seg. } \mathbf{2 8}^{1} \\
\end{array}$} & \multicolumn{2}{|c|}{ Wetland } & \multirow[t]{2}{*}{$\begin{array}{c}\text { Percent } \\
\text { decrease }\end{array}$} & \multirow{2}{*}{$\begin{array}{c}\text { River } \\
\text { Seg. } 28^{1} \\
\end{array}$} & \multicolumn{2}{|c|}{ Wetland } & \multirow[t]{2}{*}{$\begin{array}{l}\text { Percent } \\
\text { decrease }\end{array}$} \\
\hline & & Seg. $111^{2}$ & Seg. $124^{2}$ & & & Seg. $111^{2}$ & Seg. $124^{2}$ & \\
\hline June & 2.64 & 2.36 & 0.05 & $98 \%$ & 2.89 & 2.57 & 0.02 & $99 \%$ \\
\hline July & 2.72 & 2.63 & 0.13 & $95 \%$ & 4.98 & 5.19 & 0.22 & $96 \%$ \\
\hline August & 2.27 & 2.28 & 0.07 & $97 \%$ & 2.67 & 2.68 & 0.09 & $97 \%$ \\
\hline September & 3.11 & 2.83 & 0.10 & $97 \%$ & 2.30 & 2.00 & 0.07 & $97 \%$ \\
\hline \multirow[t]{2}{*}{ October } & 2.99 & 2.48 & 0.09 & $97 \%$ & 1.73 & 1.42 & 0.05 & $97 \%$ \\
\hline & \multicolumn{4}{|c|}{2008} & \multicolumn{4}{|c|}{2009} \\
\hline \multirow[t]{2}{*}{ Month } & River & \multicolumn{2}{|c|}{ Wetland } & $\begin{array}{c}\text { Percent } \\
\text { decrease }\end{array}$ & River & \multicolumn{2}{|c|}{ Wetland } & $\begin{array}{c}\text { Percent } \\
\text { decrease }\end{array}$ \\
\hline & Seg. $2^{1}$ & Seg. $111^{2}$ & Seg. $124^{2}$ & & Seg. $28^{1}$ & Seg. $111^{2}$ & Seg. $124^{2}$ & \\
\hline June & 0.97 & 0.87 & 0.01 & $99 \%$ & 1.78 & 1.64 & 0.05 & $97 \%$ \\
\hline July & 3.44 & 3.47 & 0.11 & $97 \%$ & 1.27 & 1.43 & 0.06 & $95 \%$ \\
\hline August & 2.30 & 2.43 & 0.11 & $95 \%$ & 1.83 & 1.82 & 0.07 & $96 \%$ \\
\hline September & 2.29 & 2.14 & 0.07 & $97 \%$ & 1.69 & 1.51 & 0.06 & $96 \%$ \\
\hline October & 2.10 & 1.74 & 0.07 & $97 \%$ & 0.96 & 0.79 & 0.03 & $97 \%$ \\
\hline
\end{tabular}

${ }^{1}$ Withdrawn from layer 15 , assumed intake of pump

${ }^{2}$ Volume averaged concentration of segment 


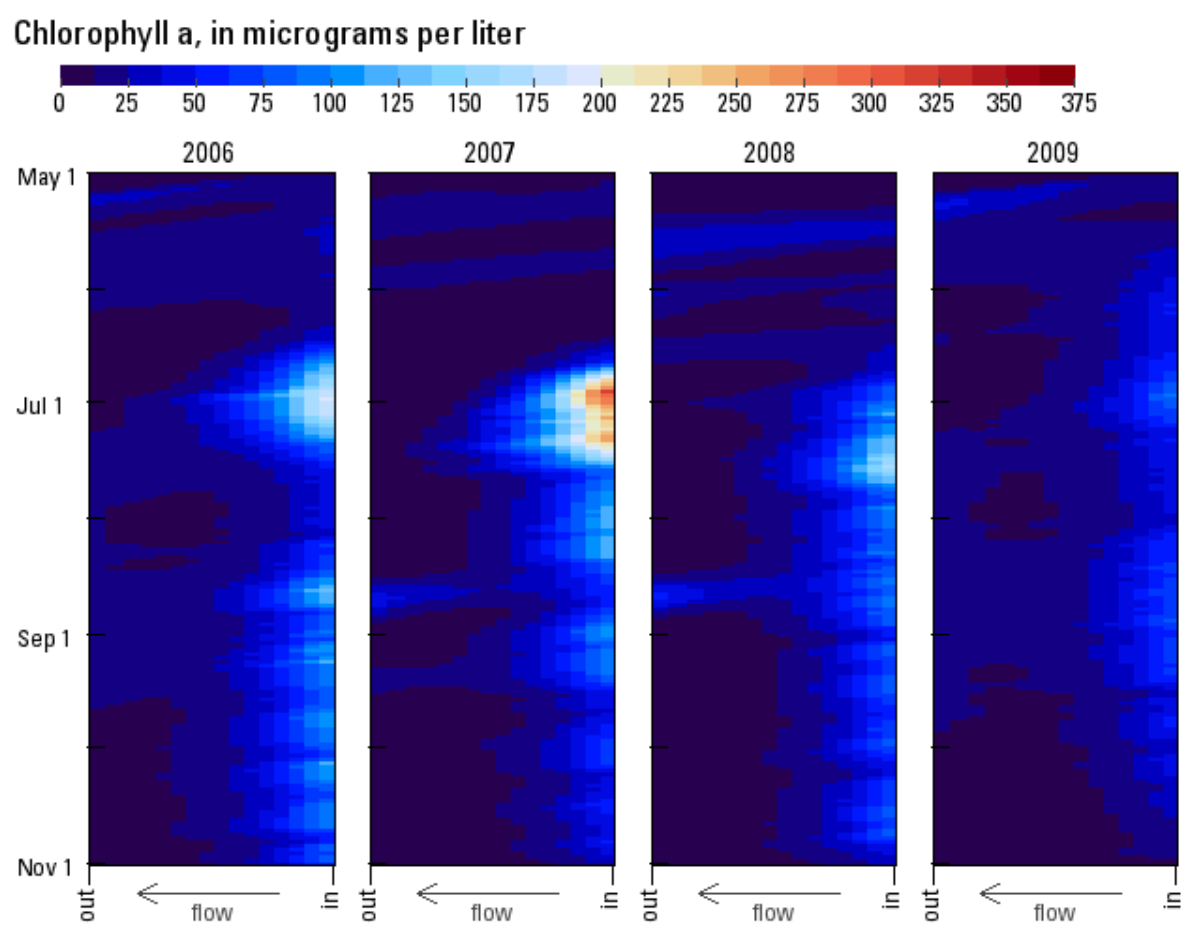

Figure 17. Graphs showing chlorophyll a concentrations through the wetland for the operational period (May 1-October 31) for 2006-09.

\section{Macrophytes}

In the simulated wetland, macrophytes began growing at the beginning of the treatment period (around day 124, early May) and grew at approximately the same rate in layers 6 and 7 . This is largely a function of how macrophytes are modeled in CE-QUAL-W2. Macrophytes began at a standing crop of approximately $3 \mathrm{~g} / \mathrm{m}^{3}$ in layer 7 and $0 \mathrm{~g} / \mathrm{m}^{3}$ in layer 6 . Once the macrophyte concentration in layer 7 reached approximately $5 \mathrm{~g} / \mathrm{m}^{3}$, macrophytes began to grow into layer 6 . Macrophytes continued to grow in both layers until they reached a maximum concentration of $21 \mathrm{~g} / \mathrm{m}^{3}$ for the rest of the treatment period (the maximum macrophyte concentration [MMAX, table 5] was user specified, but the model simulates the rate of growth up to that limit). 


\section{Dissolved Oxygen}

Prior to July 1, inflowing dissolved oxygen concentrations ranged around $9 \mathrm{mg} / \mathrm{L}$ and outflows averaged approximately $11 \mathrm{mg} / \mathrm{L}$. From July 1 through October 31 , dissolved oxygen influent concentrations ranged from 2 to $6 \mathrm{mg} / \mathrm{L}$ (subsaturation), but waters diverted through the wetland had average outflow concentrations ranging from 8 to $9 \mathrm{mg} / \mathrm{L}$ through late in the operational season (fig. 18). Increases in dissolved oxygen concentration through the wetlands were often large because of the low influent concentrations (table 11), and in nearly all cases wetland outflow concentrations were near saturation.

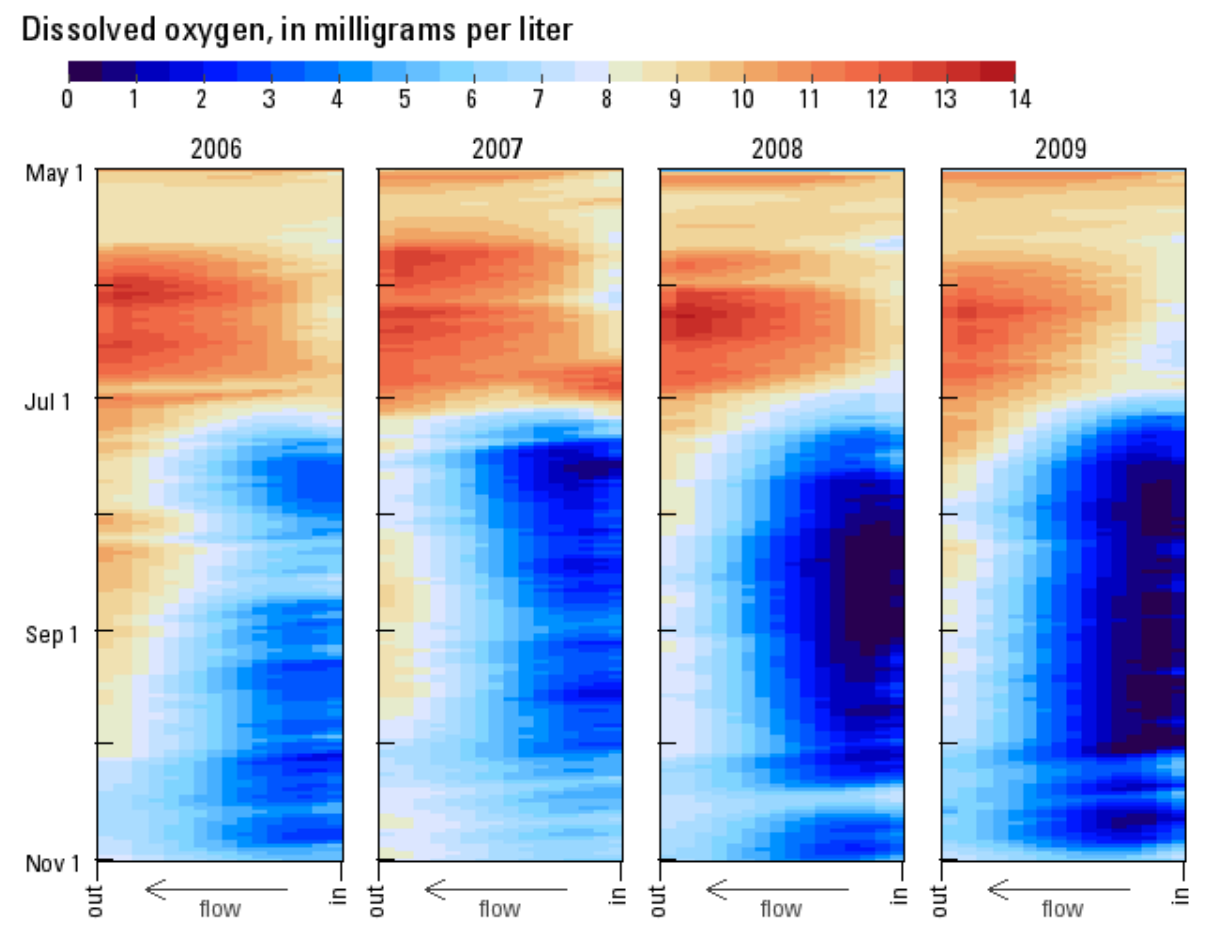

Figure 18. Graphs showing dissolved oxygen concentrations through the wetland for the operational period (May 1-October 31) for 2006-09. 
Table 11. Monthly dissolved oxygen concentrations (milligrams per liter) for the simulated wetland in the Link-Keno reach of the Klamath River.

[Results for the head and downstream end of the wetland, including percent reduction based on segments 28 and 124, are shown for 2006-09. Concentrations given in milligrams per liter.

Abbreviations: Seg., model segment]

\begin{tabular}{|c|c|c|c|c|c|c|c|c|}
\hline \multirow{3}{*}{ Month } & \multicolumn{4}{|c|}{2006} & \multicolumn{4}{|c|}{2007} \\
\hline & \multirow{2}{*}{$\begin{array}{c}\text { River } \\
\text { Seg. } 28^{1} \\
\end{array}$} & \multicolumn{2}{|c|}{ Wetland } & \multirow[t]{2}{*}{$\begin{array}{c}\text { Percent } \\
\text { decrease }\end{array}$} & \multirow{2}{*}{$\begin{array}{c}\text { River } \\
\text { Seg. } \mathbf{2 8}^{1}\end{array}$} & \multicolumn{2}{|c|}{ Wetland } & \multirow[t]{2}{*}{$\begin{array}{c}\text { Percent } \\
\text { decrease }\end{array}$} \\
\hline & & Seg. $111^{2}$ & Seg. $124^{2}$ & & & Seg. $111^{2}$ & Seg. $124^{2}$ & \\
\hline June & 8.65 & \begin{tabular}{|l|}
9.01 \\
\end{tabular} & 11.80 & $-36 \%$ & 8.88 & 9.50 & 11.72 & $-32 \%$ \\
\hline July & 3.35 & 5.20 & 8.96 & $-167 \%$ & 1.38 & 4.20 & 7.62 & $-453 \%$ \\
\hline August & 2.68 & 5.21 & 9.03 & $-237 \%$ & 0.30 & 3.08 & 7.79 & $-2,525 \%$ \\
\hline September & 1.75 & 3.86 & 8.00 & $-357 \%$ & 0.76 & 3.02 & 7.74 & $-919 \%$ \\
\hline \multirow[t]{2}{*}{ October } & 2.87 & 3.62 & 6.82 & $-138 \%$ & 5.02 & 5.44 & 7.35 & $-46 \%$ \\
\hline & \multicolumn{4}{|c|}{2008} & \multicolumn{4}{|c|}{2009} \\
\hline \multirow[t]{2}{*}{ Month } & River & \multicolumn{2}{|c|}{ Wetland } & $\begin{array}{c}\text { Percent } \\
\text { decrease }\end{array}$ & River & \multicolumn{2}{|c|}{ Wetland } & $\begin{array}{c}\text { Percent } \\
\text { decrease }\end{array}$ \\
\hline & Seg. $28^{1}$ & Seg. $111^{2}$ & Seg. $124^{2}$ & & Seg. $2^{1}$ & Seg. $111^{2}$ & Seg. $124^{2}$ & \\
\hline June & 7.88 & 8.44 & 12.09 & $-54 \%$ & 6.88 & 7.79 & 11.52 & $-68 \%$ \\
\hline July & 1.69 & 3.82 & 8.11 & $-380 \%$ & 0.95 & 2.28 & 8.40 & $-781 \%$ \\
\hline August & 0.03 & 0.44 & 6.64 & $-19,375 \%$ & 0.10 & 0.95 & 7.22 & $-7,007 \%$ \\
\hline September & 0.12 & 1.75 & 7.01 & $-5,909 \%$ & 0.07 & 0.78 & 6.65 & $-8,995 \%$ \\
\hline October & 3.44 & 4.07 & 6.51 & $-89 \%$ & 3.29 & 3.74 & 5.60 & $-70 \%$ \\
\hline
\end{tabular}

${ }^{1}$ Withdrawn from layer 15, assumed intake of pump

${ }^{2}$ Volume averaged concentration of segment

\section{Biochemical Oxygen Demand and First Order Sediment}

Ultimate carbonaceous BOD decreases through the wetland were minimal through early June. Thereafter, decreases ranged from 12 to 39 percent (fig. 19; table 12). First-order sediment organic-matter concentrations were largest in the upstream end of the wetland, where concentrations greater than $100 \mathrm{mg} / \mathrm{L}$ were present (fig. 20). Concentrations diminished rapidly in the downstream direction, consistent with large loads of particulate material in the influent that settles rapidly in the wetland. Total suspended solids (TSS) concentrations in the wetland indicated that large decreases occurred through the wetland, most likely through settling in low velocity, shallow waters, with decreases ranging from 60 to 81 percent (table 13). 
Ultimate BOD, in milligrams per liter

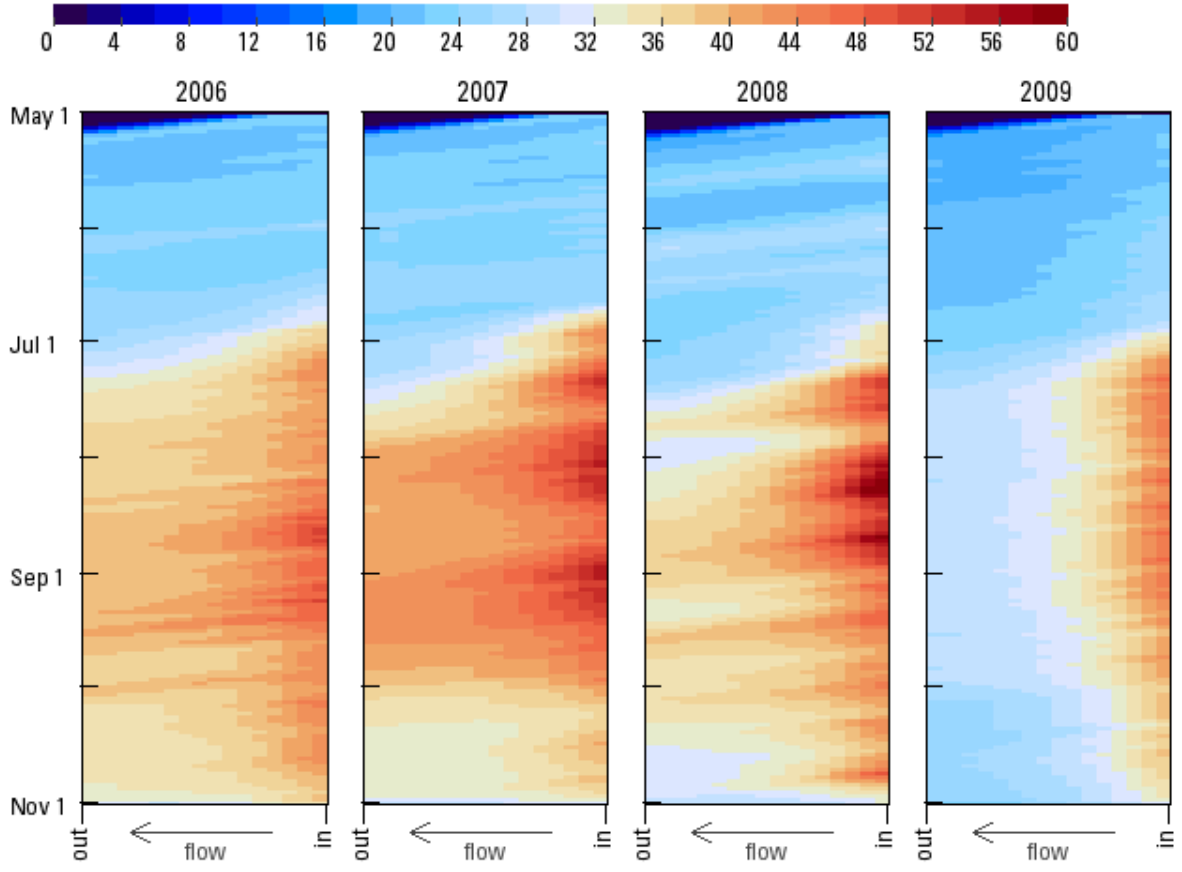

Figure 19. Graphs showing ultimate carbonaceous biochemical oxygen demand (BOD) concentrations through the wetland for the operational period (May 1-October 31) for 2006-09.

1st-order sediment, in milligrams per liter

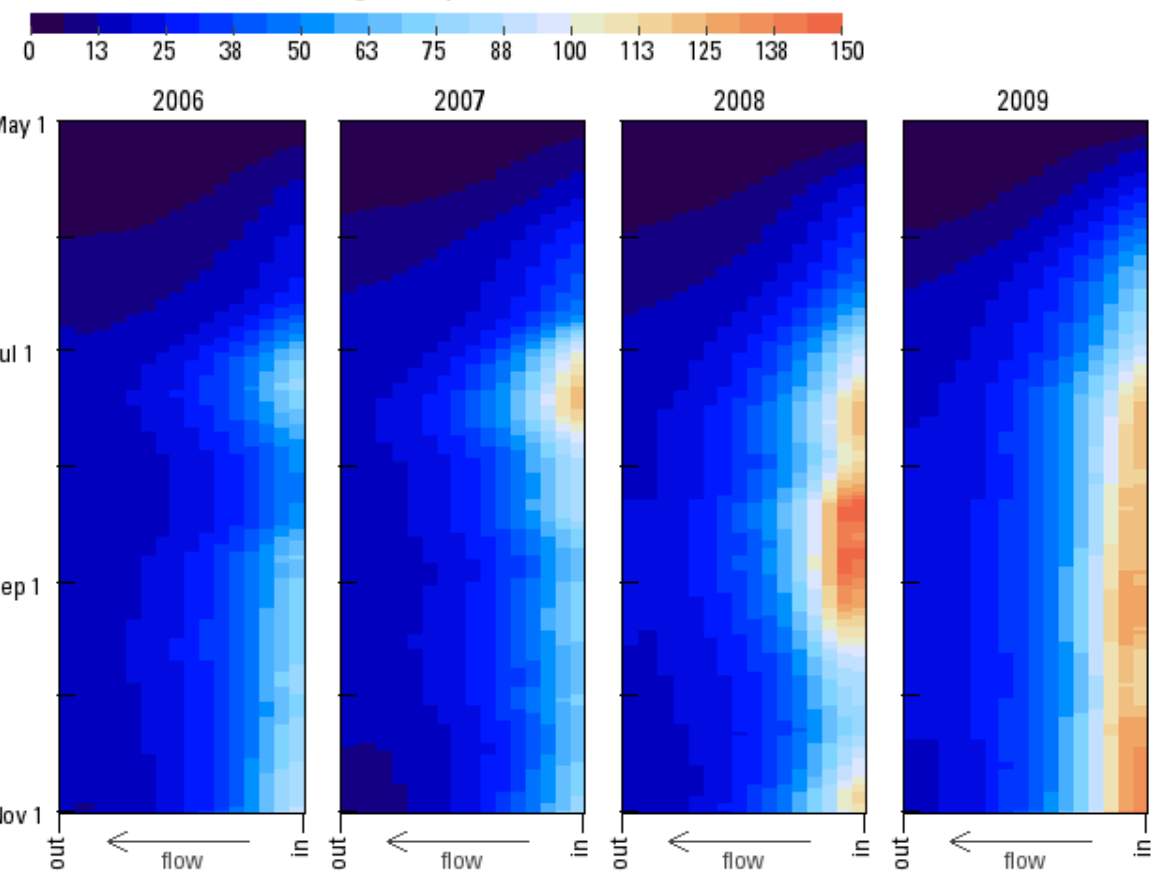

Figure 20. First-order sediment concentrations through the wetland for the operational period (May 1-October 31) for 2006-09. 
Table 12. Monthly ultimate carbonaceous biochemical oxygen demand concentrations (milligrams per liter) for the simulated wetland in the Link-Keno reach of the Klamath River.

[Results for the head and downstream end of the wetland, including percent reduction based on segments 28 and 124, are shown for 2006-09. Concentrations given in milligrams per liter.

Abbreviations: Seg., model segment]

\begin{tabular}{|c|c|c|c|c|c|c|c|c|}
\hline & \multicolumn{4}{|c|}{2006} & \multicolumn{4}{|c|}{2007} \\
\hline \multirow[t]{2}{*}{ Month } & River & \multicolumn{2}{|c|}{ Wetland } & \multirow[t]{2}{*}{$\begin{array}{c}\text { Percent } \\
\text { decrease }\end{array}$} & \multirow{2}{*}{$\begin{array}{c}\text { River } \\
\text { Seg. } 28^{1}\end{array}$} & \multicolumn{2}{|c|}{ Wetland } & \multirow[t]{2}{*}{$\begin{array}{c}\text { Percent } \\
\text { decrease }\end{array}$} \\
\hline & Seg. $28^{1}$ & Seg. $111^{2}$ & Seg. $124^{2}$ & & & Seg. $111^{2}$ & Seg. $124^{2}$ & \\
\hline June & 27.78 & 27.47 & 24.52 & $12 \%$ & 29.47 & 28.98 & 24.41 & $17 \%$ \\
\hline July & 42.03 & 41.58 & 33.84 & $20 \%$ & 48.64 & 47.75 & 32.84 & $32 \%$ \\
\hline August & 46.39 & 45.90 & 38.26 & $18 \%$ & 50.41 & 50.17 & 40.98 & $19 \%$ \\
\hline September & 45.89 & 45.19 & 38.58 & $16 \%$ & 49.62 & 48.39 & 41.81 & $16 \%$ \\
\hline \multirow[t]{2}{*}{ October } & 42.70 & 41.75 & 35.19 & $18 \%$ & 38.83 & 38.06 & 33.52 & $14 \%$ \\
\hline & \multicolumn{4}{|c|}{2008} & \multicolumn{4}{|c|}{2009} \\
\hline \multirow[t]{2}{*}{ Month } & River & \multicolumn{2}{|c|}{ Wetland } & $\begin{array}{c}\text { Percent } \\
\text { decrease }\end{array}$ & River & \multicolumn{2}{|c|}{ Wetland } & $\begin{array}{c}\text { Percent } \\
\text { decrease }\end{array}$ \\
\hline & Seg. $28^{1}$ & Seg. $111^{2}$ & Seg. $124^{2}$ & & Seg. $28^{1}$ & Seg. $111^{2}$ & Seg. $124^{2}$ & \\
\hline June & 28.97 & 28.53 & 24.87 & $14 \%$ & 27.32 & 26.81 & 21.70 & $21 \%$ \\
\hline July & 46.43 & 45.18 & 29.26 & $37 \%$ & 45.31 & 43.19 & 27.58 & $39 \%$ \\
\hline August & 55.92 & 53.82 & 35.82 & $36 \%$ & 47.16 & 44.49 & 29.02 & $38 \%$ \\
\hline September & 44.75 & 43.91 & 35.52 & $21 \%$ & 44.06 & 41.75 & 28.63 & $35 \%$ \\
\hline October & 41.83 & 40.58 & 32.51 & $22 \%$ & 38.52 & 37.03 & 25.64 & $33 \%$ \\
\hline
\end{tabular}

${ }^{1}$ Withdrawn from layer 15 , assumed intake of pump

${ }^{2}$ Volume averaged concentration of segment 
Table 13. Monthly total suspended sediment concentrations (milligrams per liter) for the simulated wetland in the Link-Keno reach of the Klamath River.

[Results for the head and downstream end of the wetland, including percent reduction based on segments 28 and 124, are shown for 2006-09. Concentrations given in milligrams per liter. Abbreviations: Seg., model segment]

\begin{tabular}{|c|c|c|c|c|c|c|c|c|}
\hline \multirow{3}{*}{ Month } & \multicolumn{4}{|c|}{2006} & \multicolumn{4}{|c|}{2007} \\
\hline & \multirow{2}{*}{$\begin{array}{c}\text { River } \\
\text { Seg. } \mathbf{2 8}^{1}\end{array}$} & \multicolumn{2}{|c|}{ Wetland } & \multirow[t]{2}{*}{$\begin{array}{c}\% \% \\
\text { Decrease }\end{array}$} & \multirow{2}{*}{$\frac{\text { River }}{\text { Seg. } 28^{1}}$} & \multicolumn{2}{|c|}{ Wetland } & \multirow[t]{2}{*}{$\begin{array}{c}\text { Percent } \\
\text { decrease }\end{array}$} \\
\hline & & Seg. $111^{2}$ & Seg. $124^{2}$ & & & Seg. $111^{2}$ & Seg. $124^{2}$ & \\
\hline June & 9.22 & 8.80 & 3.72 & $60 \%$ & 10.09 & 9.49 & 3.50 & $65 \%$ \\
\hline July & 12.05 & 11.35 & 4.17 & $65 \%$ & 16.95 & 15.78 & 4.23 & $75 \%$ \\
\hline August & 12.55 & 11.69 & 3.94 & $69 \%$ & 13.64 & 12.77 & 4.00 & $71 \%$ \\
\hline September & 12.45 & 11.54 & 3.82 & $69 \%$ & 12.09 & 10.85 & 3.51 & $71 \%$ \\
\hline \multirow[t]{2}{*}{ October } & 11.07 & 10.05 & 2.70 & $76 \%$ & 8.62 & 7.87 & 2.08 & $76 \%$ \\
\hline & \multicolumn{4}{|c|}{2008} & \multicolumn{4}{|c|}{2009} \\
\hline \multirow[t]{2}{*}{ Month } & River & \multicolumn{2}{|c|}{ Wetland } & $\begin{array}{c}\text { Percent } \\
\text { decrease }\end{array}$ & River & \multicolumn{2}{|c|}{ Wetland } & $\begin{array}{c}\text { Percent } \\
\text { decrease }\end{array}$ \\
\hline & Seg. $28^{1}$ & Seg. $111^{2}$ & Seg. $124^{2}$ & & Seg. $28^{1}$ & Seg. $111^{2}$ & Seg. $124^{2}$ & \\
\hline June & 10.29 & 9.66 & 3.75 & $64 \%$ & 10.64 & 10.00 & 3.78 & $65 \%$ \\
\hline July & 18.70 & 17.41 & 4.30 & $77 \%$ & 19.72 & 17.97 & 4.59 & $77 \%$ \\
\hline August & 21.72 & 19.71 & 4.82 & $78 \%$ & 20.31 & 18.13 & 4.60 & $77 \%$ \\
\hline September & 13.21 & 12.03 & 3.69 & $72 \%$ & 18.09 & 16.20 & 4.37 & $76 \%$ \\
\hline October & 12.44 & 11.34 & 2.69 & $78 \%$ & 21.76 & 20.11 & 4.03 & $81 \%$ \\
\hline
\end{tabular}

${ }^{1}$ Withdrawn from layer 15, assumed intake of pump

${ }^{2}$ Volume averaged concentration of segment 
$\mathrm{pH}$

$\mathrm{pH}$ values increased through the wetland for all years and all months. While inflow $\mathrm{pH}$ values ranged from approximately 8.0 to 10.0 , outflow values ranged from approximately 9.0 to 11.0 (fig. 21). Although some algal photosynthesis occurred in the wetlands, it is likely that the increase in $\mathrm{pH}$ is accounted for primarily by photosynthetic uptake and use of dissolved inorganic carbon by macrophytes.

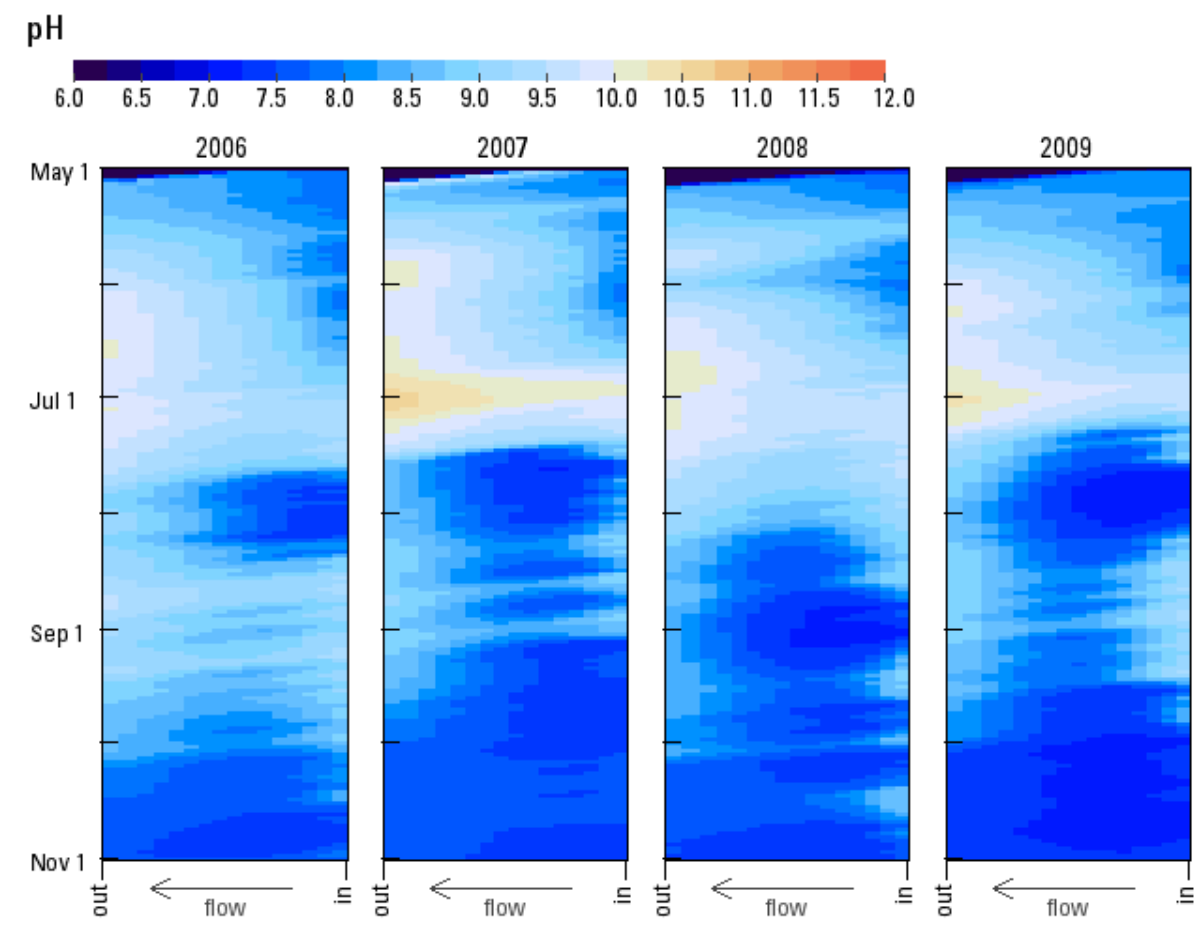

Figure 21. Graphs showing pH values through the wetland for the operational period (May 1-October 31) for 2006-09. 


\section{Discussion}

Wetland

Simulation of water-quality constituents through a wetland adjacent to the Link-Keno reach of the Klamath River generally showed that wetland features and processes could be modeled effectively with CE-QUAL-W2. These simulations, when compared with literature values and simpler wetland models, produced similar results. Also, the incorporation of a wetland in the existing Keno Reservoir model grid enabled the assessment of water-quality impacts associated with wetland operations. While a wetland in the Miller Island area was modeled in this exercise, wetlands at other locations and in other configurations could be examined.

The wetland produced a positive benefit for riverine water quality. Inorganic and organic particulate matter concentrations were notably decreased. Simulated first-order sediment organic matter accumulation confirms that the wetland settled a large fraction of particulate matter in the upper half of the wetland. Nutrient transforms, as well as algae uptake and sedimentation (organic forms), led to lower concentrations at the downstream end. Dissolved oxygen concentrations were at or near saturation in wetland effluent, consistent with values reported by Kadlec and Wallace (2009). Ultimate carbonaceous BOD values decreased modestly, but within the range of literature reported values (Crites and Tchobanoglous, 1998). Decreases in total nitrogen and total phosphorus agreed with identified removal (Crites and Tchobanoglous, 1998; Mitsch and Gosselink, 2007), as did ammonia decreases (Kadlec and Wallace, 2009). The modest change in nitrate was within the range identified by Kadlec and Wallace (2009). Total suspended solids decreases through the wetland also were comparable to documented removal (Crites and Tchobanoglous, 1998; Mitsch and Gosselink, 2007).
Chlorophyll $a$ and concentrations of the individual algae groups show that BGA was almost completely removed in the wetland, and while the "other" algae group increased through the wetland later in the season, such increases were small as a relative contribution. Although literature on specific algae species removal through wetlands are limited, Lin and others (2003) identified that a free water surface wetland was highly effective at decreasing phytoplankton populations, as represented in chlorophyll $a$ decreases ( 88 percent), attributing such decreases to contributions from macrophyte light attenuation. No shading was applied to the wetland in this scenario, and water temperature showed a slight increase (approximately $2.1^{\circ} \mathrm{C}$ average) through the wetland system.

Certain constituents showed little or no change through the system. Refractory and nonreactive materials (for example, refractory dissolved organic matter as reflected in DOC and total dissolved solids) showed little or no decrease through the wetland, consistent with Coveney and others (2002). With travel times of approximately 4-5 days, there was little opportunity for these constituents to change.

Model results suggested that the wetland produced a background concentration for several constituents, and that little removal can occur if influent concentrations are less than that background level. For much of the operation season (May-October), influent POC concentrations were variable and ranged from 1.0 to $5.0 \mathrm{mg} / \mathrm{L}$, whereas effluent values were relatively stable on the order of $0.5-1.0 \mathrm{mg} / \mathrm{L}$. These results suggest a background production of POC from the wetland of $0.5-1.0 \mathrm{mg} / \mathrm{L}$. Examining labile and refractory particulate organic matter (LPOM and RPOM, respectively) and total suspended solids, similar well-defined background levels were identified. LPOM and RPOM inputs to the wetland ranged from approximately 1.0 to 7.0 and 0.5 to $1.5 \mathrm{mg} / \mathrm{L}$, respectively; outflows were nearly constant at 1.5 and $0.5 \mathrm{mg} / \mathrm{L}$, respectively. Total suspended solids inflow concentrations ranged from 6.0 to 
$16 \mathrm{mg} / \mathrm{L}$, and outflow concentrations from 2.0 to $4.0 \mathrm{mg} / \mathrm{L}$. Simulated values from the Klamath River (upstream) and through the wetland are shown for a representative year in figure 22. Decreases through the wetland for particulate organic matter, with the exception of RPOM, were comparable with Coveney and others (2002) for particulate matter removal. Background levels for ammonia and BGA were essentially 0 , because outflow values were generally at or near zero for the majority of the operation season.

The interaction among water-quality constituents and conditions in the wetland differed from the river for many reasons, importantly shallow depth and slow velocities. Shallow depth allows extensive vegetation growth. Aquatic macrophytes drive many of the feedback relationships between the inorganic, organic, and physical water-quality constituents. Aquatic macrophyte growth in the wetland removes inorganic nutrients from the water column, influences $\mathrm{pH}$ and water temperature trends, and contributes or removes dissolved oxygen from the system during photosynthesis and respiration, respectively. Aquatic macrophyte senescence supplies organic matter and nutrients to the wetland; associated decay and transformation processes also affect dissolved oxygen concentrations. A notable finding was that phosphorous can limit algae growth in the wetland for periods of time. Additionally, the shallow nature of the wetland led to dissolved oxygen levels near saturation through more effective reaeration and photosynthesis of aquatic vegetation. These values provided an environment conducive to nitrification and organic matter oxidation, and with large firstorder sediment accumulations may provide a mechanism to support denitrification in anoxic sediments. Denitrification commonly occurs in systems with considerable dissolved oxygen in surface waters, but oxygen gradients between surface waters and bottom sediments. These conditions allow nitrification to proceed in surface waters, in addition to supplying nitrate to diffuse into anoxic sediments where denitrification occurs (Wetzel, 2001). 

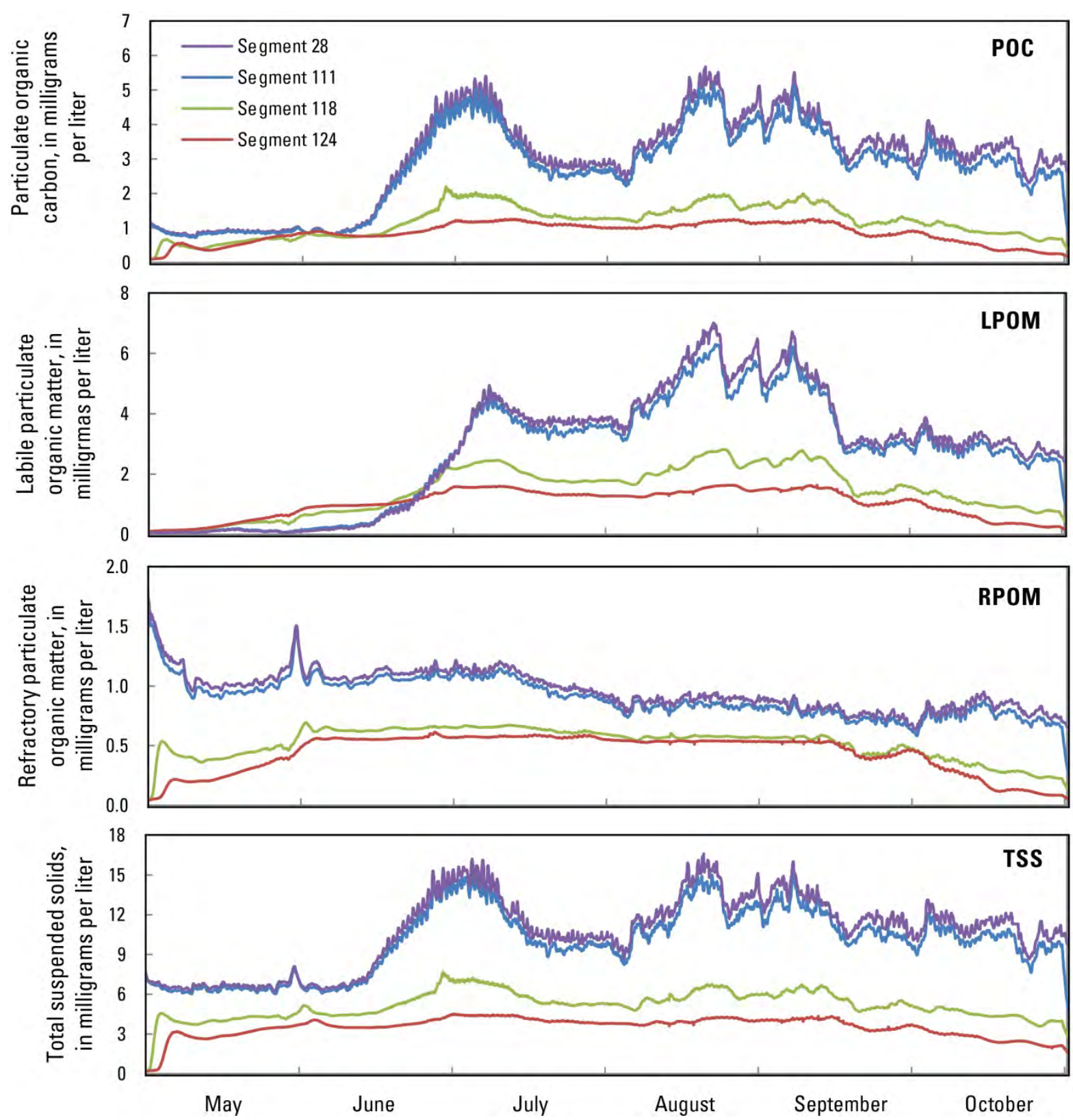

Figure 22. Graphs showing particulate organic carbon (POC), labile particulate organic matter (LPOM), refractory particulate organic matter (RPOM), and total suspended solids (TSS) in the Klamath River (segment 28 at $2.0 \mathrm{~m}$ below the water surface) and through the wetland (segments 111, 118, 124; in model layer 6) for the operational period (May 1-October 31) for 2006. 


\section{Link-Keno Reach of the Klamath River}

In addition to transformations and water quality in the wetland, downstream water-quality implications in the river also were examined. While a continuous flow of $5.66 \mathrm{~m}^{3} / \mathrm{s}\left(200 \mathrm{ft}^{3} / \mathrm{s}\right)$ was diverted through the wetland, conditions in the river were only modestly affected between the diversion point (segment 28) and the return point (segment 45). In general, poor water-quality conditions in the river remained poor through this reach. Below the wetland return point, the benefits associated with improved water-quality discharge from the wetland were often observable, but were moderated by the large river volume. During the operation season, flows in the river ranged from approximately 15 to greater than $40 \mathrm{~m}^{3} / \mathrm{s}$ (500 to greater than $\left.1,400 \mathrm{ft}^{3} / \mathrm{s}\right)$ and were highly variable, but were typically around $25 \mathrm{~m}^{3} / \mathrm{s}\left(880 \mathrm{ft}^{3} / \mathrm{s}\right)$ during summer periods. This translates into a wetland discharge of slightly greater than 20 percent of the river flow. Thus, downstream water quality was largely affected by waters that remained in the Link-Keno reach, and improved water quality in wetland discharge, while beneficial, had a modest effect.
Results for dissolved oxygen, BGA, particulate organic carbon, and inorganic nutrients are shown in figure 23. The wetland produced improvements of up to $1 \mathrm{mg} / \mathrm{L}$ for dissolved oxygen, but modest improvements in BGA and particulate organic carbon. These two constituents are most likely overwhelmed by upstream loads of BGA and also may reflect BGA and other algal dynamics between the wetland discharge and Keno Dam. Ammonia and nitrate plus nitrite were reflective of overall improved oxygen conditions, suggesting that wetland returns allowed some level of nitrification to proceed (total inorganic nitrogen was not remarkably different, just the forms of inorganic nitrogen). Concentrations in orthophosphorus were only modestly lower. These results suggest that multiple wetlands of different sizes and at different locations may provide a greater benefit to downstream Klamath River reaches. 

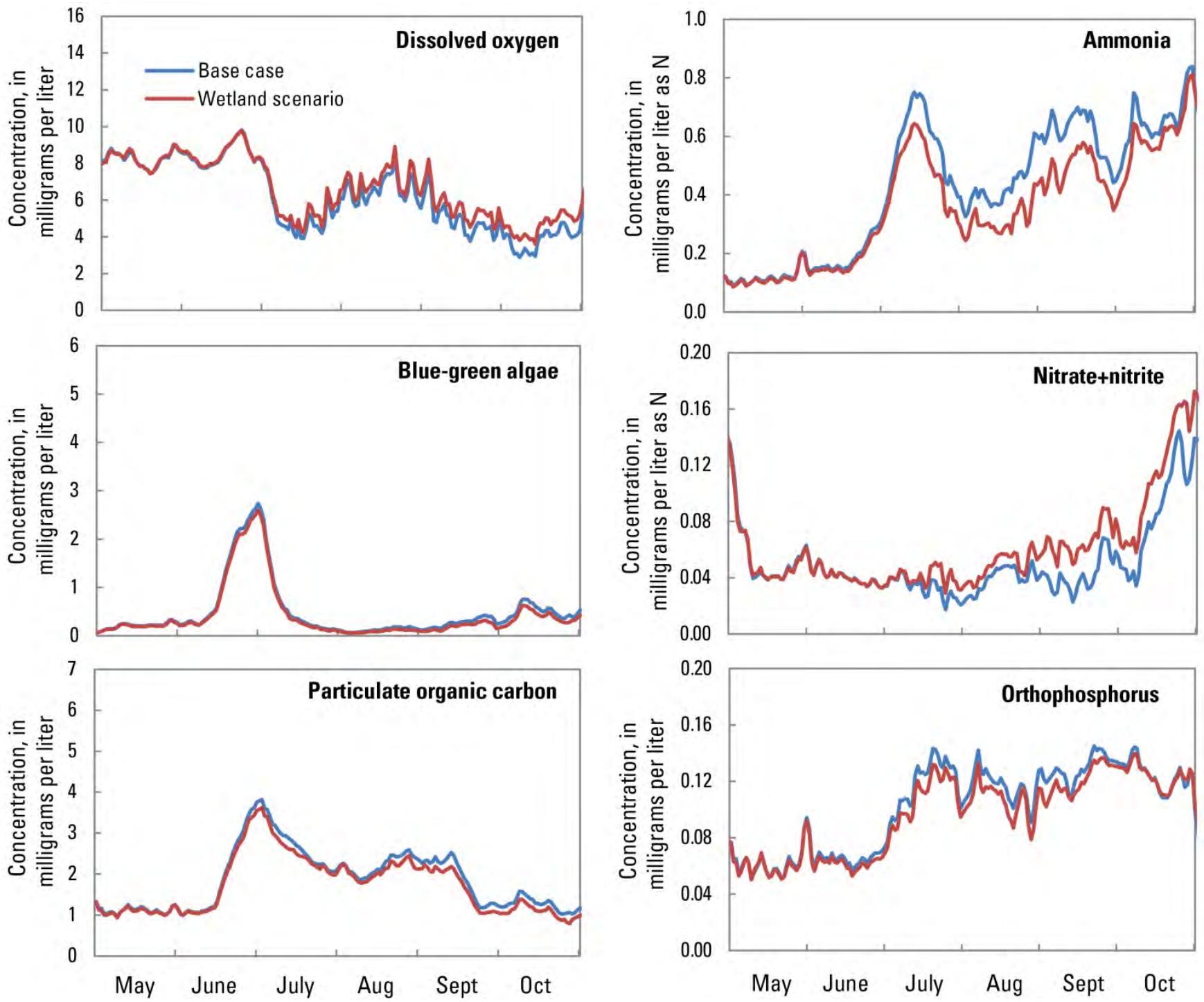

Figure 23. Graphs showing dissolved oxygen, blue-green algae, particulate organic carbon, ammonia, nitrate+nitrite, and orthophosphorus concentrations at Keno Dam, model segment 103. Base case and wetland scenario results are plotted for year 2006.

\section{Future Model \\ Development and Application}

During the construction and application of this new wetland model, several suggestions were identified to improve model representation, identify data needs, and explore other potential wetland locations, configurations, and operations in the study area. Although some may overlap into multiple categories, the general categories are model modifications, data/information needs, and applications.

\section{Model Modifications}

The following model modifications would require changes to the existing source code for CE-QUAL-W2, and include:

- Phytoplankton representation by waterbody: Multiple phytoplankton types and individual attributes currently can be specified for the entire model grid (global representation). The ability to apply discrete phytoplankton attributes on a waterbody-by-waterbody basis, as the macrophyte logic is represented, would 
allow wetland attributes to be modeled independently of phytoplankton in other parts of the model. The same algae may behave differently in a wetland environment compared to a riverine environment, for example, so allowing the settling rate to vary for the same algal group from one waterbody to the next might be useful.

- Extended macrophyte logic: The current representation of macrophytes is appropriate for low-density analyses. However, for high density macrophytes in a wetland setting, a different approach would be useful. The layer-to-layer growth and fraction of segment occupied are useful starting points. Development of an emergent vegetation element (for example, bulrush, cattail, or other emergent vegetation) would allow for a more appropriate plant assemblage, as well as a shading component that would be useful. Roughness/drag logic could be revisited to determine if refinement may be beneficial. Interaction among plant communities - phytoplankton, epiphyton, macrophytes, and emergent vegetationfrom a shade perspective, as well as density, could be considered.

- Initial conditions on a segment-bysegment basis for first-order sediment conditions: Organic (and inorganic) sediment accumulation at the inlet vicinity of treatment wetlands is a common occurrence. Furthermore, the distribution of settled material throughout a wetland, particular through time, is not typically uniform. Incorporating a method to accommodate spatially distributed organic sediments would allow a wider range of problems to be assessed with the model.

\section{Information/Data Needs}

Beyond the basic suggestions for additional data collection at site specific wetland environments, there are specific elements that would be beneficial regarding wetlands applications of the model, including:

- Vegetation communities and distributions: In this application a single vegetation community is assumed to represent all plants in a wetland. Quantification of site specific desired wetland plants and their spatial and temporal distributions would be useful.

- Wetland seepage loss: In the current model, seepage loss was not explored. The groundwater table in the area is high and seepage losses may be modest (Marshall Gannett, U.S. Geological Survey, oral commun., 2014). However, identifying a range of potential local seepage loss that could be incorporated into future analyses would be beneficial. Fate of seepage loss, an unquantified process in the project area, would be another area of investigation.

- Mercury processes: Recent discussions regarding wetlands as potential prescriptions to improve water quality have identified wetlands as environments that can produce methylmercury, a form that readily accumulates in biota. This need for data should be assessed to determine the potential for mercury methylation in the study area.

\section{Applications}

Further application of the existing model could be used to provide information on the design, location, size, and other treatment wetland attributes and their efficacy and impact on the Klamath River. This information would be transferable to other areas where treatment wetlands might be needed.

- Configuration: Treatment wetlands can take on a variety of shapes, sizes, depths, flow rates, circulation patterns, outflow point(s), wetland plant communities, open water areas, and other factors. 
Application of the model to other identified configurations could assess the utility and efficacy of these design features.

- Locations: Application of the model to wetlands located in other areas of the Link-Keno reach or the larger Klamath and Lost River Basins would lend insight into the potential benefits of locating wetlands in particular targeted areas.

- Multiple wetlands: Because potential treatment wetland areas are limited, identifying the value of multiple wetlands at different locations would provide useful information regarding potential implications for improving water quality the Link-Keno reach of the Klamath River and farther downstream.

- Scaling: One aspect of the model that may prove useful is to test assumptions on wetlands of different sizes, such as pilot scale wetlands versus full scale wetlands. Performance metrics could be compared (for example, removal fractions) and the model could assess factors such as residence time, depths, and other elements.

\section{Link-Keno Model Test with Year 2011}

Testing a calibrated model for years that were not part of the calibration can be used to investigate how robust the model is in predicting water-quality conditions under new conditions. A particularly rigorous test is to select a year in which conditions were notably different than in the calibration years. Because water-quality conditions in 2011 were unusually good, that year was selected for model testing.

In recent years, it is typical for dissolved oxygen concentrations in the Link-Keno reach to be above the relevant water-quality standard in late winter and early spring, then decrease to hypoxic or anoxic conditions in summer and slowly recover through the autumn to complete a repeating annual cycle (fig. 24). This pattern held true for 2006-09, the years for which the LinkKeno models were developed. In 2011, the summertime decrease in dissolved oxygen concentrations still occurred; however, the decrease was minor, and overall dissolved oxygen concentrations were noted to be good (Steensland, 2012). One of the dissolved oxygen standards in this reach is the 30-day mean minimum of $6.5 \mathrm{mg} / \mathrm{L}$ standard (Oregon Department of Environmental Quality, 2011), which is plotted with the dissolved oxygen data in figure 24 for comparison.

The Link-Keno model was developed for year 2011 to serve three purposes: (1) to test the existing model in a year with different waterquality conditions, (2) to investigate the factors that produced good water-quality conditions in that year, and (3) to expand the number of years with working models for the Link-Keno reach of the Klamath River. 


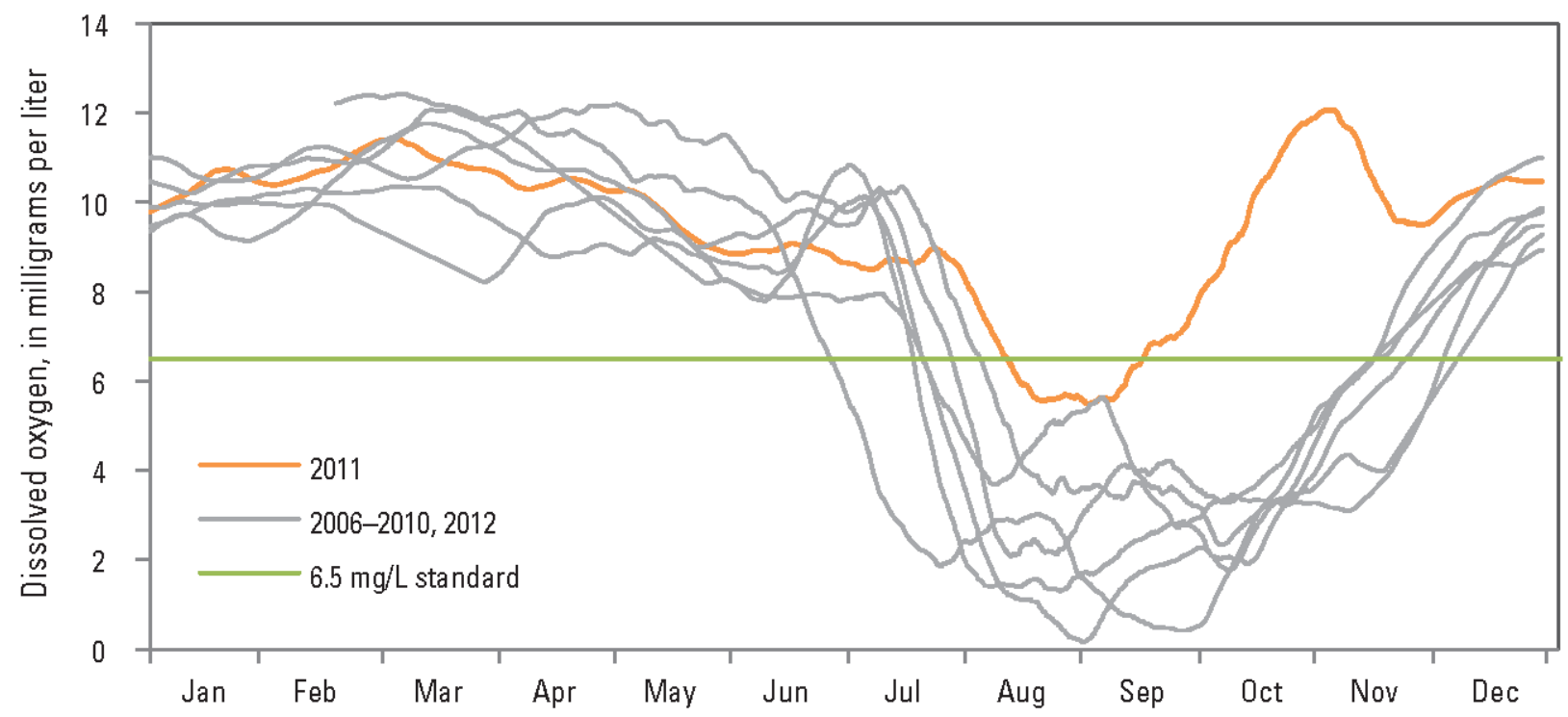

Figure 24. Graph showing dissolved oxygen concentration at Miller Island at $1 \mathrm{~m}$ depth, for 2006-12. Values are the 30-day moving average of hourly measured data. The 30-day dissolved oxygen standard also is plotted.

\section{Methods}

For this test, most components of the previously developed Link-Keno model (Sullivan and others, 2011, 2013a) were used without alteration for the 2011 model, including the model grid and calibrated parameters. Updates were made to the input and calibration files, using data from 2011. Required information included measured data applied at the model boundary inputs and tributaries and calibration data to check the model's performance at sites along the model reach. Flow, stage, water temperature, and water-quality data were compiled from various sources. At some locations, 2011 data were plentiful, while at others 2011 data were only minimally available. Using a collection of various data sources for modeling can introduce some uncertainty to the model predictions.

\section{Meteorological and Flow Data}

Most meteorological data for model input were obtained from the Klamath Falls airport (site KLMT). These data included air temperature, dew point temperature, wind speed, wind direction, precipitation, and cloud cover at hourly intervals. Cloud cover was converted to CE-QUAL-W2 model units as described in
Sullivan and others (2011). The model also requires the temperature of precipitation, which was assumed equal to air temperature, except when air temperature was below $0{ }^{\circ} \mathrm{C}$; for those periods, precipitation temperature was set to zero. Hourly solar radiation data were obtained from the Klamath Falls Agrimet station (site KFLO).

Year 2011 flow data for model input were obtained from USGS and Bureau of Reclamation gages and from point source discharge monitoring reports (DMRs) submitted to Oregon Department of Environmental Quality (ODEQ). The main inflow to the Link-Keno reach was the flow from Upper Klamath Lake through Link River (fig. 7). At times, part of Link River flow was routed through the Westside Power Canal. Daily Westside Power Canal data were obtained from PacifiCorp and added to half-hourly USGS gaged flows, measured just upstream of the Westside Canal at USGS streamgage 11507500, to obtain total Link River flow. Other inflows to the system, with data at daily intervals, included the Lost River Diversion Channel, Klamath Straits Drain, Klamath Falls wastewater treatment plant (WWTP), and South Suburban WWTP (fig. 7). Columbia Forest Products was an inflow 
in the 2006-09 model, but did not discharge to the Klamath River in 2011.

The largest outflow from the Link-Keno system was the Klamath River at Keno Dam; that flow was measured at the USGS streamgage downstream of the dam, with data collected at one-half-hourly intervals. Other withdrawals from the system included Lost River Diversion Channel (in summer), North Canal, and Ady Canal, with daily measurements available from the Bureau of Reclamation.

\section{Water Temperature and Water-Quality Data}

Water-quality data from discrete grab samples and from multiparameter instruments were obtained from several agencies or groups, including the USGS, Bureau of Reclamation, ODEQ, and Klamath Tribes (table 14). Some data were collected as part of the Klamath Hydroelectric Settlement Agreement (KHSA; Watercourse Engineering, Inc., 2012). Only a brief summary of the water-quality datacollection methods are described here, because methods generally were similar to those used in previous model development (Sullivan and others, 2011).
Grab samples were collected from the water column and typically were analyzed for a number of constituents such as total and dissolved nutrients, organic matter, and algae. When more than one source of data was available for a constituent for the same site, all data were plotted together for initial analysis. Typically, the dataset with the most frequent data was used to construct the input file or calibration dataset, as long as its temporal pattern was consistent with data from the other sources. Data from other sources were used to fill in data gaps for periods with less frequent collection.

Multiparameter sonde data were largely from instruments deployed at fixed depth that collected continuous (hourly or one-half-hourly) water temperature, specific conductance, $\mathrm{pH}$, and dissolved oxygen data. When visiting the continuous instrument sites for maintenance or sometimes for grab samples, vertical profiles of sonde measurements also were collected and represent another dataset for calibration. Sondes were deployed and maintained by the Bureau of Reclamation during this time period. The USGS processed the data to correct for fouling and instrument drift (methods modified from Wagner and others, 2006).

Table 14. Location of water-quality monitors and grab-sample sites and type of data used for the development of model input files or calibration checks for the calendar year 2011 model in the upper Klamath River, Oregon-continued

[Abbreviations: Reclamation . Bureau of Reclamation; USGS, U.S. Geological Survey; ODEQ, Oregon Department of Environmental Quality; PC, PacifiCorp; I, model input; C, calibration check; m, meter; S, data from multiparameter sonde; G, grab sample; KHSA, Klamath Hydroelectric Settlement Agreement]

\begin{tabular}{|c|c|c|c|c|c|}
\hline Site Name & Source & Site ID & Latitude Longitude & Constituents & Use \\
\hline Pelican Marina & $\begin{array}{l}\text { Klamath } \\
\text { Tribes }\end{array}$ & PM & $\begin{array}{l}42^{\circ} 14^{\prime} 16.892^{\prime \prime} \\
-121^{\circ} 48^{\prime} 37.341^{\prime \prime}\end{array}$ & G & I \\
\hline Link Dam & $\begin{array}{l}\text { Reclamation, } \\
\text { KHSA }\end{array}$ & KR2544 & $\begin{array}{l}42^{\circ} 14^{\prime} 1.75^{\prime} \\
-121^{\circ} 48^{\prime} 8.6^{\prime}\end{array}$ & G & I \\
\hline Link River below Keno Canal & $\begin{array}{l}\text { Reclamation, } \\
\text { USGS }\end{array}$ & 11507501 & $\begin{array}{l}42^{\circ} 13^{\prime} 10^{\prime \prime} \\
-121^{\circ} 47^{\prime} 25^{\prime}\end{array}$ & $S$ & I \\
\hline
\end{tabular}


Table 14. Location of water-quality monitors and grab-sample sites and type of data used for the development of model input files or calibration checks for the calendar year 2011 model in the upper Klamath River, Oregon-continued

[Abbreviations: Reclamation . Bureau of Reclamation; USGS, U.S. Geological Survey; ODEQ, Oregon Department of Environmental Quality; PC, PacifiCorp; I, model input; C, calibration check; m, meter; S, data from multiparameter sonde; G, grab sample; KHSA, Klamath Hydroelectric Settlement Agreement]

\begin{tabular}{|c|c|c|c|c|c|}
\hline Site Name & Source & Site ID & Latitude Longitude & Constituents & Use \\
\hline Link River at mouth & ODEQ & 10768 & $\begin{array}{l}42^{\circ} 13^{\prime} 08 ” \\
-121^{\circ} 47^{\prime} 18^{\prime \prime}\end{array}$ & G & I \\
\hline $\begin{array}{l}\text { Klamath Falls wastewater treatment } \\
\text { plant outfall }\end{array}$ & ODEQ & 13174 & $\begin{array}{l}42^{\circ} 12^{\prime} 57^{\prime \prime} \\
-121^{\circ} 46^{\prime} 36^{\prime \prime}\end{array}$ & G & I \\
\hline $\begin{array}{l}\text { South Suburban Sanitation District } \\
\text { outfall }\end{array}$ & ODEQ & 13316 & $\begin{array}{l}42^{\circ} 11^{\prime} 51^{\prime \prime} \\
-121^{\circ} 46^{\prime} 13^{\prime \prime}\end{array}$ & G & I \\
\hline $\begin{array}{l}\text { Lost River Diversion Channel near } \\
\text { Klamath River }\end{array}$ & $\begin{array}{l}\text { Reclamation, } \\
\text { USGS }\end{array}$ & 421015121471800 & $\begin{array}{l}42^{\circ} 10^{\prime} 15^{\prime \prime} \\
-121^{\circ} 47^{\prime} 18^{\prime \prime}\end{array}$ & S & I \\
\hline Lost River Diversion Dam & Reclamation & K-5 & $\begin{array}{l}42^{\circ} 09^{\prime} 18^{\prime \prime} \\
-121^{\circ} 39^{\prime} 46^{\prime \prime}\end{array}$ & G & $\mathrm{I}$ \\
\hline $\begin{array}{l}\text { Klamath River at Miller Island Boat } \\
\text { Ramp [top] }\end{array}$ & $\begin{array}{l}\text { Reclamation, } \\
\text { USGS }\end{array}$ & 420853121505500 & $\begin{array}{l}42^{\circ} 08^{\prime} 53^{\prime \prime} \\
-121^{\circ} 50^{\prime} 55^{\prime \prime}\end{array}$ & $S$ & $\mathrm{C}$ \\
\hline $\begin{array}{l}\text { Klamath River at Miller Island Boat } \\
\text { Ramp [bottom] }\end{array}$ & $\begin{array}{l}\text { Reclamation, } \\
\text { USGS }\end{array}$ & 420853121505501 & $\begin{array}{l}42^{\circ} 08^{\prime} 53^{\prime \prime} \\
-121^{\circ} 50^{\prime} 55^{\prime}\end{array}$ & S & C \\
\hline Miller Island & $\begin{array}{l}\text { Reclamation, } \\
\text { KHSA }\end{array}$ & KR2460 & $\begin{array}{l}42^{\circ} 08^{\prime} 53^{\prime \prime} \\
-121^{\circ} 50^{\prime} 55^{\prime \prime}\end{array}$ & G & $\mathrm{C}$ \\
\hline Klamath Strait at USBR Pump Station F & ODEQ & 10763 & $\begin{array}{l}42^{\circ} 04^{\prime} 48^{\prime \prime} \\
-121^{\circ} 50^{\prime} 27^{\prime}\end{array}$ & G & I \\
\hline Klamath Straits Drain near Hwy 97 & $\begin{array}{l}\text { Reclamation, } \\
\text { USGS }\end{array}$ & 420451121510000 & $\begin{array}{l}42^{\circ} 04^{\prime} 51^{\prime \prime} \\
-121^{\circ} 51^{\prime} 00^{\prime \prime}\end{array}$ & $S$ & I \\
\hline Klamath Straits Drain at Highway 97 & Reclamation & $\mathrm{K}-1$ & $\begin{array}{l}42^{\circ} 04^{\prime} 51^{\prime \prime} \\
-121^{\circ} 50^{\prime} 44^{\prime \prime}\end{array}$ & G & I \\
\hline $\begin{array}{l}\text { Klamath River above Keno Dam nr } \\
\text { Keno, OR [top] }\end{array}$ & $\begin{array}{l}\text { Reclamation, } \\
\text { USGS }\end{array}$ & 11509370 & $\begin{array}{l}42^{\circ} 07^{\prime} 41^{\prime \prime} \\
-121^{\circ} 55^{\prime} 44^{\prime \prime}\end{array}$ & S & $\mathrm{C}$ \\
\hline $\begin{array}{l}\text { Klamath River above Keno Dam nr } \\
\text { Keno, OR [bottom] }\end{array}$ & $\begin{array}{l}\text { Reclamation, } \\
\text { USGS }\end{array}$ & 420741121554001 & $\begin{array}{l}42^{\circ} 07^{\prime} 41^{\prime \prime} \\
-121^{\circ} 55^{\prime} 44^{\prime \prime}\end{array}$ & S & $\mathrm{C}$ \\
\hline Klamath River above Keno Dam & ODEQ & 10765 & $\begin{array}{l}42^{\circ} 07^{\prime} 41^{\prime \prime} \\
-121^{\circ} 55^{\prime} 44^{\prime \prime}\end{array}$ & G & $\mathrm{C}$ \\
\hline
\end{tabular}


Table 14. Location of water-quality monitors and grab-sample sites and type of data used for the development of model input files or calibration checks for the calendar year 2011 model in the upper Klamath River, Oregon-continued

[Abbreviations: Reclamation . Bureau of Reclamation; USGS, U.S. Geological Survey; ODEQ, Oregon Department of Environmental Quality; PC, PacifiCorp; I, model input; C, calibration check; m, meter; S, data from multiparameter sonde; G, grab sample; KHSA, Klamath Hydroelectric Settlement Agreement]

\begin{tabular}{|c|c|c|c|c|c|}
\hline Site Name & Source & Site ID & Latitude Longitude & Constituents & Use \\
\hline Klamath River below Keno Dam & $\begin{array}{l}\text { Reclamation, } \\
\text { KHSA }\end{array}$ & KR2334 & $\begin{array}{l}42^{\circ} 08^{\prime} 03^{\prime \prime} \\
-121^{\circ} 56^{\prime} 50 ”\end{array}$ & G & $\mathrm{C}$ \\
\hline $\begin{array}{l}\text { Klamath River below Keno Dam at } \\
\text { Keno, OR }\end{array}$ & USGS & 11509500 & $\begin{array}{l}42^{\circ} 08^{\prime} 00^{\prime \prime} \\
-121^{\circ} 57^{\prime} 40^{\prime}\end{array}$ & $\mathrm{S}$ & $\mathrm{C}$ \\
\hline
\end{tabular}

\section{Water Balance}

After running the model with gaged inflows and outflows, evaporation, and precipitation, the modeled water surface elevation upstream of Keno Dam did not exactly match the measured water surface elevation. To complete the water balance, a distributed tributary was applied within the model. A distributed tributary accounts for flow measurement error and ungaged flows such as small tributaries, overland flow, or seepage loss to groundwater. The total flow in the distributed tributary was small compared to gaged flows, making up 3 percent of total inflows and 2 percent of total outflows in 2011 in this reach of the river. Measured water surface elevations just upstream of Keno Dam are plotted with the final modeled water surface elevations at the same location and dates in figure 25.

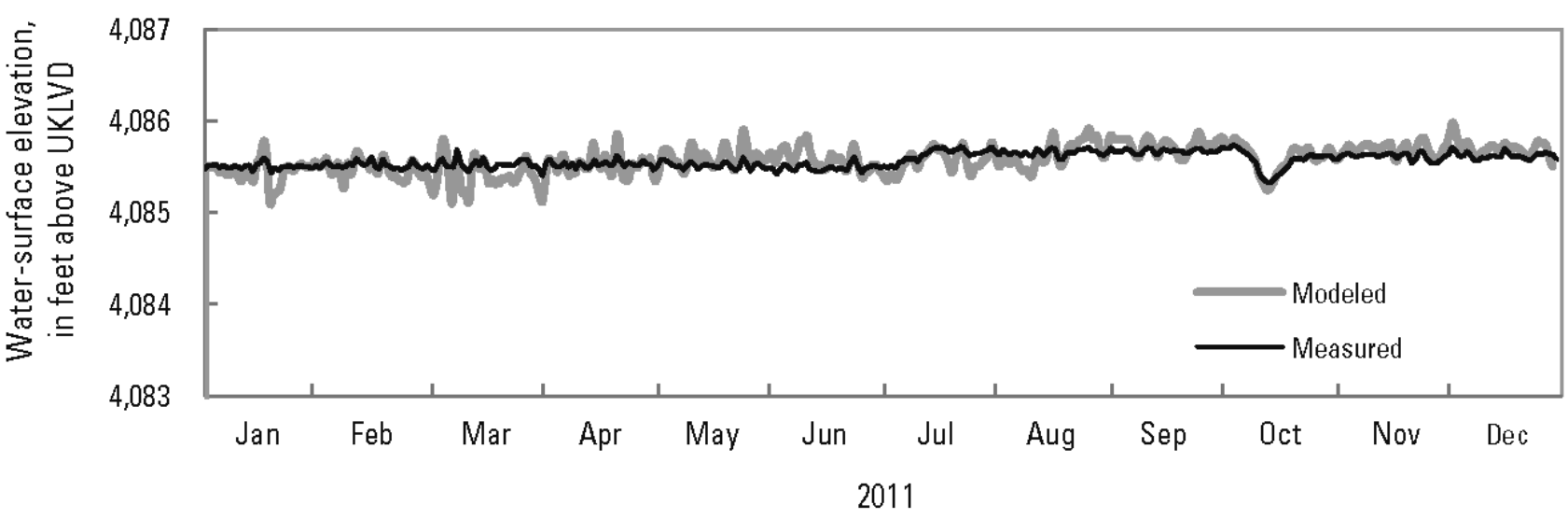

Figure 25. Graph showing daily average measured and modeled water surface elevations at Keno Dam forebay, Oregon for calendar year 2011. UKLVD, Upper Klamath Lake Vertical Datum.

\section{Model Results}

The model test with 2011 data produced results that simulated the spatial and temporal patterns of most constituents well through the reach (figs. 26-28). Despite the different pattern of dissolved oxygen in summer, many of the overall water-quality patterns were similar to those in previous years. For instance, the dissolved nitrogen species nitrate and ammonia were at their highest concentration in winter and lowest in spring; ammonia showed elevated concentrations starting in late summer, although the concentrations were smaller compared to previous years.

Error statistics comparing model results to measured data within the reach (table 15) showed 
similar or somewhat greater error for 2011, for most constituents, compared to other years. This is due in part to the fact that year 2011 was a test, not part of calibration, and also could be due to the fact that multiple datasets from different sources were used to supply input and calibration data.

The 2011 model test revealed two items in particular to be potential issues for further consideration, data collection, and model refinement:

1. Elevated dissolved oxygen and $\mathrm{pH}$, late September through early November: At this time of year in 2011, measured dissolved oxygen concentrations were elevated, up to 150 percent of saturation, indicating a large oxygen production rate from photosynthetic processes (fig. 27). In late autumn, the bluegreen algae bloom had abated, so the likely explanation is that this production was due to macrophyte photosynthesis. That activity was able to elevate the dissolved oxygen concentrations in the Klamath River because there was less competing oxygen demand from accumulated algae and particulate organic matter on the river bottom in 2011, in contrast to years with higher algal inputs in summer from Upper Klamath Lake (Sullivan and others, 2011). Measured pH was similarly elevated at that time of year (fig. 27). It appears that the model was not able to capture enough macrophyte photosynthesis in late autumn because the first temperature rate multipliers for photosynthesis for two of the macrophyte groups (parameters MT1) were likely set too high. Adjusting them downward would allow macrophytes to grow and photosynthesize under cooler conditions such as those found in late autumn of 2011. If the entire model were to be recalibrated in the future, the macrophyte temperature rate multiplier parameters should be reconsidered to make that adjustment. There may be other contributing factors to the measured dissolved oxygen patterns; for instance there may have been more macrophyte biomass in 2011 compared to other years.

2. Blue-green algae maximum concentration: With only a few data points for calibration, it is difficult to be certain, but it appears that the model did not fully capture the downstream concentration trend for blue-green algae in 2011 (fig. 29). That problem also is apparent in the particulate nitrogen and carbon results, as those measurements include algae. However, modeled chlorophyll $a$ does match measured values well in 2011. One possible reason for this is that in previous years Aphanizomenon flos-aquae was the dominant blue-green algae in the reach, so that the calibrated blue-green algae parameters were essentially those of Aphanizomenon flosaquae. In 2011, there was a substantial population of a different blue-green algae, Anabaena flos-aquae, in the reach as well (fig. 30). Anabaena flos-aquae likely has different growth, death, settling, algae/chlorophyll $a$ ratios, and other parameters than Aphanizomenon flos-aquae, and the model blue-green algae parameters are not optimized to capture the behavior of two dominant blue-green species. To address this, one option would be to split the bluegreen algae group into two groups. Some sensitivity testing showed that while changing the blue-green algae settling rate, for example, did improve the blue-green algae simulation, it had a relatively minor effect on other water-quality constituent concentrations such as dissolved oxygen.

The model performed well on year 2011 data. Information gained from testing the model in an unusual year provided insights into how the model might be updated to better capture and predict water quality over a range of conditions. All model years were not recalibrated with the information gained from the 2011 application; recalibration should involve all model years in a systematic process. 


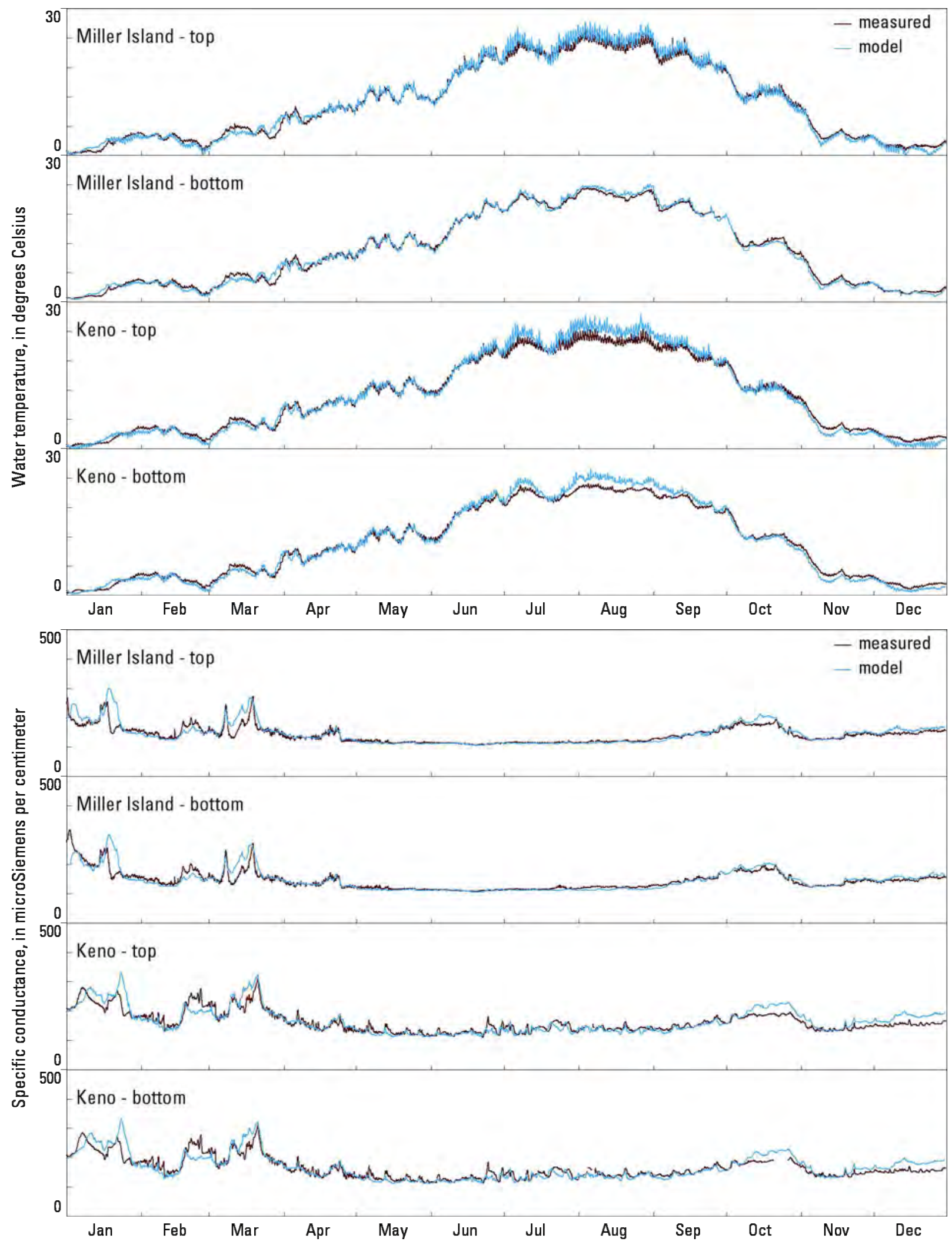

Figure 26. Graphs showing measured and modeled hourly temperature and specific conductance for calendar year 2011 for sites in the Link-Keno reach of the Klamath River, Oregon. 


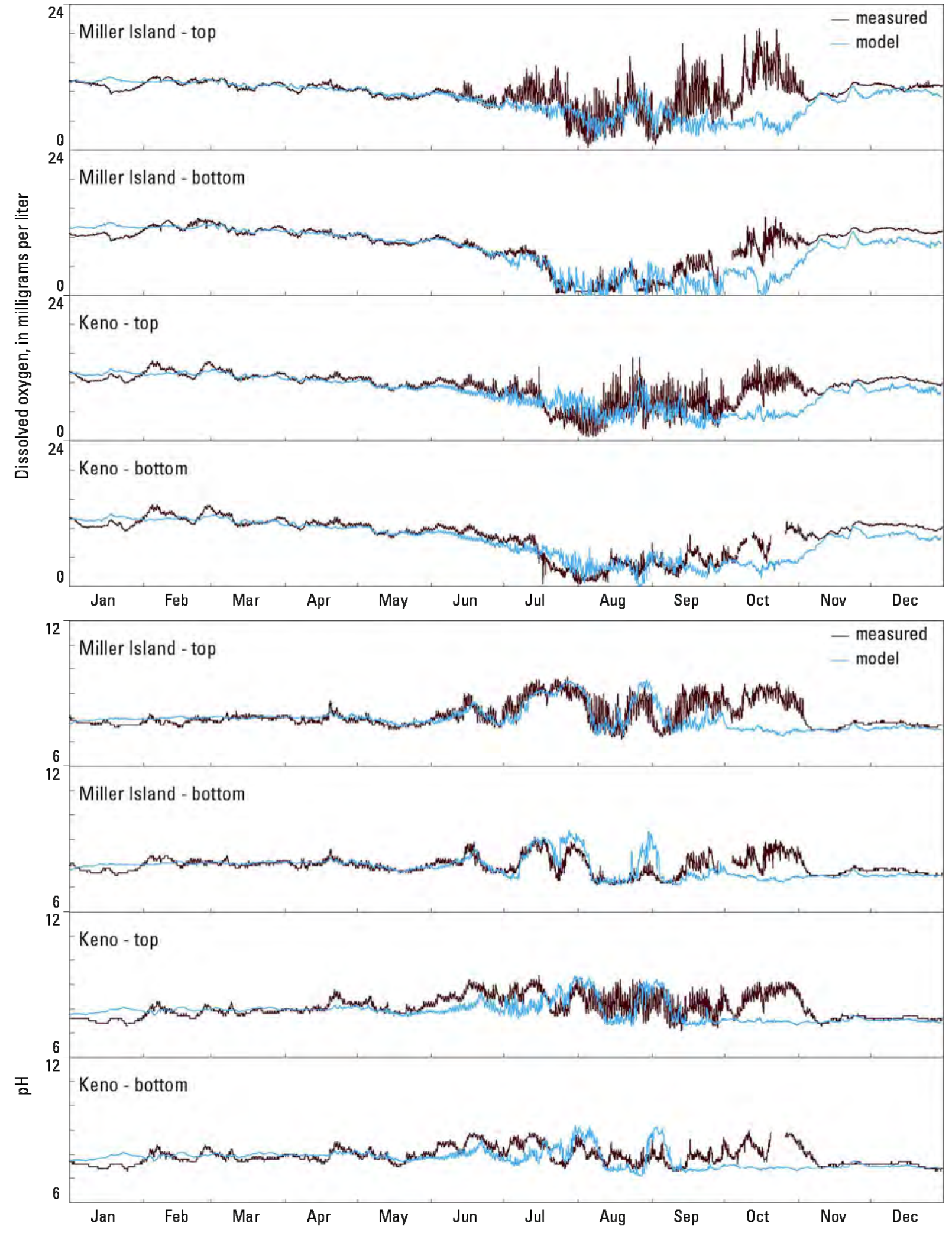

Figure 27. Graphs showing measured and modeled hourly dissolved oxygen and pH for calendar year 2011 for sites in the Link-Keno reach of the Klamath River, Oregon. 

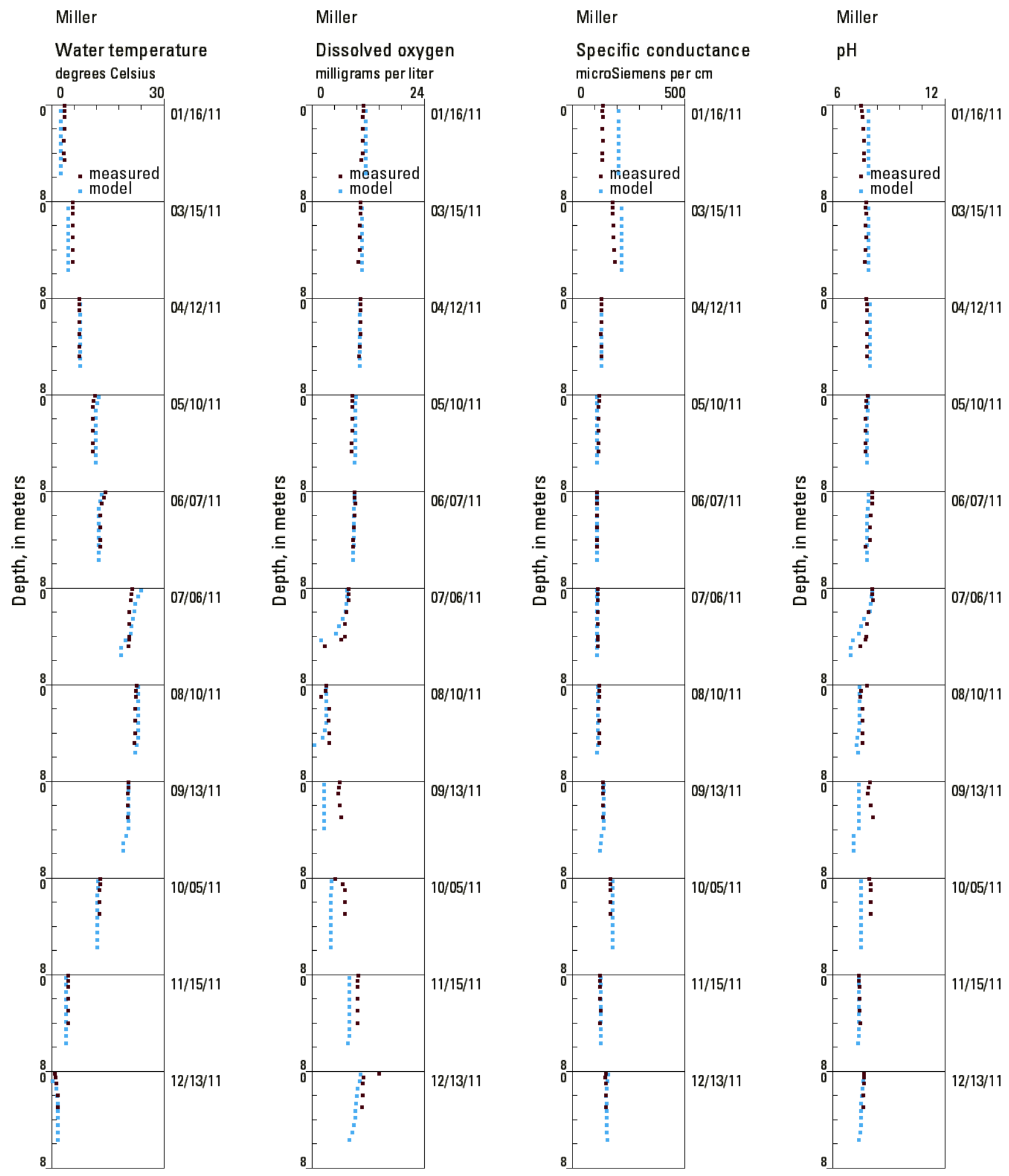

Figure 28. Graphs showing measured and modeled water temperature, dissolved oxygen, specific conductance, and pH profiles for calendar year 2011 for the Link-Keno reach of the Klamath River, Oregon. 

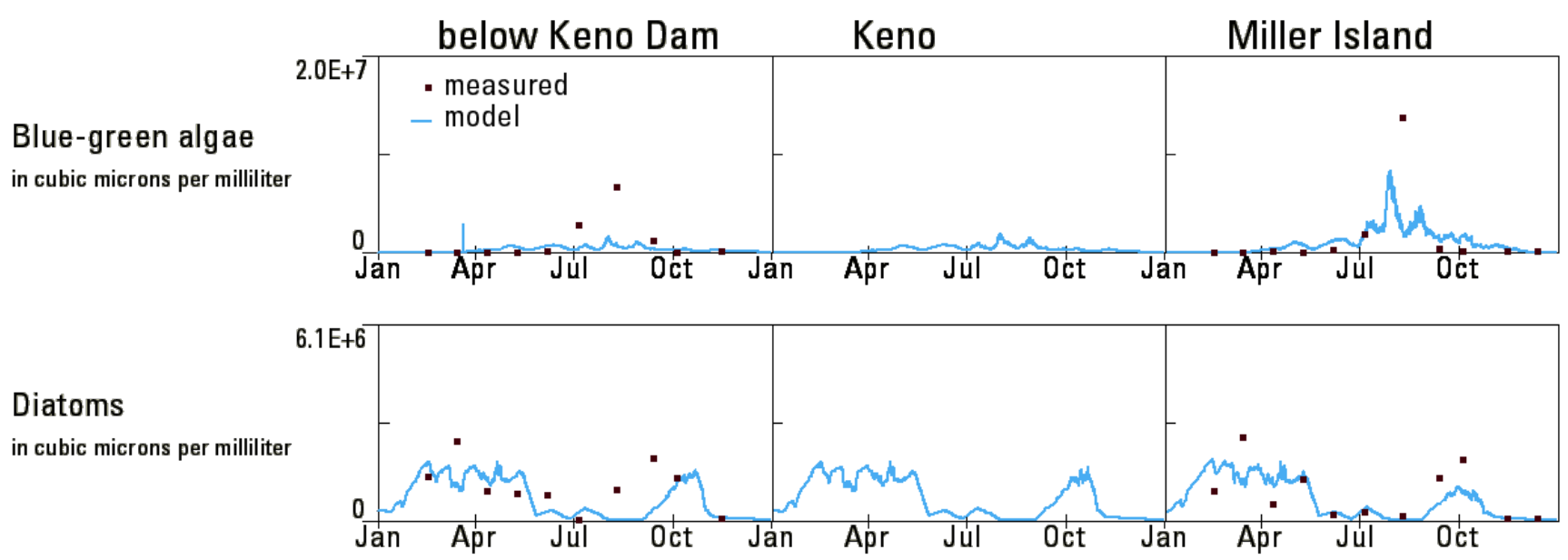

Other algae

in cubic microns per milliliter

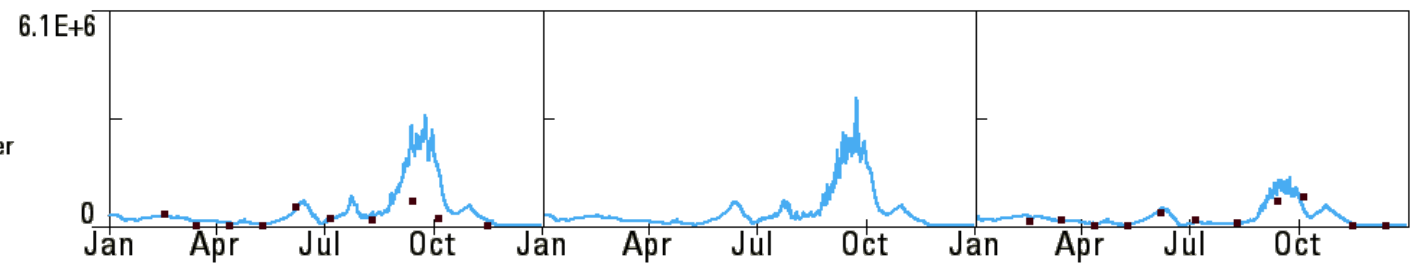

Chlorophyll a

in micrograms per liter

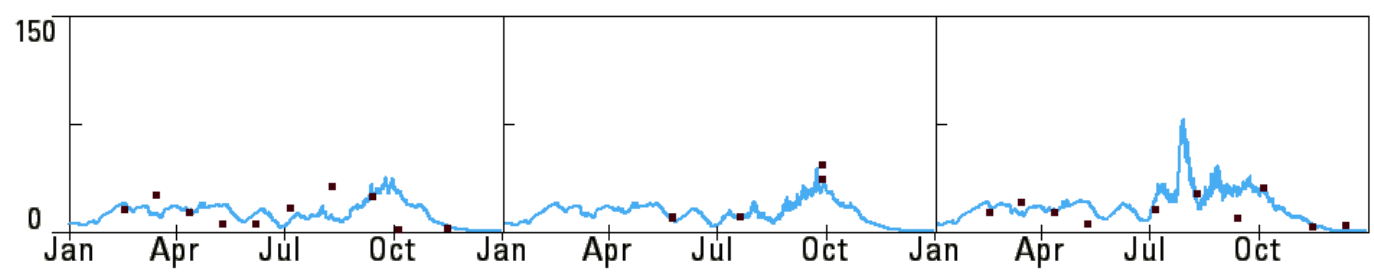

Total nitrogen

in milligrams per liter

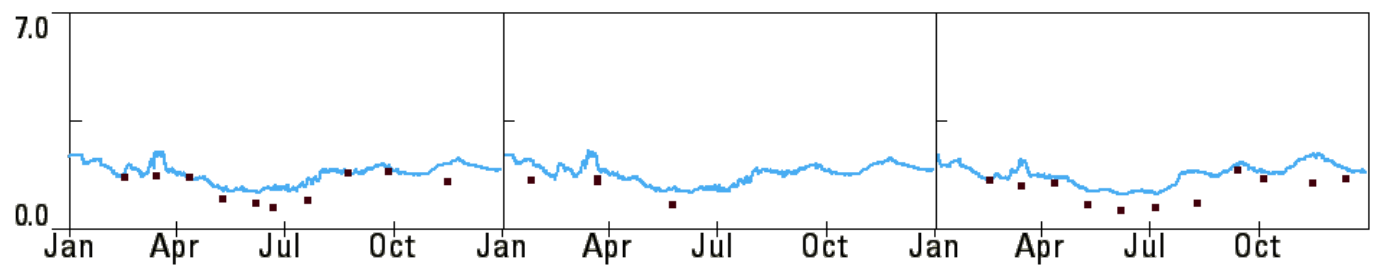

Particulate nitrogen

in milligrams per liter

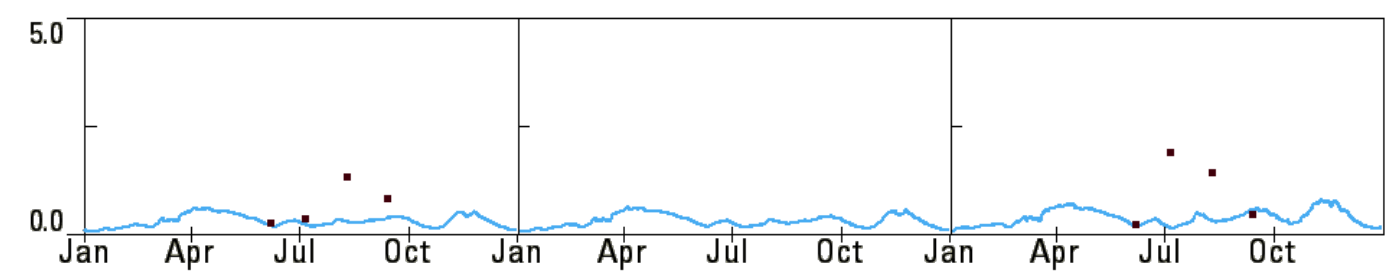

Nitrate+nitrite

in milligrams per liter

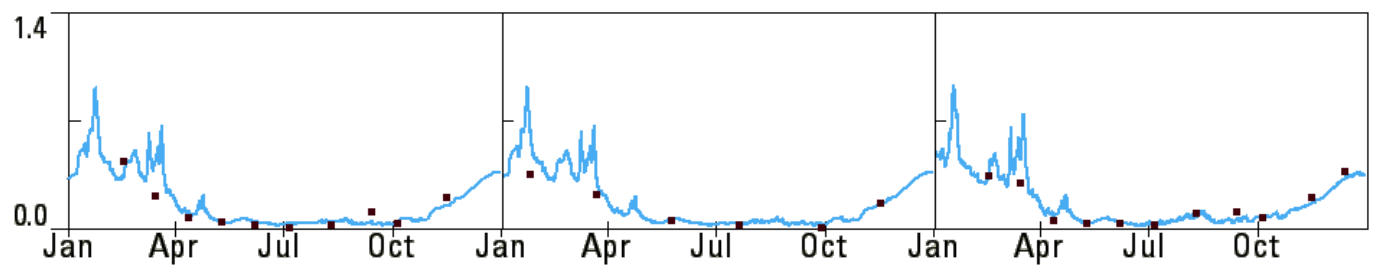

Figure 29. Graphs showing measured and modeled algae, nutrients, organic matter, and alkalinity for calendar year 2011 for sites in the Link-Keno reach of the Klamath River, Oregon. 


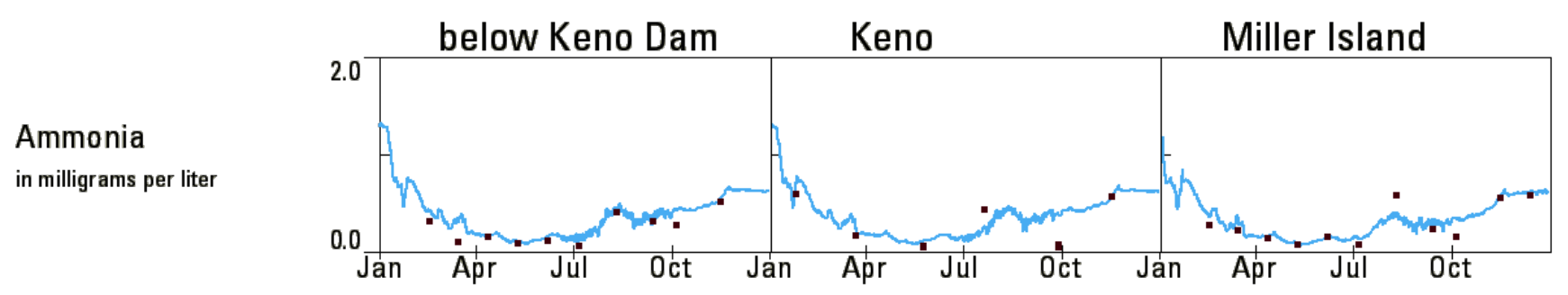

Total phosphorus

in milligrams per liter

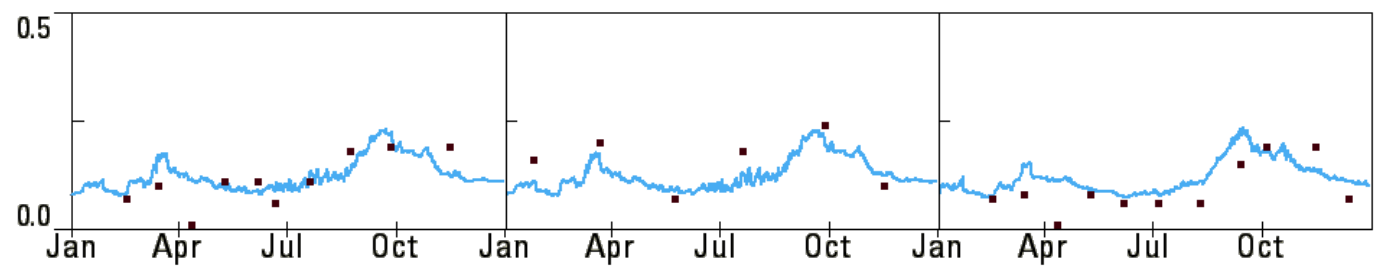

Orthophosphorus

in milligrams per liter

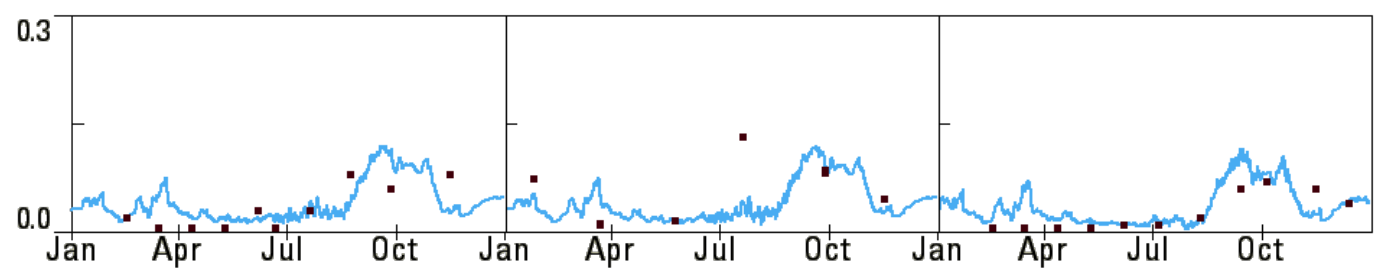

Particulate carbon

in milligrams per liter
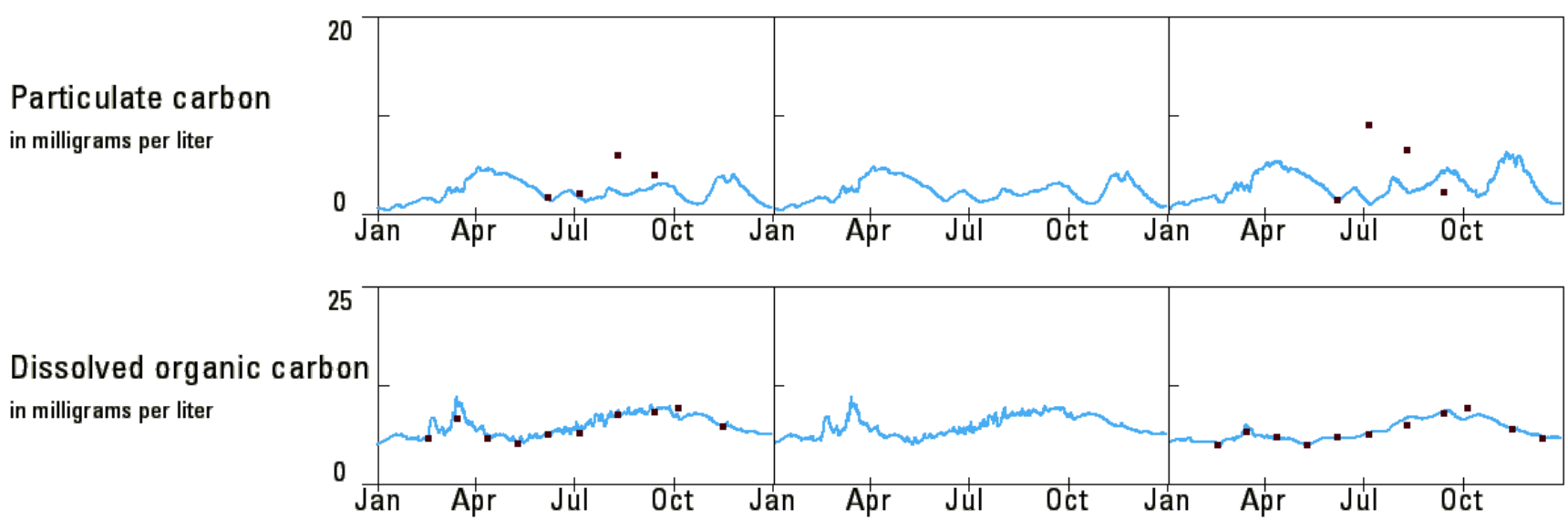

Alkalinity

in milligrams per liter

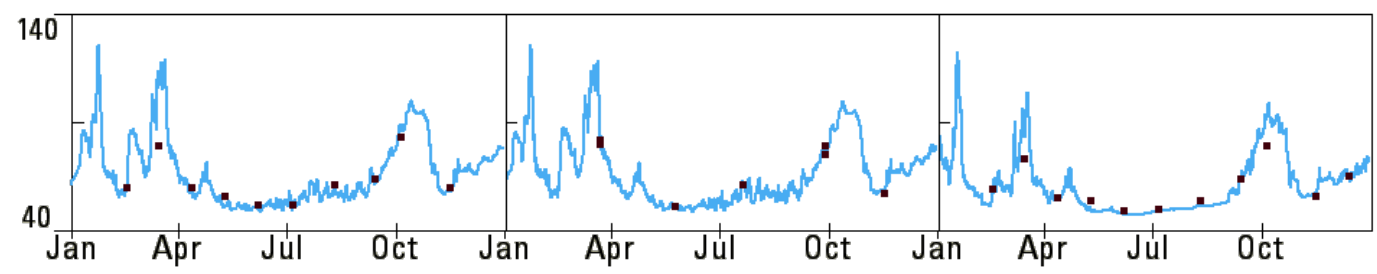

Bottom sediment

in milligrams per liter

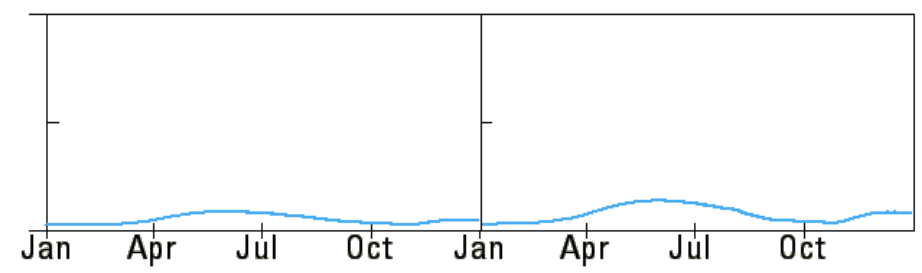

Figure 29-continued. Graphs showing measured and modeled algae, nutrients, organic matter, and alkalinity for calendar year 2011 for sites in the Link-Keno reach of the Klamath River, Oregon. 
Table 15. Goodness-of-fit statistics averaged over all calibration sites for the 2011 model test.

[Mean absolute error for the calibrated 2006-09 model is provided for comparison (Sullivan and others, 2013a). Abbreviations: ${ }^{\circ} \mathrm{C}$, degrees Celsius; mg/L, milligram per liter]

\begin{tabular}{|c|c|c|c|c|c|}
\hline Constituent & Unit & Data type & Mean error & \multicolumn{2}{|c|}{ Mean absolute error } \\
\hline & & & 2011 test & 2011 test & $\begin{array}{c}2006-09 \\
\text { calibrated }\end{array}$ \\
\hline Water temperature & ${ }^{\circ} \mathrm{C}$ & hourly & 0.04 & 0.69 & $0.55-0.63$ \\
\hline Dissolved oxygen & $\mathrm{mg} / \mathrm{L}$ & hourly & -0.83 & 1.44 & $0.95-1.27$ \\
\hline $\mathrm{pH}$ & & hourly & -0.12 & 0.33 & $0.25-0.34$ \\
\hline Ammonia & $\mathrm{mg} / \mathrm{L}$ & grab & 0.07 & 0.11 & $0.12-0.22$ \\
\hline Nitrate & $\mathrm{mg} / \mathrm{L}$ & grab & 0.05 & 0.07 & 0.03 \\
\hline Particulate nitrogen & $\mathrm{mg} / \mathrm{L}$ & grab & -0.70 & 0.75 & $0.25-0.29$ \\
\hline Total nitrogen & $\mathrm{mg} / \mathrm{L}$ & grab & 0.52 & 0.53 & $0.40-0.42$ \\
\hline Orthophosphorus & $\mathrm{mg} / \mathrm{L}$ & grab & 0.01 & 0.03 & $0.02-0.03$ \\
\hline Total phosphorus & $\mathrm{mg} / \mathrm{L}$ & grab & 0.01 & 0.04 & $0.04-0.05$ \\
\hline Particulate carbon & $\mathrm{mg} / \mathrm{L}$ & grab & -2.55 & 3.55 & $1.09-1.31$ \\
\hline $\begin{array}{l}\text { Dissolved organic } \\
\text { carbon }\end{array}$ & $\mathrm{mg} / \mathrm{L}$ & grab & 0.08 & 0.37 & $0.71-0.72$ \\
\hline
\end{tabular}

\section{Observations on 2011 Water Quality}

Running a model test on the atypical waterquality year of 2011 was an opportunity to examine the factors that may have contributed to improved conditions. A major driver of water quality in this reach, identified previously, is the inflowing Aphanizomenon flos-aquae from Upper Klamath Lake that, in part, settle and decay along the Link-Keno reach, pulling dissolved oxygen out of the water while releasing dissolved nutrients and dissolved organic and inorganic carbon. In 2011, several sources of measured algal and chlorophyll $a$ data indicated that less algae entered the Link-Keno reach from Upper Klamath Lake compared to previously modeled years (fig. 31). This is a likely a major contributor to water-quality improvement in 2011. Additionally, biovolumes of Anabaena flosaquae appear to have increased from Link Dam to Miller Island (fig. 30), suggesting that this algal species may have been growing, photosynthesizing, and producing dissolved oxygen in mid-summer in the Link-Keno reach. Finally, dissolved oxygen concentrations were high in late autumn 2011, when blue-green algal blooms were finished, so macrophyte photosynthesis would likely have been elevating dissolved oxygen concentrations at that time of year. All these processes, operating at different times throughout the summer and autumn, likely combined to produce improved dissolved oxygen conditions in 2011. 


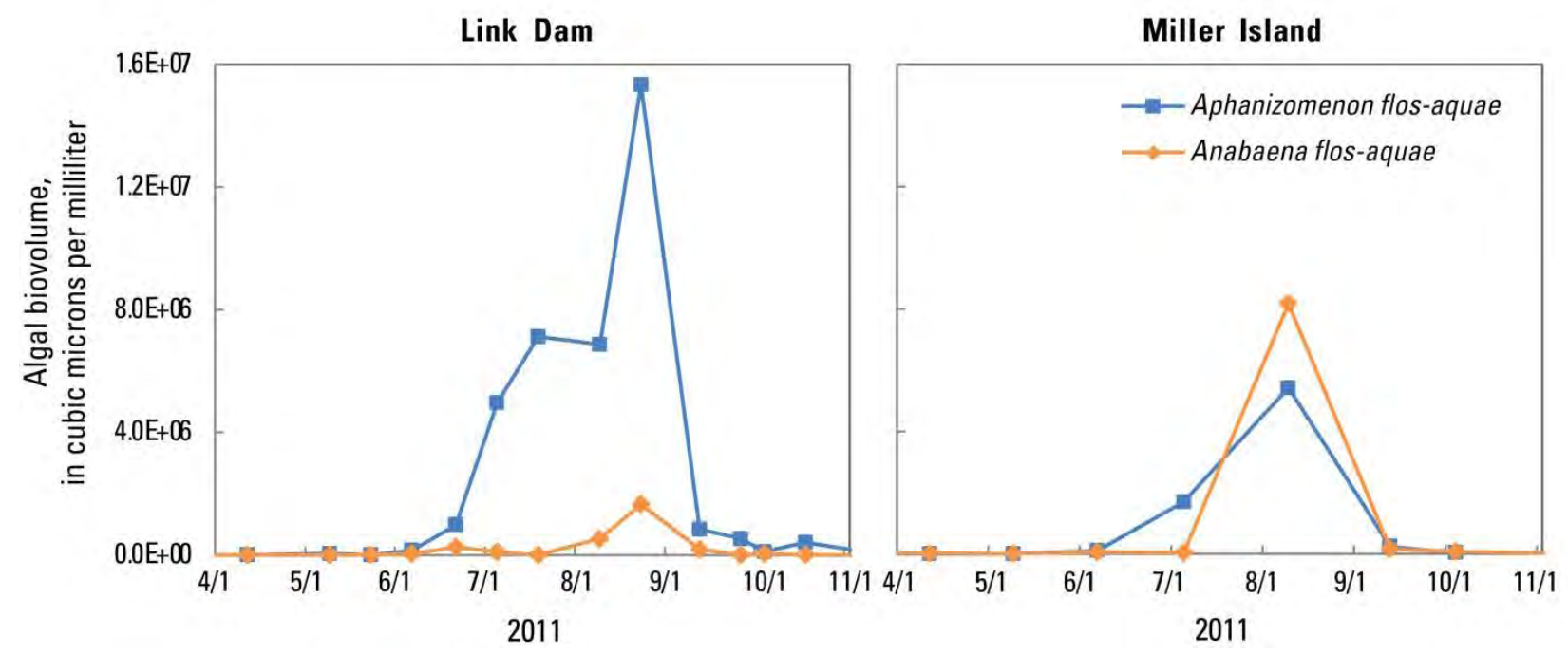

Figure 30. Graphs showing measured Aphanizomenon flos-aquae and Anabaena flos-aquae biovolume at Link Dam and Miller Island in April-October 2011. Data from Klamath Hydroelectric Settlement Agreement sampling as described in Watercourse Engineering, Inc., 2012.
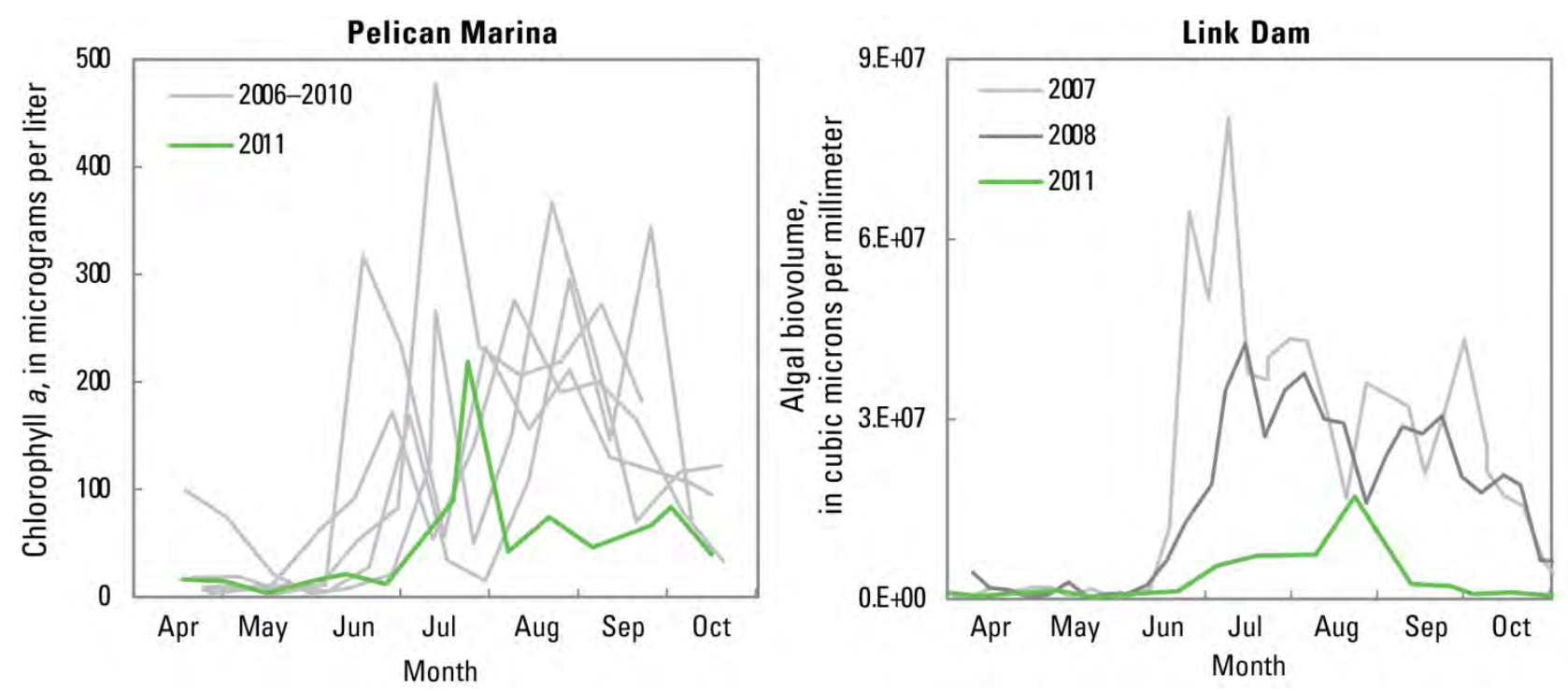

Figure 31. Graphs showing measured chlorophyll a concentrations at the southern end of Upper Klamath Lake (left) and algal biovolume at Link River for 2011 and prior years. Chlorophyll a data are from the Klamath Tribes and collected at Pelican Marina. Algal biovolume data were collected by the Bureau of Reclamation as part of U.S. Geological Survey and Klamath Hydroelectric Settlement Agreement (KHSA) projects (Sullivan and others 2008, 2009; Watercourse Engineering, Inc., 2012). Year 2007 and 2008 biovolume data were collected at the mouth of Link River, and year 2011 at the head of Link River just upstream of Link River Dam. 


\section{Acknowledgments}

Funding for this study was provided by Bureau of Reclamation. Rick Carlson provided helpful insights on Reclamation operations of the Klamath Project.

\section{Supplementary Material}

Calibrated Link-Keno models and associated material are available for download at http://or.water.usgs.gov/proj/keno_reach/.

\section{References Cited}

Brix, H., 1997, Do macrophytes play a role in constructed treatment wetlands?: Water Science and Technology, v. 35, p. 11-17.

Bureau of Reclamation, 2012, Klamath Project yield and water quality improvement options appraisal study - Summary, October 2012: Bureau of Reclamation, 141 p. plus appendix.

Burt, C., and Freeman, B., 2005, Recirculation in the Klamath Straits Drain and Lower Klamath National Wildlife Refuge, preliminary feasibility analysis. Irrigation Training and Research Center, October, 33 p.

Cahoon, J., 1985, Soil survey of Klamath County, Oregon, southern part: U.S. Soil Conservation Service, $269 \mathrm{p}$.

Carpenter, K.D., Snyder, D.T., Duff, J.H., Triska, F.J., Lee, K.K., Avanzino, R.J., and Sobieszczyk, S., 2009, Hydrologic and waterquality conditions during restoration of the Wood River Wetland, upper Klamath River basin, Oregon, 2003-05: U.S. Geological Survey Scientific Investigations Report 20095004, 66 p., http://pubs.usgs.gov/sir/2009/5004/.

CH2M-Hill, 2012, Approaches to water quality treatment by wetlands in the Upper Klamath Basin: Englewood, Colo., CH2M-Hill, prepared for PacifiCorp.

CH2M-Hill and Wells, S., 1995, Water quality model of the Klamath River between Link River and Keno Dam-Draft report for the
Oregon Department of Environmental Quality: Portland, Oregon [variously paged].

Cole, T.M., and Wells, S.A., 2008, CE-QUALW2-A two-dimensional, laterally averaged, hydrodynamic and water-quality model, version 3.6: U.S. Army Corps of Engineers, Instruction Report EL-08-1, [variously paged].

Coveney, M.F., Stites, D.L., Lowe, E.F., Battoe, L.E., and Conrow, R., 2002, Nutrient removal from eutrophic lake water by wetland filtration: Ecological Engineering, v. 19, p. 141-159.

Crites, R.W., 2006, Natural wastewater treatment systems: Boca Raton, Florida, CRC Press, 552 p.

Crites, R., and Tchobanoglous, G., 1998, Small and decentralized wastewater management systems: New York, WCB McGraw-Hill, p. 57-69, 563-643.

Danosky, E., and Kaffka, S., 2002, Farming practices and water quality in the upper Klamath Basin: Final Report to the California State Water Resources Control Board 205j Program, $168 \mathrm{p}$.

Deas, M., and Vaughn, J., 2006, Characterization of organic matter fate and transport in the Klamath River below Link Dam to assess treatment/reduction potential: Prepared for the Bureau of Reclamation Klamath Basin Area Office, September 30.

Deas, M.L., and Vaughn, J., 2011, Keno Reservoir particulate study 2008-Technical memorandum: Davis, California, Watercourse Engineering, Inc., Prepared for the Bureau of Reclamation, Klamath Basin Area Office, 38 p.

Deas, M., Vaughn, J., Limanto, E., Willis, A., Bale, A., and Rabe, A., 2012, Keno Reservoir wetlands feasibility study, Phase III-Organic matter removal using a treatment wetland in the Upper Klamath watershed-Pilot-scale treatment wetland pre-design assessment: Prepared for the Bureau of Reclamation, Klamath Basin Area Office, December 20. 
DePaoli, L.L., 1999, Numerical modelling of wetlands: Cambridge, Massachusetts Institute of Technology, Master's Thesis, 125 p.

Dileanis, P.D., Schwarzbach, S.E., Bennett, J., and others, 1996, Detailed study of water quality, bottom sediment and biota associated with irrigation drainage in the Klamath Basin, California and Oregon, 1990-92: U.S. Geological Survey Water-Resources Investigations Report 95-4232, 68 p., http://pubs.usgs.gov/wri/1995/4232/report.pdf.

Dunne, E.J., Reddy, R., and Clark, M.W., 2006, Biogeochemical indices of phosphorus retention and release by wetland soils and adjacent stream sediments: Wetlands, v. 26, p. 1,026-1,041.

Eagles-Smith, C.A., and Johnson, B.L., 2012, Contaminants in the Klamath Basin-Historical patterns, current distribution, and data gap identification: U.S. Geological Survey Administrative Report, 92 p., http://www.fws.gov/arcata/fisheries/reports/tec hnical/Eagles-

Smith\%20and\%20Johnson\%202012_Klamath \%20contaminants_Final_052312.pdf.

Jasper, J.T., and Sedlak, D.L., 2013,

Phototransformation of wastewater-derived trace organic contaminants in open-water unit process treatment wetlands: Environmental Science and Technology, 47, p. 10,781-90.

Kadlec, R.H., and Knight, R.L., 1996, Treatment wetlands: Boca Raton, Florida, Lewis Publishers, CRC Press.

Kadlec, R.H., and Wallace, S.D., 2009, Treatment wetlands (2nd ed.): Boca Raton, Florida, CRC Press, Boca Raton, 1,016 p.

Langevin, C.D., Swain, E.D., and Wolfert, M.A., 2002, Numerical simulation of integrated surface-water/groundwater flow and solute transport in the southern Everglades, Florida, Proceedings: Las Vegas, Nevada, Second Federal Interagency Hydrologic Modeling Conference, July 28-August 1, 2002.

Lin, Y., Jing, S., and Lee, D., 2003, The potential use of constructed wetlands in a recirculating aquaculture system for shrimp culture:

Environmental Pollution, v. 123, p. 107-113.

MacCoy, D.E., 1994, Physical, chemical, and biological data for detailed study of irrigation drainage in the Klamath Basin, California and Oregon, 1990-92: U.S. Geological Survey Open-File Report 93-497, 168 p., http://pubs.er.usgs.gov/publication/ofr93497.

Mahugh, S., Deas, M.L., Gearheart, R.A., Vaughn, J., Piaskowski, R., and Rabe, A., 2008, Keno Reservoir feasibility study, Phase IIIdentification and assessment of potential treatment wetland sites in the Upper Klamath River: Prepared for Bureau of Reclamation, Klamath Basin Area Office, Proposal No. 07SF200051, 49 p.

Mateos, L., Young, C.A., Wallender, W.W., and Carlson, H.L., 2000, Simulating spatially distributed water and salt balances: Journal of Irrigation and Drainage Engineering, v. 126, p. 288-295.

Mayer, T.D., 2005, Water-quality impacts of wetland management in the Lower Klamath National Wildlife Refuge, Oregon and California, USA: Wetlands, v. 25, p. 697-712.

Mitsch, W.J., and Gosselink, F.G., 2007, Wetlands (4th ed.): John Wiley and Sons, Inc. Hoboken, N.J., 582 p.

National Marine Fisheries Service and U.S. Fish and Wildlife Service, 2013, Effects of proposed Klamath Project operations from May 31, 2013, through March 31, 2023, on five federally listed threatened and endangered species: SWR-20129372, 08EKLA00-2013-F-0014, 590 p.

O’Brien, J.M., Hamilton, S.K., Kinsman-Costello, L.E., Lennon, J.T., and Ostrom, N.E., 2012, Nitrogen transformations in a through-flow wetland revealed using whole-ecosystem pulsed $15 \mathrm{~N}$ additions: Limnology and Oceanography, v. 57, p. 221-234.

Oregon Department of Environmental Quality, 2010, Upper Klamath and Lost River subbasins total maximum daily load (TMDL) and water quality management plan (WQMP): Oregon Department of Environmental Quality. 
Oregon Department of Environmental Quality, 2011, Oregon Administrative Rules OAR 340041: Oregon Department of Environmental Quality, accessed October 21, 2011, at http://arcweb.sos.state.or.us/pages/rules/oars_3 00/oar_340/340_041.html.

PacifiCorp, 2004, Klamath River modeling framework to support the PacifiCorp Federal Energy Regulatory Commission hydropower relicensing application, FERC Project No. 2082: Portland, Oregon..

PacifiCorp, 2005, Klamath River water quality model implementation, calibration, and validation, Klamath Hydroelectric Project, FERC Project No. 2082: Portland, Oregon.

Pauer, J.J., and Auer, M.T., 2009, Formulation and testing of a novel river nitrification model: Ecological Modelling, v. 220, p. 857-866.

Pinney, M.L., Westerhoff, P.K., and Baker. L, 2000, Transformations in dissolved organic carbon through constructed wetlands: Water Research, v. 34, p. 1,897-1,911.

Poindexter, C.M., and Variano, E.A., 2013, Gas exchange in wetlands with emergent vegetation-The effects of wind and thermal convection at the air-water interface: Journal of Geophysical Research Biogeosciences, v. 118, p.1,297-1,306.

Poulson, S.R., and Sullivan, A.B., 2010, Assessment of diel chemical and isotopic techniques to investigate biogeochemical cycles in the Upper Klamath River, Oregon, USA: Chemical Geology, v. 269, no. 1-2, p. 3-11.

Rhoades, J.D., Kandiah, A., and Mashali, A.M., 1992, The use of saline waters for crop production: Food and Agriculture Organization of the United Nations, Irrigation and Drainage paper 48.

Risley, J.C., and Gannett, M.W., 2006, An evaluation and review of water-use estimates and flow data for the Lower Klamath and Tule Lake National Wildlife Refuges, Oregon and California: U.S. Geological Survey Scientific Investigations Report 2006-5036, 18 p., http://pubs.usgs.gov/sir/2006/5036/.
Roig, L.C., 1995, Mathematical theory and numerical methods for modeling of wetland hydraulics, in Espey, Jr., W.H., Combs, P.G., eds., Water Resources EngineeringProceedings of the First International Conference: New York, American Society of Civil Engineers, v. 1, p. 249-253.

Robarts, R.D., and Waiser, M.J., 1998, Effects of atmospheric change and agriculture on the biogeochemistry and microbial ecology of prairie wetlands: Great Plains Research, v. 8, no. 1, p. 113-136.

Sorenson, S.K., and Schwarzbach, S.E., 1991, Reconnaissance investigation of water quality, bottom sediment, and biota associated with irrigation drainage in the Klamath Basin, California and Oregon, 1988-89: U.S. Geological Survey Water-Resources Investigations Report 90-4203, 64 p., http://pubs.er.usgs.gov/publication/wri904203.

Stannard, D.I., Gannett, M.W., Polette, D.J., Cameron, J.M., Waibel, M.S., and Spears, J.M., 2013, Evapotranspiration from marsh and openwater sites at Upper Klamath Lake, Oregon, 2008-2010: U.S. Geological Survey Scientific Investigations Report 2013-5014, 66 p.

Steensland, G., 2012, Lateral variability of water quality refugia created by near short aquatic macrophytes during periods of prolonged hypoxia in the Klamath River: Oregon Institute of Technology research paper, $28 \mathrm{p}$.

Stillwater Sciences, Jones and Trimiew Design, Atkins, Tetra Tech, Riverbend Sciences, Aquatic Ecosystem Sciences, and NSI/Biohabitats, 2013, Water quality improvement techniques for the Upper Klamath Basin-A technical workshop and project conceptual designs: Prepared for California State Coastal Conservancy, Oakland, California, 95 p., http://www.stillwatersci.com/resources/FINAL_ KLAMATH_WQ_IMPRV_TECHS_09_04_2013 .$p d f$

Sullivan, A.B., Deas, M.L., Asbill, J., Kirshtein, J.D., Butler, K., and Vaughn, J., 2009, Klamath 
River water quality data from Link River Dam to Keno Dam, Oregon, 2008: U.S. Geological Survey Open-File Report 2009-1105, 25 p., http://pubs.usgs.gov/of/2009/1105/.

Sullivan, A.B., Deas, M.L., Asbill, J., Kirshtein, J.D., Butler, K., Wellman, R.W., Stewart, M.A., and Vaughn, J., 2008, Klamath River Water quality and acoustic Doppler current profiler data from Link River Dam to Keno Dam, 2007: U.S. Geological Survey Open-File Report 2008-1185, 24 p., http://pubs.usgs.gov/of/2008/1185/.

Sullivan, A.B., Rounds, S.A., Asbill-Case, J.R., and Deas, M.L., 2013a, Macrophyte and pH buffering updates to the Klamath River waterquality model upstream of Keno Dam, Oregon: U.S. Geological Survey Scientific Investigations Report 2013-5016, 52 p., http://pubs.usgs.gov/sir/2013/5016/.

Sullivan, A.B., Rounds, S.R., Deas, M.L., Asbill, J.R., Wellman, R.E., Stewart, M.A., Johnston, M.W., and Sogutlugil, I.E., 2011, Modeling hydrodynamics, water temperature, and water quality in the Klamath River upstream of Keno Dam, Oregon, 2006-09: U.S. Geological Survey Scientific Investigations Report 2011-5105, 70 p., http://pubs.usgs.gov/sir/2011/5105/.

Sullivan, A.B., Snyder, D.M., and Rounds, S.A., 2010, Controls on biochemical oxygen demand in the upper Klamath River, Oregon: Chemical Geology, v. 269, no. 1-2, p. 12-21, http://or.water.usgs.gov/proj/keno_reach/downl oad/chemgeo_bod_final.pdf.

Sullivan, A.B., Sogutlugil, I.E., Rounds, S.A., and Deas, M.L., 2013b, Modeling the water-quality effects of changes to the Klamath River upstream of Keno Dam, Oregon: U.S. Geological Survey Scientific Investigations Report 2013-5135, 60 p., http://pubs.usgs.gov/sir/2013/5135/.

Tetra Tech, Inc., 2009, Model configuration and results, Klamath River model for TMDL development, Appendix 6: Prepared for: U.S. Environmental Protection Agency Region 9, U.S. Environmental Protection Agency Region
10, North Coast Regional Water Quality Control Board, and Oregon Department of Environmental Quality, 59 p.

Wagner, R.J., Boulger, R.W., Jr., Oblinger, C.J., and Smith, B.A., 2006, Guidelines and standard procedures for continuous water-quality monitors-Station operation, record computation, and data reporting: U.S. Geological Survey Techniques and Methods 1-D3, 51 p. plus 8 attachments, http://pubs.usgs.gov/tm/2006/tm1D3/.

Watercourse Engineering, Inc., 2012, Klamath River baseline water quality sampling, 2011 annual report, 79 p., data at http://www.kbmp.net/collaboration/klamathhydroelectric-settlement-agreement-monitoring.

Wetzel, R.G., Hatcher, P.G., and Bianchi, T.S., 1995, Natural photolysis by ultraviolet irradiance of recalcitrant dissolved organic matter to simple substrates for rapid bacterial metabolism: Limnology and Oceanography, v. 40, no. 8, p. 1,369-1,380.

Wetzel, R.G., 2001, Limnology (3rd ed.): San Francisco, California, Academic Press, 1,006 p.

Wong, S., and Hendrixson, H., 2011, Water quality conditions on the Williamson River delta, Oregon - Three years post-restoration: Klamath Falls, Oregon, Nature Conservancy, 2010 Annual Data Report, 38 p.

Wong, S., Barry, M., Rudd, N., Hendrixson, H., and Doehring, C., 2011, Nutrient release from a recently flooded delta wetland - Comparison of field measurements to laboratory results: Wetlands, v. 31, p. 433-443. 


\section{Appendix A-Recirculation Scenario Results}

Table A1. Modeled monthly median water quality in the Ady Canal under base case conditions and for the recirculation scenario for calendar years 2006-09.

\begin{tabular}{|c|c|c|c|c|c|c|c|c|c|c|c|c|c|c|c|c|c|c|c|c|c|c|c|c|}
\hline & \multicolumn{8}{|c|}{ Specific conductance $(\mu \mathrm{S} / \mathrm{cm})$} & \multicolumn{8}{|c|}{ Inorganic suspended sediment, $\mathrm{mg} / \mathrm{L}$} & \multicolumn{8}{|c|}{ Water temperature, $\mathrm{C}$} \\
\hline & \multicolumn{4}{|c|}{ base case } & \multicolumn{4}{|c|}{ recirculation } & \multicolumn{4}{|c|}{ base case } & \multicolumn{4}{|c|}{ recirculation } & \multicolumn{4}{|c|}{ base case } & \multicolumn{4}{|c|}{ recirculation } \\
\hline & 06 & 07 & 08 & 09 & 06 & 07 & 08 & 09 & 06 & 07 & 08 & 09 & 06 & 07 & 08 & 09 & 06 & 07 & 08 & 09 & 06 & 07 & 08 & 09 \\
\hline Jan & 148 & 158 & 161 & 161 & 664 & 336 & 320 & 268 & 6.2 & 2.3 & 4.5 & 2.0 & 72.6 & 7.9 & 21.8 & 3.5 & 0.9 & 1.6 & 1.9 & 1.8 & 1.0 & 1.2 & 1.1 & 1.8 \\
\hline Feb & 151 & 170 & 177 & 154 & 817 & 417 & 516 & 420 & 11.0 & 2.6 & 4.9 & 2.4 & 151.7 & 15.9 & 37.4 & 78.8 & 3.1 & 3.7 & 3.0 & 3.3 & 3.9 & 3.7 & 1.3 & 4.2 \\
\hline Mar & 165 & 143 & 265 & 191 & 772 & 626 & 552 & 445 & 20.6 & 7.0 & 52.9 & 17.7 & 162.2 & 119.2 & 90.1 & 312.4 & 3.6 & 8.6 & 5.7 & 4.6 & 4.4 & 10.0 & 5.0 & 4.8 \\
\hline Apr & 188 & 107 & 138 & 133 & 825 & 688 & 759 & 728 & 12.8 & 3.8 & 5.0 & 10.1 & 153.9 & 12.0 & 53.2 & 46.5 & 7.5 & 13.3 & 8.3 & 8.8 & 8.5 & 15.7 & 10.3 & 10.3 \\
\hline May & 110 & 110 & 138 & 120 & 814 & 486 & 586 & 539 & 4.4 & 3.5 & 3.6 & 4.6 & 22.1 & 4.6 & 5.0 & 5.0 & 15.3 & 17.9 & 14.5 & 17.6 & 16.7 & 18.5 & 15.0 & 18.9 \\
\hline Jun & 107 & 112 & 114 & 122 & 441 & 310 & 478 & 471 & 4.3 & 3.8 & 3.8 & 3.5 & 4.9 & 4.4 & 4.8 & 4.8 & 19.5 & 20.9 & 18.9 & 19.5 & 21.0 & 21.1 & 20.0 & 19.8 \\
\hline Jul & 113 & 119 & 117 & 122 & 235 & 232 & 204 & 248 & 3.3 & 3.3 & 3.3 & 3.4 & 4.2 & 4.2 & 4.1 & 4.4 & 24.4 & 24.4 & 23.6 & 23.3 & 24.6 & 24.6 & 23.6 & 23.9 \\
\hline Aug & 117 & 112 & 125 & 128 & 257 & 187 & 170 & 190 & 3.0 & 3.1 & 3.2 & 3.2 & 4.4 & 4.0 & 3.9 & 3.9 & 21.6 & 22.2 & 22.3 & 21.1 & 21.7 & 22.2 & 22.3 & 21.3 \\
\hline Sep & 161 & 143 & 145 & 123 & 226 & 196 & 186 & 196 & 3.2 & 2.9 & 3.2 & 3.2 & 4.0 & 3.5 & 3.8 & 4.0 & 17.0 & 18.3 & 18.1 & 18.5 & 16.6 & 18.0 & 18.0 & 18.5 \\
\hline Oct & 183 & 174 & 139 & 145 & 222 & 233 & 190 & 214 & 3.4 & 3.0 & 3.3 & 3.3 & 3.7 & 3.7 & 3.7 & 3.9 & 11.0 & 8.6 & 9.8 & 9.9 & 11.0 & 9.0 & 9.8 & 10.1 \\
\hline Nov & 157 & 152 & 136 & 135 & 196 & 200 & 209 & 241 & 3.3 & 4.7 & 3.3 & 9.4 & 4.1 & 7.3 & 4.1 & 9.9 & 4.6 & 6.7 & 5.5 & 2.5 & 4.9 & 6.8 & 5.5 & 2.7 \\
\hline Dec & 178 & 145 & 146 & 148 & 299 & 201 & 203 & 242 & 3.2 & 19.1 & 3.4 & 15.9 & 5.8 & 19.9 & 3.9 & 16.6 & 1.4 & 1.3 & 1.0 & 1.1 & 1.4 & 1.2 & 0.9 & 0.9 \\
\hline
\end{tabular}

\begin{tabular}{|c|c|c|c|c|c|c|c|c|c|c|c|c|c|c|c|c|c|c|c|c|c|c|c|c|}
\hline & \multicolumn{8}{|c|}{ Dissolved oxygen, $\mathrm{mg} / \mathrm{L}$} & \multicolumn{8}{|c|}{ Ortho-phosphorus, mg/L } & \multicolumn{8}{|c|}{ Ammonia, $\mathrm{mg} / \mathrm{L}$} \\
\hline & \multicolumn{4}{|c|}{ base case } & \multicolumn{4}{|c|}{ recirculation } & \multicolumn{4}{|c|}{ base case } & \multicolumn{4}{|c|}{ recirculation } & \multicolumn{4}{|c|}{ base case } & \multicolumn{4}{|c|}{ recirculation } \\
\hline & 06 & 07 & 08 & 09 & 06 & 07 & 08 & 09 & 06 & 07 & 08 & 09 & 06 & 07 & 08 & 09 & 06 & 07 & 08 & 09 & 06 & 07 & 08 & 09 \\
\hline Jan & 12.3 & 10.4 & 9.4 & 10.2 & 11.5 & 10.4 & 8.8 & 9.9 & 0.05 & 0.05 & 0.05 & 0.06 & 0.20 & 0.09 & 0.09 & 0.06 & 0.61 & 0.89 & 0.95 & 1.24 & 0.43 & 0.82 & 0.82 & 1.12 \\
\hline Feb & 12.1 & 10.1 & 8.9 & 10.9 & 12.3 & 8.8 & 7.0 & 9.9 & 0.05 & 0.05 & 0.06 & 0.05 & 0.39 & 0.15 & 0.13 & 0.09 & 0.29 & 0.67 & 1.08 & 0.81 & 0.26 & 0.59 & 0.55 & 0.47 \\
\hline Mar & 11.3 & 10.0 & 9.2 & 10.4 & 11.3 & 7.5 & 6.0 & 8.6 & 0.05 & 0.03 & 0.11 & 0.08 & 0.48 & 0.22 & 0.14 & 0.14 & 0.10 & 0.36 & 0.78 & 0.64 & 0.20 & 0.39 & 0.38 & 0.38 \\
\hline Apr & 9.8 & 9.4 & 10.2 & 9.5 & 8.7 & 8.5 & 8.6 & 8.4 & 0.07 & 0.02 & 0.02 & 0.03 & 0.46 & 0.22 & 0.14 & 0.23 & 0.11 & 0.10 & 0.06 & 0.11 & 0.35 & 0.50 & 0.24 & 0.26 \\
\hline May & 8.5 & 8.5 & 8.8 & 8.1 & 6.9 & 6.2 & 7.1 & 5.4 & 0.03 & 0.04 & 0.04 & 0.03 & 0.41 & 0.24 & 0.22 & 0.32 & 0.07 & 0.10 & 0.11 & 0.13 & 0.58 & 0.38 & 0.28 & 0.28 \\
\hline Jun & 8.5 & 9.1 & 8.1 & 7.1 & 5.8 & 6.4 & 6.6 & 4.8 & 0.05 & 0.06 & 0.03 & 0.06 & 0.33 & 0.15 & 0.19 & 0.28 & 0.10 & 0.14 & 0.11 & 0.23 & 0.69 & 0.28 & 0.19 & 0.35 \\
\hline Jul & 3.0 & 1.5 & 1.6 & 1.2 & 2.9 & 2.2 & 2.7 & 1.9 & 0.11 & 0.16 & 0.07 & 0.09 & 0.20 & 0.20 & 0.17 & 0.18 & 0.57 & 1.07 & 0.69 & 0.56 & 0.62 & 0.59 & 0.63 & 0.49 \\
\hline Aug & 3.0 & 1.4 & 0.6 & 0.8 & 3.0 & 1.7 & 1.5 & 1.4 & 0.11 & 0.15 & 0.12 & 0.10 & 0.19 & 0.23 & 0.16 & 0.14 & 0.59 & 0.84 & 0.75 & 0.62 & 0.45 & 0.79 & 0.70 & 0.55 \\
\hline Sep & 2.7 & 2.0 & 1.0 & 0.7 & 2.9 & 2.4 & 1.9 & 1.6 & 0.12 & 0.15 & 0.11 & 0.08 & 0.15 & 0.18 & 0.15 & 0.12 & 0.68 & 0.74 & 0.56 & 0.61 & 0.42 & 0.78 & 0.58 & 0.51 \\
\hline Oct & 2.7 & 5.5 & 1.8 & 1.9 & 3.5 & 6.3 & 3.3 & 3.1 & 0.12 & 0.10 & 0.11 & 0.08 & 0.12 & 0.10 & 0.11 & 0.10 & 0.61 & 0.45 & 0.49 & 0.57 & 0.49 & 0.47 & 0.51 & 0.49 \\
\hline Nov & 7.7 & 7.0 & 6.1 & 9.1 & 8.7 & 7.6 & 7.2 & 9.3 & 0.09 & 0.06 & 0.08 & 0.03 & 0.09 & 0.06 & 0.08 & 0.05 & 0.70 & 0.69 & 1.19 & 0.80 & 0.61 & 0.63 & 1.05 & 0.68 \\
\hline Dec & 9.4 & 10.3 & 9.7 & 9.9 & 10.1 & 10.3 & 9.7 & 9.8 & 0.09 & 0.04 & 0.06 & 0.03 & 0.08 & 0.05 & 0.05 & 0.05 & 0.77 & 0.97 & 1.23 & 0.74 & 0.71 & 0.95 & 1.23 & 0.64 \\
\hline
\end{tabular}




\begin{tabular}{|c|c|c|c|c|c|c|c|c|c|c|c|c|c|c|c|c|c|c|c|c|c|c|c|c|}
\hline & \multicolumn{8}{|c|}{ Nitrate, mg/L } & \multicolumn{8}{|c|}{ Dissolved organic carbon, $\mathrm{mg} / \mathrm{L}$} & \multicolumn{8}{|c|}{ Particulate organic carbon, $\mathrm{mg} / \mathrm{L}$} \\
\hline & \multicolumn{4}{|c|}{ base case } & \multicolumn{4}{|c|}{ recirculation } & \multicolumn{4}{|c|}{ base case } & \multicolumn{4}{|c|}{ recirculation } & \multicolumn{4}{|c|}{ base case } & \multicolumn{4}{|c|}{ recirculation } \\
\hline & 06 & 07 & 08 & 09 & 06 & 07 & 08 & 09 & 06 & 07 & 08 & 09 & 06 & 07 & 08 & 09 & 06 & 07 & 08 & 09 & 06 & 07 & 08 & 09 \\
\hline Jan & 0.32 & 0.36 & 0.45 & 0.39 & 0.42 & 0.76 & 0.62 & 0.52 & 5.4 & 5.2 & 5.2 & 5.2 & 14.6 & 9.2 & 9.4 & 8.3 & 0.5 & 0.4 & 0.3 & 0.5 & 1.9 & 1.0 & 0.9 & 0.9 \\
\hline Feb & 0.24 & 0.38 & 0.43 & 0.26 & 0.36 & 0.70 & 0.60 & 0.52 & 5.9 & 5.4 & 5.6 & 5.3 & 18.7 & 13.2 & 13.9 & 17.5 & 0.5 & 0.4 & 0.5 & 0.5 & 3.2 & 1.7 & 1.8 & 2.9 \\
\hline Mar & 0.21 & 0.31 & 0.50 & 0.31 & 0.33 & 0.35 & 0.53 & 0.43 & 6.3 & 5.3 & 7.6 & 6.4 & 21.3 & 19.7 & 19.8 & 19.9 & 0.5 & 0.8 & 1.3 & 0.6 & 4.1 & 4.3 & 4.8 & 3.6 \\
\hline Apr & 0.20 & 0.24 & 0.04 & 0.05 & 0.27 & 0.18 & 0.21 & 0.18 & 6.4 & 6.3 & 5.8 & 6.0 & 27.1 & 24.4 & 24.4 & 23.9 & 0.7 & 0.8 & 1.4 & 0.8 & 5.3 & 2.3 & 7.1 & 4.8 \\
\hline May & 0.03 & 0.07 & 0.07 & 0.03 & 0.19 & 0.12 & 0.11 & 0.10 & 6.6 & 6.6 & 6.8 & 5.8 & 25.5 & 22.4 & 22.1 & 22.7 & 0.5 & 0.8 & 1.0 & 1.1 & 4.4 & 1.4 & 3.2 & 3.9 \\
\hline Jun & 0.03 & 0.05 & 0.04 & 0.07 & 0.11 & 0.08 & 0.07 & 0.08 & 6.9 & 7.0 & 6.6 & 6.1 & 18.7 & 15.8 & 17.4 & 18.4 & 0.7 & 1.0 & 1.2 & 1.7 & 2.4 & 0.9 & 1.6 & 2.5 \\
\hline Jul & 0.04 & 0.03 & 0.02 & 0.03 & 0.07 & 0.05 & 0.05 & 0.05 & 10.1 & 9.4 & 8.9 & 8.0 & 13.9 & 14.4 & 12.5 & 13.7 & 2.1 & 3.6 & 3.6 & 4.6 & 1.9 & 2.8 & 2.8 & 2.9 \\
\hline Aug & 0.04 & 0.03 & 0.00 & 0.01 & 0.10 & 0.06 & 0.04 & 0.03 & 11.2 & 12.2 & 10.5 & 8.1 & 15.0 & 15.1 & 13.4 & 11.5 & 1.8 & 2.5 & 4.8 & 4.4 & 1.9 & 2.3 & 3.6 & 3.4 \\
\hline Sep & 0.04 & 0.04 & 0.01 & 0.01 & 0.08 & 0.07 & 0.09 & 0.05 & 11.2 & 12.5 & 10.6 & 8.0 & 13.4 & 14.3 & 13.3 & 11.7 & 2.0 & 1.9 & 2.2 & 3.8 & 1.8 & 1.7 & 1.9 & 2.9 \\
\hline Oct & 0.11 & 0.13 & 0.07 & 0.10 & 0.12 & 0.21 & 0.18 & 0.12 & 10.9 & 10.5 & 10.0 & 7.9 & 11.6 & 11.6 & 11.1 & 9.8 & 1.3 & 1.1 & 1.9 & 3.1 & 1.4 & 1.2 & 1.9 & 2.8 \\
\hline Nov & 0.27 & 0.30 & 0.20 & 0.33 & 0.28 & 0.35 & 0.27 & 0.33 & 8.4 & 8.0 & 8.9 & 7.6 & 9.5 & 9.2 & 10.1 & 9.1 & 0.7 & 0.3 & 1.1 & 0.9 & 1.0 & 0.8 & 1.4 & 1.3 \\
\hline Dec & 0.42 & 0.38 & 0.38 & 0.31 & 0.57 & 0.46 & 0.48 & 0.38 & 6.6 & 6.1 & 6.1 & 6.2 & 7.7 & 7.1 & 8.1 & 8.2 & 0.4 & 0.2 & 0.5 & 0.4 & 0.7 & 0.4 & 0.7 & 0.8 \\
\hline
\end{tabular}

\begin{tabular}{|c|c|c|c|c|c|c|c|c|c|c|c|c|c|c|c|c|}
\hline & \multicolumn{8}{|c|}{ Algae, in $\mathrm{mg} / \mathrm{L}$} & \multicolumn{8}{|c|}{$\mathrm{pH}$, in standard units } \\
\hline & \multicolumn{4}{|c|}{ base case } & \multicolumn{4}{|c|}{ recirculation } & \multicolumn{4}{|c|}{ base case } & \multicolumn{4}{|c|}{ recirculation } \\
\hline & 06 & 07 & 08 & 09 & 06 & 07 & 08 & 09 & 06 & 07 & 08 & 09 & 06 & 07 & 08 & 09 \\
\hline Jan & 0.07 & 0.06 & 0.13 & 0.07 & 0.06 & 0.06 & 0.09 & 0.07 & 7.8 & 7.6 & 7.5 & 7.7 & 7.8 & 7.4 & 7.3 & 7.6 \\
\hline Feb & 0.07 & 0.06 & 0.16 & 0.07 & 0.06 & 0.06 & 0.06 & 0.06 & 9.1 & 7.9 & 7.5 & 8.1 & 8.5 & 7.5 & 7.2 & 7.7 \\
\hline Mar & 0.14 & 0.07 & 0.13 & 0.07 & 0.08 & 0.06 & 0.06 & 0.06 & 8.3 & 7.9 & 7.6 & 8.2 & 8.4 & 7.6 & 7.2 & 7.7 \\
\hline Apr & 0.95 & 0.30 & 1.00 & 0.60 & 1.13 & 0.85 & 1.35 & 1.01 & 8.0 & 8.0 & 8.3 & 8.1 & 8.2 & 8.2 & 8.1 & 8.1 \\
\hline May & 0.71 & 0.38 & 0.30 & 0.48 & 0.49 & 0.41 & 0.28 & 0.73 & 7.9 & 8.3 & 8.3 & 8.0 & 8.7 & 8.0 & 8.3 & 7.9 \\
\hline Jun & 1.12 & 0.26 & 0.57 & 0.84 & 0.73 & 0.49 & 0.59 & 0.68 & 8.2 & 8.7 & 8.5 & 8.8 & 8.4 & 7.8 & 8.7 & 8.3 \\
\hline Jul & 1.20 & 1.73 & 1.17 & 0.54 & 0.90 & 0.93 & 0.92 & 0.55 & 8.8 & 7.9 & 9.1 & 7.7 & 8.0 & 7.9 & 8.4 & 7.6 \\
\hline Aug & 0.74 & 0.88 & 0.69 & 0.65 & 0.62 & 0.74 & 0.54 & 0.60 & 7.6 & 7.5 & 7.8 & 7.8 & 7.9 & 7.3 & 7.5 & 7.5 \\
\hline Sep & 1.11 & 0.74 & 0.84 & 0.57 & 0.86 & 0.65 & 0.57 & 0.44 & 8.3 & 7.3 & 7.4 & 8.0 & 7.9 & 7.4 & 7.3 & 7.5 \\
\hline Oct & 1.35 & 0.75 & 1.09 & 0.46 & 1.18 & 0.70 & 0.97 & 0.45 & 7.6 & 7.5 & 7.4 & 7.2 & 7.6 & 7.7 & 7.5 & 7.3 \\
\hline Nov & 0.49 & 0.13 & 0.23 & 0.07 & 0.49 & 0.14 & 0.22 & 0.08 & 7.4 & 7.5 & 7.4 & 7.6 & 7.7 & 7.6 & 7.6 & 7.8 \\
\hline Dec & 0.11 & 0.07 & 0.09 & 0.07 & 0.08 & 0.07 & 0.08 & 0.06 & 7.7 & 7.6 & 7.7 & 7.6 & 7.7 & 7.7 & 7.7 & 7.5 \\
\hline
\end{tabular}


Table A2. Modeled monthly volume-average concentrations and temperature in the Klamath River between the Klamath Straits Drain outflow and Keno Dam in the base case and in the recirculation scenario for calendar years 2006-09.

\begin{tabular}{|c|c|c|c|c|c|c|c|c|c|c|c|c|c|c|c|c|c|c|c|c|c|c|c|c|}
\hline & \multicolumn{8}{|c|}{ Specific conductance $(\mu \mathrm{S} / \mathrm{cm})$} & \multicolumn{8}{|c|}{ Inorganic suspended sediment, $\mathrm{mg} / \mathrm{L}$} & \multicolumn{8}{|c|}{ Water temperature, $\mathrm{C}$} \\
\hline & \multicolumn{4}{|c|}{ base case } & \multicolumn{4}{|c|}{ recirculation } & \multicolumn{4}{|c|}{ base case } & \multicolumn{4}{|c|}{ recirculation } & \multicolumn{4}{|c|}{ base case } & \multicolumn{4}{|c|}{ recirculation } \\
\hline & 06 & 07 & 08 & 09 & 06 & 07 & 08 & 09 & 06 & 07 & 08 & 09 & 06 & 07 & 08 & 09 & 06 & 07 & 08 & 09 & 06 & 07 & 08 & 09 \\
\hline Jan & 196 & 199 & 197 & 186 & 184 & 165 & 162 & 158 & 10.7 & 3.3 & 8.1 & 2.4 & 9.1 & 2.4 & 5.3 & 2.1 & 1.0 & 1.3 & 1.7 & 1.7 & 1.0 & 1.4 & 1.9 & 1.7 \\
\hline Feb & 238 & 222 & 243 & 210 & 228 & 187 & 210 & 172 & 23.1 & 7.1 & 12.4 & 27.9 & 20.5 & 3.6 & 8.9 & 13.8 & 2.9 & 3.6 & 2.8 & 3.2 & 2.9 & 3.6 & 2.9 & 3.1 \\
\hline Mar & 251 & 191 & 339 & 274 & 230 & 172 & 329 & 268 & 37.6 & 24.2 & 73.5 & 75.8 & 33.2 & 16.7 & 71.8 & 71.9 & 3.8 & 8.0 & 5.9 & 5.8 & 3.8 & 7.9 & 5.9 & 5.7 \\
\hline Apr & 214 & 171 & 190 & 214 & 212 & 164 & 177 & 194 & 15.2 & 5.2 & 9.5 & 16.1 & 15.2 & 5.1 & 8.2 & 15.8 & 9.5 & 11.2 & 8.9 & 10.2 & 9.5 & 11.2 & 8.8 & 10.2 \\
\hline May & 170 & 165 & 196 & 178 & 151 & 114 & 157 & 151 & 5.6 & 3.3 & 4.6 & 4.9 & 5.0 & 3.2 & 4.0 & 5.0 & 16.1 & 17.5 & 15.1 & 15.9 & 16.1 & 17.4 & 15.0 & 15.9 \\
\hline Jun & 135 & 148 & 197 & 177 & 116 & 113 & 157 & 139 & 4.4 & 3.6 & 3.6 & 3.4 & 4.3 & 3.5 & 3.5 & 3.2 & 20.2 & 20.6 & 18.5 & 19.8 & 20.1 & 20.6 & 18.4 & 19.7 \\
\hline Jul & 136 & 145 & 142 & 145 & 113 & 120 & 119 & 123 & 3.3 & 3.1 & 3.2 & 3.2 & 3.2 & 3.0 & 3.1 & 3.1 & 24.4 & 24.2 & 23.8 & 23.4 & 24.4 & 24.2 & 23.8 & 23.4 \\
\hline Aug & 151 & 130 & 139 & 141 & 117 & 113 & 126 & 128 & 2.8 & 2.9 & 3.0 & 3.0 & 2.6 & 2.7 & 2.8 & 2.8 & 21.7 & 22.6 & 22.3 & 21.5 & 21.7 & 22.6 & 22.3 & 21.5 \\
\hline Sep & 170 & 157 & 148 & 141 & 154 & 145 & 136 & 123 & 2.9 & 2.7 & 2.9 & 2.9 & 2.7 & 2.6 & 2.8 & 2.7 & $\begin{array}{ll}17.1 \\
\end{array}$ & 17.4 & 18.0 & 18.4 & 17.1 & 17.4 & 18.0 & 18.4 \\
\hline Oct & 186 & 183 & 154 & 155 & 177 & 175 & 145 & 148 & 3.0 & 2.8 & 3.0 & 5.4 & 3.0 & 2.7 & 3.0 & 4.8 & 11.3 & 8.9 & 10.8 & 9.8 & 11.3 & 8.9 & 10.8 & 9.8 \\
\hline Nov & 168 & 159 & 161 & 146 & 159 & 152 & 152 & 138 & 3.1 & 5.0 & 3.1 & 11.9 & 3.0 & 4.7 & 3.0 & 12.0 & 4.6 & 5.7 & 5.7 & 3.8 & 4.6 & 5.7 & 5.6 & 3.8 \\
\hline Dec & 204 & 159 & 162 & 162 & 190 & 145 & 154 & 148 & 3.4 & 19.3 & 3.2 & 15.3 & 3.0 & 18.9 & 3.1 & 15.4 & 1.3 & 1.1 & 1.5 & 1.0 & 1.3 & 1.0 & 1.5 & 1.0 \\
\hline
\end{tabular}

\begin{tabular}{|c|c|c|c|c|c|c|c|c|c|c|c|c|c|c|c|c|c|c|c|c|c|c|c|c|}
\hline & \multicolumn{8}{|c|}{ Dissolved oxygen, $\mathrm{mg} / \mathrm{L}$} & \multicolumn{8}{|c|}{ Ortho-phosphorus, mg/L } & \multicolumn{8}{|c|}{ Ammonia, $\mathrm{mg} / \mathrm{L}$} \\
\hline & \multicolumn{4}{|c|}{ base case } & \multicolumn{4}{|c|}{ recirculation } & \multicolumn{4}{|c|}{ base case } & \multicolumn{4}{|c|}{ recirculation } & \multicolumn{4}{|c|}{ base case } & \multicolumn{4}{|c|}{ recirculation } \\
\hline & 06 & 07 & 08 & 09 & 06 & 07 & 08 & 09 & 06 & 07 & 08 & 09 & 06 & 07 & 08 & 09 & 06 & 07 & 08 & 09 & 06 & 07 & 08 & 09 \\
\hline Jan & 12.2 & 10.3 & 9.1 & 10.0 & 12.2 & 10.3 & 9.2 & 10.2 & 0.07 & 0.06 & 0.05 & 0.06 & 0.06 & 0.06 & 0.05 & 0.06 & 0.60 & 0.88 & 0.94 & 1.22 & 0.60 & 0.89 & 0.97 & 1.25 \\
\hline Feb & 11.9 & 9.9 & 8.2 & 10.5 & 11.9 & 10.0 & 8.4 & 10.7 & 0.10 & 0.07 & 0.07 & 0.06 & 0.09 & 0.06 & 0.06 & 0.06 & 0.35 & 0.70 & 0.99 & 0.80 & 0.35 & 0.71 & 1.04 & 0.85 \\
\hline Mar & 11.2 & 9.7 & 8.5 & 9.7 & 11.2 & 9.8 & 8.6 & 9.7 & 0.11 & 0.06 & 0.12 & 0.10 & 0.10 & 0.05 & 0.12 & 0.10 & 0.14 & 0.34 & 0.71 & 0.41 & 0.13 & 0.34 & 0.73 & 0.42 \\
\hline Apr & 9.5 & 9.1 & 10.1 & 8.9 & 9.5 & 9.2 & 10.0 & 9.0 & 0.08 & 0.05 & 0.04 & 0.06 & 0.08 & 0.04 & 0.03 & 0.06 & 0.12 & 0.14 & 0.21 & 0.15 & 0.12 & 0.14 & 0.21 & 0.14 \\
\hline May & 8.4 & 8.2 & 8.5 & 8.0 & 8.4 & 8.6 & 8.3 & 8.2 & 0.06 & 0.07 & 0.07 & 0.07 & 0.05 & 0.05 & 0.05 & 0.05 & 0.12 & 0.15 & 0.14 & 0.14 & 0.10 & 0.11 & 0.11 & 0.13 \\
\hline Jun & 8.3 & 9.3 & 7.6 & 6.8 & 8.5 & 9.6 & 7.8 & 7.0 & 0.07 & 0.07 & 0.07 & 0.08 & 0.05 & 0.05 & 0.06 & 0.06 & 0.17 & 0.18 & 0.14 & 0.24 & 0.15 & 0.16 & 0.13 & 0.23 \\
\hline Jul & 3.7 & 3.8 & 2.6 & 2.5 & 3.7 & 3.8 & 2.5 & 2.4 & 0.12 & 0.14 & 0.09 & 0.10 & 0.11 & 0.13 & 0.07 & 0.08 & 0.62 & 0.94 & 0.60 & 0.55 & 0.61 & 1.00 & 0.62 & 0.56 \\
\hline Aug & 3.6 & 3.4 & 1.4 & 1.5 & 3.6 & 3.3 & 1.3 & 1.4 & 0.13 & 0.18 & 0.13 & 0.11 & 0.11 & 0.16 & 0.12 & 0.10 & 0.58 & 0.85 & 0.78 & 0.64 & 0.62 & 0.86 & 0.80 & 0.66 \\
\hline Sep & 3.2 & 3.3 & 1.8 & 1.4 & 3.1 & 3.2 & 1.6 & 1.3 & 0.13 & 0.16 & 0.12 & 0.10 & 0.13 & 0.16 & 0.12 & 0.09 & 0.64 & 0.77 & 0.62 & 0.63 & 0.69 & 0.77 & 0.62 & 0.65 \\
\hline Oct & 3.3 & 5.8 & 2.9 & 2.5 & 3.2 & 5.7 & 2.7 & 2.3 & 0.12 & 0.10 & 0.12 & 0.09 & 0.12 & 0.11 & 0.12 & 0.09 & 0.64 & 0.51 & 0.53 & 0.60 & 0.66 & 0.52 & 0.52 & 0.61 \\
\hline Nov & 7.9 & 7.4 & 6.4 & 7.7 & 7.7 & 7.4 & 6.3 & 7.6 & 0.09 & 0.06 & 0.08 & 0.04 & 0.09 & 0.06 & 0.08 & 0.04 & 0.70 & 0.71 & 1.06 & 0.78 & 0.72 & 0.71 & 1.07 & 0.79 \\
\hline Dec & 9.6 & 10.5 & 9.5 & 9.7 & 9.6 & 10.6 & 9.5 & 9.7 & 0.09 & 0.05 & 0.06 & 0.03 & 0.09 & 0.04 & 0.06 & 0.03 & 0.75 & 0.97 & 1.30 & 0.74 & 0.76 & 0.98 & 1.30 & 0.76 \\
\hline
\end{tabular}




\begin{tabular}{|c|c|c|c|c|c|c|c|c|c|c|c|c|c|c|c|c|c|c|c|c|c|c|c|c|}
\hline & \multicolumn{8}{|c|}{ Nitrate, $\mathrm{mg} / \mathrm{L}$} & \multicolumn{8}{|c|}{ Dissolved organic carbon, $\mathrm{mg} / \mathrm{L}$} & \multicolumn{8}{|c|}{ Particulate organic carbon, $\mathrm{mg} / \mathrm{L}$} \\
\hline & \multicolumn{4}{|c|}{ base case } & \multicolumn{4}{|c|}{ recirculation } & \multicolumn{4}{|c|}{ base case } & \multicolumn{4}{|c|}{ recirculation } & \multicolumn{4}{|c|}{ base case } & \multicolumn{4}{|c|}{ recirculation } \\
\hline & 06 & 07 & 08 & 09 & 06 & 07 & 08 & 09 & 06 & 07 & 08 & 09 & 06 & 07 & 08 & 09 & 06 & 07 & 08 & 09 & 06 & 07 & 08 & 09 \\
\hline Jan & 0.36 & 0.45 & 0.49 & 0.41 & 0.36 & 0.39 & 0.45 & 0.38 & 6.1 & 5.9 & 6.1 & 6.0 & 5.9 & 5.2 & 5.2 & 5.2 & 0.6 & 0.5 & 0.4 & 0.6 & 0.6 & 0.4 & 0.3 & 0.5 \\
\hline Feb & 0.32 & 0.45 & 0.46 & 0.33 & 0.32 & 0.40 & 0.44 & 0.29 & 7.4 & 6.7 & 7.2 & 7.9 & 7.2 & 5.7 & 6.3 & 6.2 & 0.8 & 0.6 & 0.8 & 0.9 & 0.8 & 0.5 & 0.6 & 0.6 \\
\hline Mar & 0.24 & 0.31 & 0.49 & 0.27 & 0.23 & 0.31 & 0.50 & 0.27 & 8.3 & 6.9 & 10.6 & 10.3 & 7.8 & 6.3 & 10.2 & 10.0 & 1.1 & 1.2 & 2.1 & 1.4 & 1.0 & 1.1 & 2.0 & 1.4 \\
\hline Apr & 0.20 & 0.22 & 0.13 & 0.08 & 0.20 & 0.22 & 0.13 & 0.08 & 7.5 & 7.4 & 7.2 & 8.3 & 7.4 & 7.2 & 6.8 & 7.7 & 1.4 & 1.4 & 2.2 & 1.5 & 1.4 & 1.4 & 2.1 & 1.4 \\
\hline May & 0.06 & 0.11 & 0.07 & 0.05 & 0.05 & 0.10 & 0.07 & 0.04 & 8.1 & 9.0 & 8.6 & 8.0 & 7.6 & 6.8 & 7.3 & 6.9 & 1.1 & 1.1 & 1.5 & 1.7 & 1.0 & 1.1 & 1.2 & 1.5 \\
\hline Jun & 0.04 & 0.06 & 0.06 & 0.06 & 0.04 & 0.05 & 0.06 & 0.06 & 7.9 & 8.9 & 8.7 & 7.7 & 7.3 & 7.3 & 7.5 & 6.4 & 1.9 & 1.9 & 2.1 & 2.2 & 1.8 & 1.9 & 2.0 & 2.1 \\
\hline Jul & 0.03 & 0.03 & 0.03 & 0.03 & 0.03 & 0.03 & 0.02 & 0.03 & 10.6 & 10.7 & 9.3 & 8.7 & 9.9 & 9.8 & 8.4 & 7.8 & 2.6 & 3.6 & 3.3 & 3.7 & 2.6 & 3.7 & 3.4 & 3.9 \\
\hline Aug & 0.04 & 0.03 & 0.01 & 0.01 & 0.04 & 0.03 & 0.01 & 0.01 & 12.1 & 12.8 & 11.0 & 8.8 & 11.2 & 12.2 & 10.3 & 8.1 & 1.9 & 2.5 & 3.9 & 3.6 & 1.9 & 2.5 & 4.2 & 3.8 \\
\hline Sep & 0.04 & 0.04 & 0.02 & 0.01 & 0.04 & 0.04 & 0.01 & 0.01 & 11.6 & 13.1 & 11.2 & 8.8 & 11.2 & 12.7 & 10.6 & 8.0 & 1.9 & 1.9 & 2.2 & 3.2 & 1.9 & 1.9 & 2.3 & 3.4 \\
\hline Oct & 0.09 & 0.14 & 0.08 & 0.09 & 0.09 & 0.13 & 0.07 & 0.09 & 11.0 & 10.8 & 10.3 & 8.1 & 10.8 & 10.7 & 10.1 & 7.9 & 1.5 & 1.1 & 2.0 & 2.7 & 1.5 & 1.1 & 2.1 & 2.7 \\
\hline Nov & 0.26 & 0.30 & 0.22 & 0.31 & 0.26 & 0.29 & 0.21 & 0.31 & 8.7 & 8.3 & 8.9 & 7.7 & 8.6 & 8.2 & 8.7 & 7.6 & 0.9 & 0.5 & 1.3 & 1.2 & 0.8 & 0.5 & 1.3 & 1.2 \\
\hline Dec & 0.45 & 0.40 & 0.40 & 0.33 & 0.43 & 0.38 & 0.38 & 0.32 & 6.8 & 6.5 & 6.7 & 6.6 & 6.6 & 6.2 & 6.4 & 6.4 & 0.5 & 0.3 & 0.5 & 0.5 & 0.4 & 0.2 & 0.5 & 0.4 \\
\hline
\end{tabular}

\begin{tabular}{|c|c|c|c|c|c|c|c|c|c|c|c|c|c|c|c|c|}
\hline & \multicolumn{8}{|c|}{ Algae, in mg/L } & \multicolumn{8}{|c|}{$\mathrm{pH}$, in standard units } \\
\hline & \multicolumn{4}{|c|}{ base case } & \multicolumn{4}{|c|}{ recirculation } & \multicolumn{4}{|c|}{ base case } & \multicolumn{4}{|c|}{ recirculation } \\
\hline & 06 & 07 & 08 & 09 & 06 & 07 & 08 & 09 & 06 & 07 & 08 & 09 & 06 & 07 & 08 & 09 \\
\hline Jan & 0.07 & 0.06 & 0.12 & 0.10 & 0.07 & 0.06 & 0.13 & 0.10 & 7.9 & 7.6 & 7.4 & 7.7 & 7.8 & 7.6 & 7.4 & 7.7 \\
\hline Feb & 0.07 & 0.06 & 0.14 & 0.07 & 0.07 & 0.06 & 0.15 & 0.07 & 8.6 & 7.7 & 7.4 & 7.9 & 8.7 & 7.8 & 7.4 & 8.0 \\
\hline Mar & 0.23 & 0.14 & 0.30 & 0.19 & 0.22 & 0.13 & 0.31 & 0.17 & 8.4 & 7.9 & 7.6 & 8.0 & 8.4 & 7.9 & 7.6 & 8.0 \\
\hline Apr & 0.86 & 0.51 & 1.00 & 0.62 & 0.85 & 0.51 & 0.99 & 0.61 & 8.0 & 8.0 & 8.4 & 8.0 & 8.0 & 8.0 & 8.4 & 8.0 \\
\hline May & 0.64 & 0.42 & 0.43 & 0.60 & 0.65 & 0.41 & 0.43 & 0.59 & 8.2 & 8.3 & 8.3 & 8.1 & 8.1 & 8.4 & 8.2 & 8.1 \\
\hline Jun & 1.52 & 0.71 & 0.57 & 0.67 & 1.45 & 0.62 & 0.57 & 0.67 & 8.4 & 8.8 & 8.6 & 8.6 & 8.4 & 9.0 & 8.6 & 8.7 \\
\hline Jul & 1.15 & 0.99 & 0.65 & 0.46 & 1.28 & 1.12 & 0.66 & 0.48 & 8.4 & 8.4 & 8.8 & 7.9 & 8.5 & 8.5 & 9.0 & 7.9 \\
\hline Aug & 0.54 & 0.55 & 0.41 & 0.38 & 0.54 & 0.57 & 0.42 & 0.38 & 7.7 & 7.6 & 7.6 & 7.7 & 7.7 & 7.6 & 7.7 & 7.7 \\
\hline Sep & 0.69 & 0.42 & 0.42 & 0.36 & 0.69 & 0.42 & 0.44 & 0.37 & 8.0 & 7.5 & 7.4 & 7.6 & 8.1 & 7.5 & 7.4 & 7.7 \\
\hline Oct & 0.90 & 0.51 & 0.68 & 0.36 & 0.92 & 0.51 & 0.69 & 0.36 & 7.6 & 7.6 & 7.5 & 7.2 & 7.6 & 7.6 & 7.4 & 7.2 \\
\hline Nov & 0.44 & 0.18 & 0.24 & 0.11 & 0.47 & 0.19 & 0.24 & 0.11 & 7.5 & 7.5 & 7.5 & 7.5 & 7.5 & 7.5 & 7.4 & 7.5 \\
\hline Dec & 0.11 & 0.07 & 0.08 & 0.07 & 0.11 & 0.07 & 0.08 & 0.07 & 7.6 & 7.7 & 7.7 & 7.6 & 7.6 & 7.7 & 7.7 & 7.6 \\
\hline
\end{tabular}


This page is intentially blank. 
Back cover: Aerial view of the Klamath River looking southwest from Miller Island (lower right), past the confluence with the Klamath Straits Drain, and downstream to Keno (top center). (Photograph by Mike Deas, May 21, 2014) 


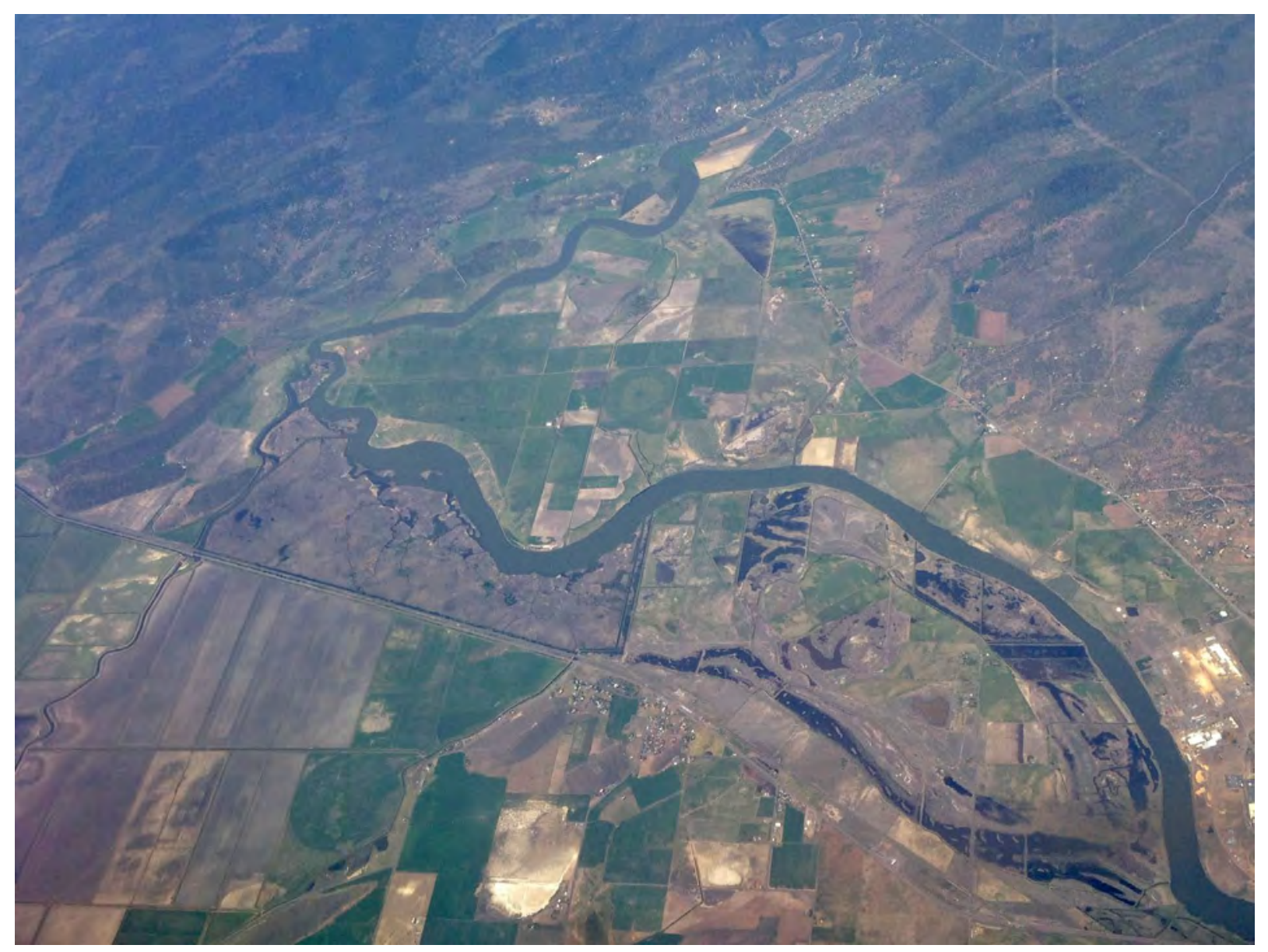

